GUILHERME MAFRA MACHADO

ANÁLISE POR ELEMENTOS FINITOS DE

MACIÇOS ESCAVADOS POR TÚNEIS 
GUILHERME MAFRA MACHADO

\section{ANÁLISE POR ELEMENTOS FINITOS DE MACIÇOS ESCAVADOS POR TÚNEIS}

Dissertação apresentada à Escola Politécnica da Universidade de São Paulo para obtenção do título de Mestre em Engenharia.

Área de Concentração: Engenharia Geotécnica

Orientador: Prof. Dr. Marcos Massao Futai 
Este exemplar foi revisado e alterado em relação à versão original, sob responsabilidade única do autor e com a anuência de seu orientador.

São Paulo, de outubro de 2011.

Assinatura do autor

Assinatura do orientador

FICHA CATALOGRÁFICA

Mafra Machado, Guilherme

Análise por elementos finitos de maciços escavados por túneis / G. Mafra Machado. -- ed.rev. -- São Paulo, 2011. $102 \mathrm{p}$.

Dissertação (Mestrado) - Escola Politécnica da Universidade de São Paulo. Departamento de Engenharia de Estruturas e Geotécnica.

1.Túneis 2.Análise numérica 3.Método dos elementos finitos I.Universidade de São Paulo. Escola Politécnica. Departamento de Engenharia de Estruturas e Geotécnica II.t. 


\section{AGRADECIMENTOS}

Ao Professor Waldemar Coelho Hachich pela orientação eficiente, pelo exemplo e amizade.

Ao Professor Marcos Massao Futai pelas valiosas opiniões, pela confiança e amizade.

Ao Dr. Arsênio Negro Júnior, por ter contribuído na definição dos rumos da pesquisa e pela participação enriquecedora no Exame de Qualificação.

A todos os professores e colegas do curso.

Ao Professor David M. Potts e à Dra. Lidija Zdravkovic, pela oportunidade oferecida e pela assistência no período que permaneci no Imperial College. A todos os colegas do Imperial, especialmente aos pesquisadores David Taborda, Nunzio Losacco, Nina Jurecic, David Abadias, Aikaterini Tsiampousi e Siya Rimoy.

Ao Professor Jorge de Almeida e Sousa, da Universidade de Coimbra, ao engenheiro Pedro Teodoro França e à Companhia do Metropolitano de São Paulo, nomeadamente aos engenheiros Marco Aurélio da Silva, Argimiro Alvarez Ferreira e Francisco Ribeiro Neto, por terem gentilmente cedido informações sobre o Túnel Paraíso.

À Janete Santana, do Programa de Pós-Graduação, por toda assistência e atenção.

À Escola Politécnica da USP, pela formação e pelas portas sempre abertas.

Aos meus pais, Elisa e Cyrillo, e a minha irmã Soraia, por todo amor e apoio incondicional. Aos meus familiares e amigos, por todo carinho e apoio. 


\section{RESUMO}

O presente trabalho de pesquisa aborda a aplicação de análise por elementos finitos a maciços escavados por túneis, revisando relevantes estudos sobre análise numérica deste tipo de obra e realizando modelagem numérica própria, bi e tridimensional, voltada ao caso do Túnel Paraíso do Metrô de São Paulo (obra com dados de instrumentação e de ensaios), com uso do consagrado programa de elementos finitos Imperial College Finite Element Program (ICFEP), desenvolvido nos últimos trinta anos no Imperial College de Londres.

Dentre os modelos constitutivos adotados nestas análises, destaca-se o Cinemático com Duas Superfícies Modificado do Imperial College, modelo elasto-plástico com endurecimento cinemático e isotrópico, baseado no estado crítico, com grande capacidade de representar as características de rigidez de argilas sobreadensadas (como são as argilas da região do Túnel Paraíso), cujas principais características são levantadas através de revisão bibliográfica.

Da observação da etapa de reprodução numérica de ensaios e dos resultados conseguidos com as análises da escavação do túnel, são feitas considerações sobre o desempenho de todos os modelos constitutivos adotados (além do Cinemático com Duas Superfícies Modificado, o Cam-Clay Modificado e o elasto perfeitamente plástico com critério de ruptura de MohrColoumb), bem como sobre a performance dos modelos numéricos desenvolvidos.

Palavras-chave: Túneis. Análise Numérica. Elementos Finitos. Modelo Constitutivo ElastoPlástico. Estado Crítico. 


\begin{abstract}
This research approaches the application of finite element analysis to tunnel excavation, making a survey of some numerical relevant studies of this kind of construction and performing a range of plane-strain and three-dimensional analyses, focused on the Paraíso Tunnel from Sao Paulo Underground (with field instrumentation and lab tests), using a powerful finite element program, the Imperial College Finite Element Program (ICFEP), developed in the last thirty years at Imperial College London.
\end{abstract}

Among the constitutive models adopted in those analyses, it is highlighted the Modified Two Surfaces Kinematic from Imperial College, a elasto-plastic model with kinematic and isotropic hardening, based on the critical state, with great ability to represent the pre-failure stiffness of overconsolidated clays (as are the clays around Paraíso Tunnel), whose main features are raised through a literature survey.

From the results of numerical simulation of lab tests and from the predictions of the tunnelling analyses, it is discussed the performance of all constitutive models adopted (including Modified Cam-Clay and elastic perfectly plastic model with Mohr-Coloumb failure criterion) and of the numerical models developed.

Keywords: Tunnels. Numerical Analysis. Finite Element. Elasto-Plastic Constitutive Model. Critical State. 


\section{LISTA DE FIGURAS}

Figura 1 Reprodução numérica do ensaio edométrico e a conseqüente boa representação dos deslocamentos verticais em profundidade na cobertura do túnel (FRANÇA, 2006)

Figura 2 Deslocamentos horizontais em profundidade obtidos com o modelo elasto perfeitamente plástico e com o Cam-Clay Modificado (SILVA, 2008).

Figura 3 Mapeamento segundo zonas com predominância de determinada trajetória de tensão conforme evolui a escavação (CECÍLIO JR., 2009). .25

Figura 4 Geometria da seção - medidas em m (SILVA, 2008). .26

Figura 5 Localização da obra (adaptada de FRANÇA, 2006) ............................................2

Figura 6 Perfil geotécnico do local (adaptada de SILVA, 2008), ...................................... 28

Figura 7 Indicação do trecho analisado (adaptada de FRANÇA, 2006). ............................29

Figura 8 Representação do processo construtivo (adaptada de SILVA, 2008).................... 30

Figura 9 Vista em planta da seção instrumentada $\mathrm{S} \varnothing 2$ - medidas em cm (PARREIRA,

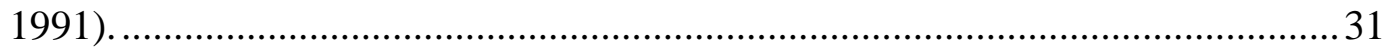

Figura 10 Vista em corte da seção instrumentada SØ2 (adaptada de PARREIRA, 1991).... 32

Figura 11 Bacia de recalques superficiais (SOUSA, 1998). 33

Figura 12 Recalques em profundidade - ext. magnéticos a $1 \mathrm{~m}$ do eixo do túnel (SOUSA, 1998).

Figura 13 Recalques em profundidade - ext. magnéticos a $6 \mathrm{~m}$ do eixo do túnel (SOUSA, 1998).

Figura 14 Equação propondo deslocamentos verticais $\left(S_{\mathrm{v}}\right)$ crescentes com a profundidade na cobertura do túnel (MAIR et al, 1993). $\mathrm{V}_{\mathrm{L}}$ é a perda de volume por unidade de comprimento.

Figura 15 Deslocamentos horizontais - inclinômetro a $6 \mathrm{~m}$ do eixo do túnel (SOUSA, 1998).

Figura 16 Recalques à superfície conforme avança a escavação - placa de recalque superficial alinhada com o eixo do túnel (SOUSA, 1998). .36

Figura 17 Perfil geotécnico do Poço Experimental Gazeta (PARREIRA, 1991)................. 37

Figura 18 Ensaio triaxial drenado de compressão por carregamento - AP1 $\left(\sigma_{3}=49 \mathrm{kPa}\right) \ldots . .38$

Figura 19 Ensaio triaxial drenado de compressão por carregamento - AP2 $\left(\sigma_{3}=98,1 \mathrm{kPa}\right) \ldots 39$ 
Figura 20 Ensaio triaxial drenado de compressão por carregamento - AV ( $\left.\sigma_{3}=196,1 \mathrm{kPa}\right) . .40$

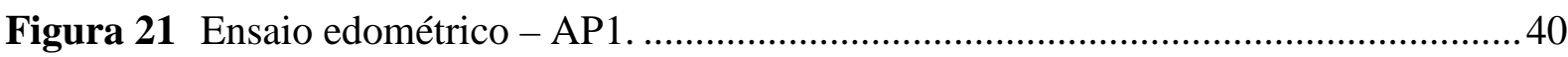

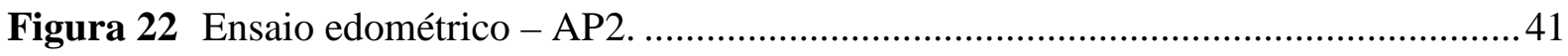

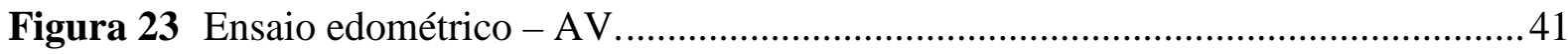

Figura 24 Espaço $v-\ln p$ ': linha de compressão isotrópica (isotropic compression line), linha de descompressão (swelling line) e projeção da linha do estado crítico (critical state line).

Figura 25 Espaço q-p': projeção da linha do estado crítico (critical state line) e projeção da superfície de plastificação (yield surface).

Figura 26 Superfície limite de estado (state boundary surface). 46

Figura 27 Projeção da superfície de plastificação cinemática (yield surface) e da superfície limite (bounding surface) no espaço $q-p^{\prime}$. 48

Figura 28 Indicação do vetor $\beta$. 49

Figura 29 Evolução simultânea das duas superfícies. 51

Figura 30 Reprodução numérica do ensaio triaxial drenado de compressão por carregamento - AP1 $\left(\sigma_{3}=49 \mathrm{kPa}\right)-$ Mohr-Coloumb I. 54

Figura 31 Variação do módulo de rigidez cisalhante conseguida com a reprodução numérica do ensaio triaxial acima - AP1 - Mohr-Coloumb I.

Figura 32 Reprodução numérica do ensaio triaxial drenado de compressão por carregamento - AP2 $\left(\sigma_{3}=98,1 \mathrm{kPa}\right)-$ Mohr-Coloumb I.

Figura 33 Variação do módulo de rigidez cisalhante conseguida com a reprodução numérica do ensaio triaxial acima - AP2 - Mohr-Coloumb I. 55

Figura 34 Reprodução numérica do ensaio triaxial drenado de compressão por carregamento - AV $\left(\sigma_{3}=196,1 \mathrm{kPa}\right)-$ Mohr-Coloumb I. 56

Figura 35 Variação do módulo de rigidez cisalhante conseguida com a reprodução numérica do ensaio triaxial acima - AV - Mohr-Coloumb I. 56

Figura 36 Reprodução numérica do ensaio triaxial drenado de compressão por carregamento - AP1 $\left(\sigma_{3}=49 \mathrm{kPa}\right)-$ Mohr-Coloumb II 58

Figura 37 Reprodução numérica do ensaio triaxial drenado de compressão por carregamento - AP2 $\left(\sigma_{3}=98,1 \mathrm{kPa}\right)-$ Mohr-Coloumb II.

Figura 38 Reprodução numérica do ensaio triaxial drenado de compressão por carregamento - AV $\left(\sigma_{3}=196,1 \mathrm{kPa}\right)-$ Mohr-Coloumb II. 60

Figura 39 Obtenção dos parâmetros $N^{*}, \lambda^{*}$ e $\kappa^{*}$. 61 
Figura 40 Obtenção do parâmetro $M$.

Figura 41 Obtenção da rigidez cisalhante elástica $(G)$.

Figura 42 Reprodução numérica do ensaio triaxial drenado de compressão por carregamento - AP1 $\left(\sigma_{3}=49 \mathrm{kPa}\right)$ - Cam-Clay Modificado.

Figura 43 Variação do módulo de rigidez cisalhante conseguida com a reprodução numérica do ensaio triaxial acima - AP1 - Cam-Clay Modificado.

Figura 44 Reprodução numérica do ensaio edométrico - AP1 - Cam-Clay Modificado.

Figura 45 Reprodução numérica do ensaio triaxial drenado de compressão por carregamento - AP2 $\left(\sigma_{3}=98,1 \mathrm{kPa}\right)$ - Cam-Clay Modificado.

Figura 46 Variação do módulo de rigidez cisalhante conseguida com a reprodução numérica do ensaio triaxial acima - AP2 - Cam-Clay Modificado.

Figura 47 Reprodução numérica do ensaio edométrico - AP2 - Cam-Clay Modificado.

Figura 48 Reprodução numérica do ensaio triaxial drenado de compressão por carregamento - $\operatorname{AV}\left(\sigma_{3}=196,1 \mathrm{kPa}\right)$ - Cam-Clay Modificado.

Figura 49 Variação do módulo de rigidez cisalhante conseguida com a reprodução numérica do ensaio triaxial acima - AV - Cam-Clay Modificado. .68

Figura 50 Reprodução numérica do ensaio edométrico - AV - Cam-Clay Modificado.

Figura 51 Reprodução numérica do ensaio triaxial drenado de compressão por carregamento - AP1 $\left(\sigma_{3}=49 \mathrm{kPa}\right)$ - Cinemático com Duas Superfícies Modificado do IC.

Figura 52 Variação do módulo de rigidez cisalhante conseguida com a reprodução numérica do ensaio triaxial acima - AP1 - Cinemático com Duas Superfícies Modificado do IC.

Figura 53 Reprodução numérica do ensaio edométrico - AP1 - Cinemático com Duas Superfícies Modificado do IC.

Figura 54 Reprodução numérica do ensaio triaxial drenado de compressão por carregamento - AP2 $\left(\sigma_{3}=98,1 \mathrm{kPa}\right)$ - Cinemático com Duas Superfícies Modificado do IC. ..... 72

Figura 55 Variação do módulo de rigidez cisalhante conseguida com a reprodução numérica do ensaio triaxial acima - AP2 - Cinemático com Duas Superfícies Modificado do IC. .72

Figura 56 Reprodução numérica do ensaio edométrico - AP2 - Cinemático com Duas Superfícies Modificado do IC.

Figura 57 Reprodução numérica do ensaio triaxial drenado de compressão por carregamento - AV $\left(\sigma_{3}=196,1 \mathrm{kPa}\right)$ - Cinemático com Duas Superfícies Modificado do IC...... 74 
Figura 58 Variação do módulo de rigidez cisalhante conseguida com a reprodução numérica do ensaio triaxial acima - AV - Cinemático com Duas Superfícies Modificado do IC.

Figura 59 Reprodução numérica do ensaio edométrico - AV - Cinemático com Duas Superfícies Modificado do IC

Figura 60 De cima para baixo: malha 3D vista em perspectiva (situação representa um passo de avanço intermediário); seção transversal da malha; seção longitudinal. .78

Figura 61 Detalhe da parcialização reproduzida. .79

Figura 62 Bacias de recalques superficiais - análises numéricas 3D x campo. 80

Figura 63 Recalques em profundidade - extensômetros magnéticos a $1 \mathrm{~m}$ do eixo do túnel análises numéricas 3D x campo.

Figura 64 Recalques em profundidade - extensômetros magnéticos a $6 \mathrm{~m}$ do eixo do túnel análises numéricas 3D x campo. 81

Figura 65 Deslocamentos horizontais - inclinômetro a $6 \mathrm{~m}$ do eixo do túnel - análises numéricas 3D x campo.

Figura 66 Recalques à superfície conforme avança a escavação - placa de recalque superficial alinhada com o eixo do túnel - análises numéricas 3D x campo. ........82

Figura 67 Bacias de recalques superficiais - análises numéricas 3D x campo. 84

Figura 68 Recalques em profundidade - extensômetros magnéticos a 1m do eixo do túnel análises numéricas 3D x campo.

Figura 69 Recalques em profundidade - extensômetros magnéticos a $6 \mathrm{~m}$ do eixo do túnel análises numéricas 3D x campo.

Figura 70 Deslocamentos horizontais - inclinômetro a $6 \mathrm{~m}$ do eixo do túnel - análises numéricas 3D x campo.

Figura 71 Recalques à superfície conforme avança a escavação - placa de recalque superficial alinhada com o eixo do túnel - análises numéricas 3D x campo. 86

Figura 72 Pontos no plano da seção instrumentada do modelo numérico cujas tensões foram monitoradas.

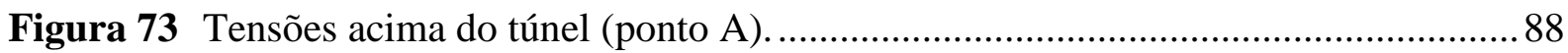

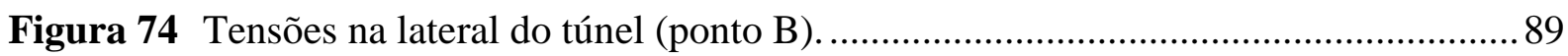

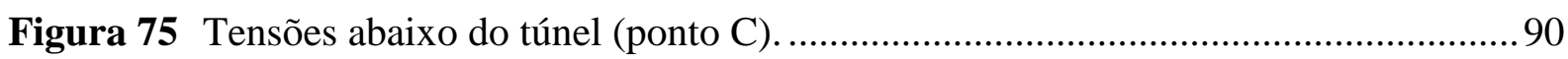

Figura 76 Bacias de recalques superficiais - análise 2D $x$ análise 3D. ............................. 92

Figura 77 Recalques em profundidade - extensômetros magnéticos a 1m do eixo do túnel análise 2D $\mathrm{x}$ análise 3D. 
Figura 78 Recalques em profundidade - extensômetros magnéticos a $6 \mathrm{~m}$ do eixo do túnel análise 2D $\mathrm{x}$ análise 3D.

Figura 79 Deslocamentos horizontais - inclinômetro a $6 \mathrm{~m}$ do eixo do túnel - análise $2 \mathrm{D} x$ análise 3D.

Figura 80 Bacias de recalques superficiais - análise numérica 2D x campo. 94

Figura 81 Recalques em profundidade - extensômetros magnéticos a 1m do eixo do túnel análise numérica $2 \mathrm{D}$ x campo.

Figura 82 Recalques em profundidade - extensômetros magnéticos a $6 \mathrm{~m}$ do eixo do túnel análise numérica $2 \mathrm{D}$ x campo.

Figura 83 Deslocamentos horizontais - inclinômetro a $6 \mathrm{~m}$ do eixo do túnel - análise numérica 2D x campo. 96 


\section{LISTA DE TABELAS}

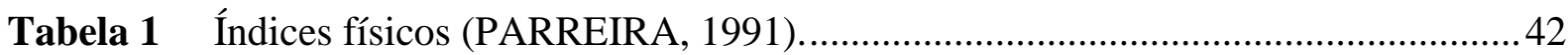

Tabela 2 Parâmetros de partida (PARREIRA, 1991) .............................................................53

Tabela 3 Parâmetros definitivos - Mohr-Coloumb I........................................................... 53

Tabela 4 Parâmetros definitivos - Mohr-Coloumb II. ........................................................ 57

Tabela 5 Parâmetros do modelo Cam-Clay Modificado..................................................... 63

Tabela 6 Parâmetros do modelo Cinemático com Duas Superfícies Modificado do IC.....70 


\section{LISTA DE SÍMBOLOS}

\section{Alfabeto Latino}

A

$b$

$c^{\prime}$

e

$e_{0}$

$E_{0}$

$E_{50}$

G

K

$K_{0}$

M

$N$

$N^{*}$

$p^{\prime}$

$\left(p^{\prime}{ }_{\mathrm{a}}, q_{\mathrm{a}}\right)$

$p{ }^{\prime}$

$p^{\prime}{ }^{*}$

$q$

$R$

S

$S_{\mathrm{V}}$

$v$

$v_{\kappa}$

$\mathrm{V}_{\mathrm{L}}$

$w$

módulo de endurecimento

distância entre a superfície de plastificação cinemática e a superfície limite

coesão efetiva

índice de vazios

índice de vazios inicial

módulo tangente inicial

módulo secante correspondente a 50\% da tensão desviadora na ruptura

rigidez cisalhante elástica

rigidez volumétrica elástica

coeficiente de empuxo em repouso

inclinação da linha do estado crítico no espaço $q-p^{\prime}$

volume específico da linha de compressão isotrópica para $p^{\prime}=1 \mathrm{kPa}$

volume específico da linha de compressão do ensaio edométrico para $p^{\prime}=1 \mathrm{kPa}$

tensão efetiva média

centro da superfície de plastificação cinemática

valor da maior tensão efetiva média a que o solo já esteve submetido

tensão efetiva média referente à intersecção da reta $K_{0}$ (trajetória de tensões de um ensaio edométrico) com a superfície limite no espaço $q-p$ '

tensão desviadora

razão entre o tamanho da superfície de plastificação cinemática e o tamanho da superfície limite (determinada experimentalmente durante a reprodução numérica de ensaios)

grau de saturação

deslocamentos verticais

volume específico

volume específico da linha de descompressão para $p^{\prime}=1 \mathrm{kPa}$

perda de volume por unidade de comprimento

teor de umidade 


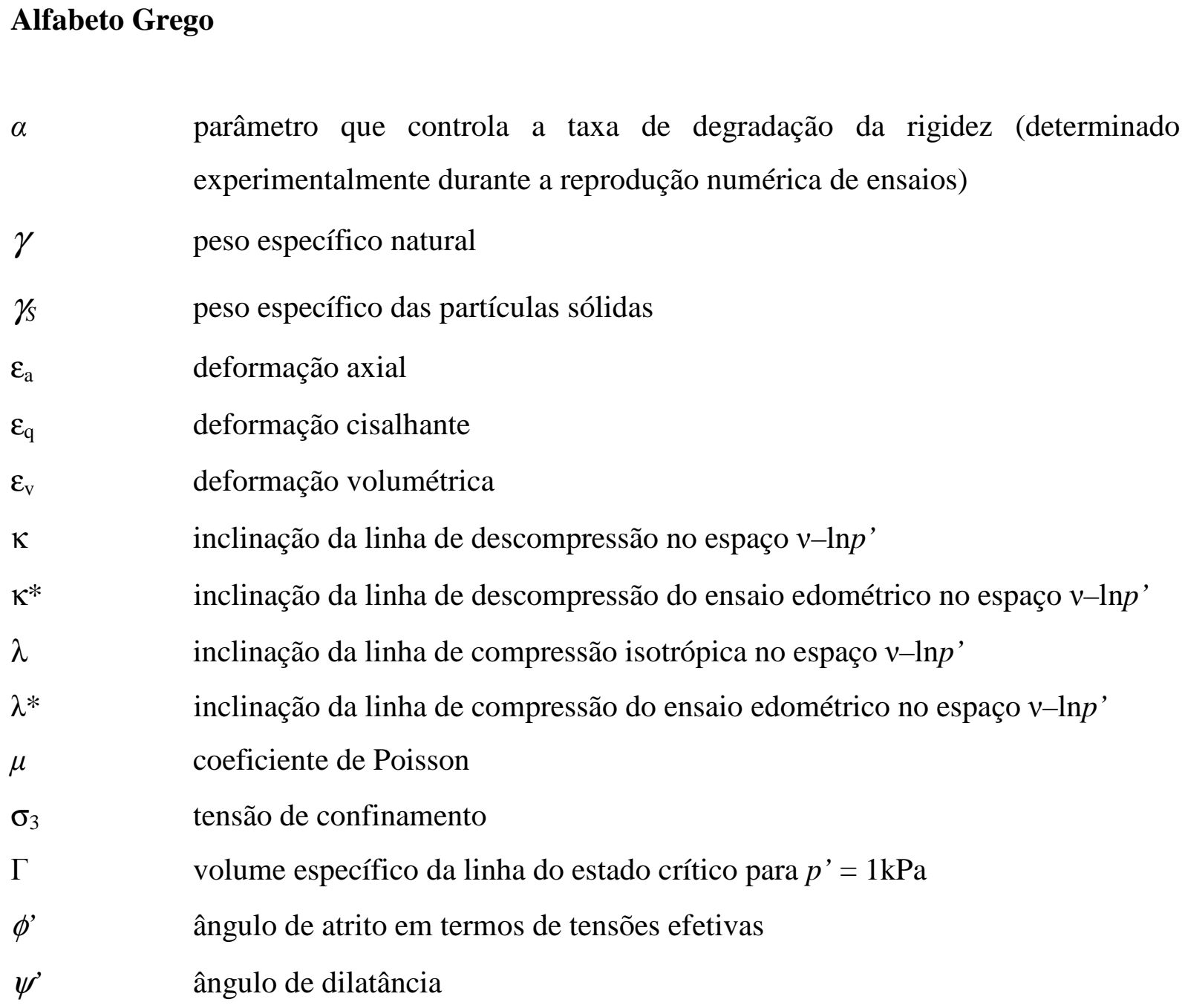

$\alpha$

parâmetro que controla a taxa de degradação da rigidez (determinado experimentalmente durante a reprodução numérica de ensaios)

$\gamma \quad$ peso específico natural

$\gamma_{S} \quad$ peso específico das partículas sólidas

$\varepsilon_{\mathrm{a}} \quad$ deformação axial

$\varepsilon_{\mathrm{q}} \quad$ deformação cisalhante

$\varepsilon_{\mathrm{v}} \quad$ deformação volumétrica

$\kappa \quad$ inclinação da linha de descompressão no espaço $v-\ln p$,

$\kappa^{*}$

inclinação da linha de descompressão do ensaio edométrico no espaço $v-\ln p$ '

$\lambda \quad$ inclinação da linha de compressão isotrópica no espaço $v-\ln p$,

$\lambda^{*} \quad$ inclinação da linha de compressão do ensaio edométrico no espaço $v-\ln p$,

$\mu \quad$ coeficiente de Poisson

$\sigma_{3} \quad$ tensão de confinamento

$\Gamma \quad$ volume específico da linha do estado crítico para $p^{\prime}=1 \mathrm{kPa}$

$\phi$ ângulo de atrito em termos de tensões efetivas

$\psi^{\prime} \quad$ ângulo de dilatância

\section{Abreviações}

AP1 argila porosa média a mole

AP2 argila porosa média a rija

AV argila variegada

IC Imperial College

ICFEP Imperial College Finite Element Program

NATM New Austrian Tunneling Method

OCR razão de sobreadensamento em termos de tensões efetivas médias (obtida pela divisão de $p{ }_{0}$ pelo $p$ ' geostático do solo)

$O C R^{*} \quad$ divisão de $p{ }^{\prime}{ }_{0}^{*}$ pelo $p$ ' geostático do solo 


\section{SUMÁRIO}

1 INTRODUÇÃO

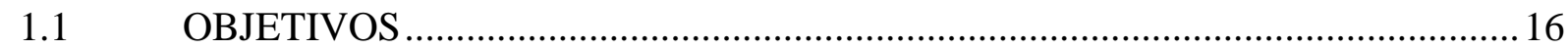

1.2 ESTRUTURAÇÃO DA DISSERTAÇÃO.............................................................. 17

2 MODELAGEM POR ELEMENTOS FINITOS DE MACIÇOS ESCAVADOS POR

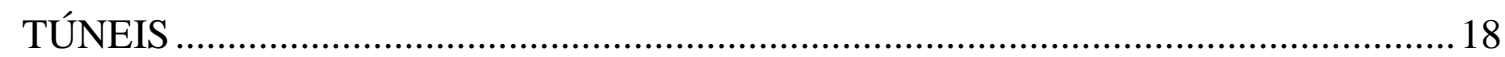

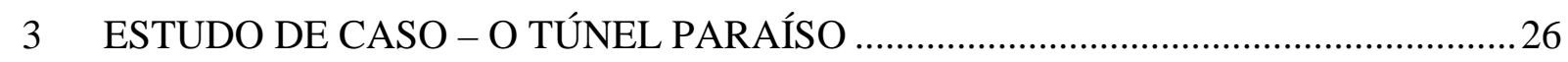

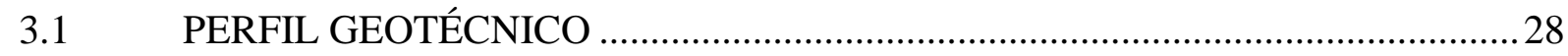

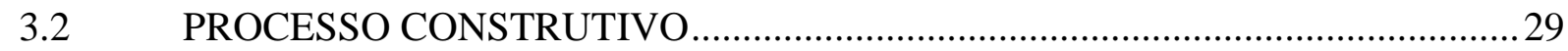

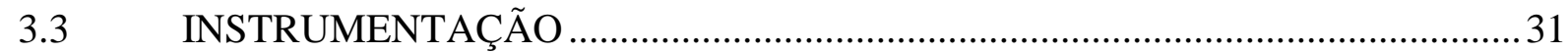

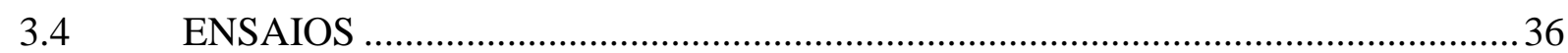

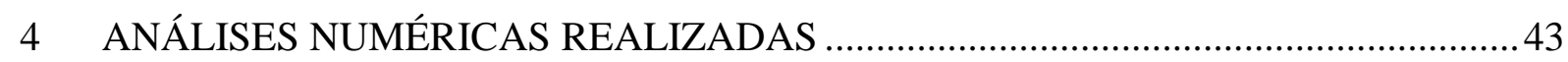

4.1 O MODELO CAM-CLAY MODIFICADO E O CINEMÁTICO COM DUAS SUPERFÍCIES MODIFICADO DO IMPERIAL COLLEGE ....................................4

4.2 OBTENÇÃO DOS PARÂMETROS DOS SOLOS …………………………........52

4.3 MODELOS NUMÉRICOS CONSTRUÍDOS ………………………………....76

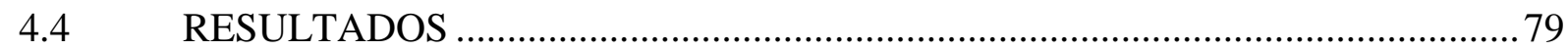

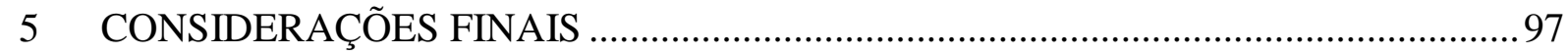

5.1 SUGESTÕES PARA TRABALHOS FUTUROS ...............................................98

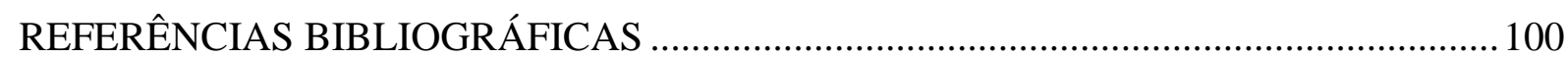




\section{INTRODUÇÃO}

A análise de maciços escavados por túneis através de elementos finitos é uma prática cada vez mais freqüente nos escritórios de engenharia ao longo do mundo, viabilizada pelo avanço da capacidade de processamento dos computadores e impulsionada pela necessidade de se estimar com maior precisão os deslocamentos decorrentes do tunelamento, especialmente em áreas urbanas, onde a superfície do terreno se apresenta densamente ocupada por edificações e estruturas diversas.

O aumento da demanda por este tipo de análise, não somente na área de túneis, mas no meio geotécnico em geral, fomentou o desenvolvimento de inúmeros trabalhos de pesquisa, que geraram avanços inegáveis. Os modelos numéricos, antes exclusivamente bidimensionais, podem atualmente empregar malhas $3 \mathrm{D}$, onde o processo construtivo pode ser reproduzido com fidelidade e a distribuição de cargas geradas pela escavação do túnel se dá integralmente, tanto na transversal quanto na longitudinal, o que significa maior proximidade com a realidade e, portanto, obtenção de resultados mais confiáveis. O mesmo progresso se observa com relação aos modelos constitutivos, que aprimoram gradualmente sua capacidade de representar o aspecto não linear da rigidez dos materiais, bem como a variação da rigidez conforme a solicitação sofrida, possibilitando aumento da qualidade das previsões de deslocamentos.

Estes estudos numéricos prosseguem, no sentido de aprimorar os modelos, verificar sua aplicabilidade e investigar os fatores que possam influenciar em seus resultados, garantindo aos engenheiros geotécnicos mais segurança na utilização de análises por elementos finitos como instrumento de apoio à decisão. 


\subsection{OBJETIVOS}

O objetivo geral deste trabalho de pesquisa é estudar a aplicação de análise por elementos finitos a maciços escavados por túneis, através de revisão da bibliografia existente sobre análises numéricas deste tipo de obra e por meio de modelagem numérica própria, aplicada ao Túnel Paraíso do Metrô de São Paulo, obra da década de oitenta, com dados de ensaios e de instrumentação de campo, adotada como estudo de caso.

Os objetivos específicos consistem em:

- prever, através de modelagem numérica bi e tridimensional, os deslocamentos no maciço decorrentes da escavação do Túnel Paraíso;

- apresentar a experiência da utilização de um programa de elementos finitos consagrado, o ICFEP (Imperial College Finite Element Program), desenvolvido nos últimos trinta anos no Imperial College de Londres e aplicado com sucesso em análise de obras importantes na Europa, com o qual se realizou etapa de reprodução de ensaios (a fim de obtenção de parâmetros) e análises numéricas bi e tridimensionais do Túnel Paraíso, adotando os modelos constitutivos elasto perfeitamente plástico com critério de ruptura de Morh-Coloumb, CamClay Modificado e Cinemático com Duas Superfícies Modificado do Imperial College;

- realizar a revisão bibliográfica do mais sofisticado modelo constitutivo adotado, o Cinemático com Duas Superfícies Modificado do Imperial College, modelo elasto-plástico com endurecimento cinemático e isotrópico, baseado no estado crítico, uma extensão do CamClay Modificado, com grande capacidade de representar as características de rigidez de argilas sobreadensadas, de maneira que suas principais características possam ser compreendidas;

- avaliar, a partir da observação da etapa de reprodução de ensaios e dos resultados conseguidos com as análises da escavação do túnel, o desempenho de cada modelo constitutivo adotado, bem como a performance dos modelos numéricos desenvolvidos. 


\subsection{ESTRUTURAÇÃO DA DISSERTAÇÃO}

A presente dissertação possui, além deste primeiro capítulo introdutório, mais outros quatro capítulos.

O capítulo 2 contém a revisão bibliográfica realizada sobre análises numéricas de escavações de túneis, em que são apresentadas as principais características de relevantes estudos envolvendo modelagem por elementos finitos deste tipo de obra.

No capítulo 3, são dadas informações sobre o caso em estudo, o Túnel Paraíso, tais como localização, geometria, perfil geotécnico, processo construtivo e alguns resultados da campanha de instrumentação e de ensaios.

O capitulo 4 trata da modelagem numérica desenvolvida neste trabalho. Contém informações sobre o programa de elementos finitos utilizado (ICFEP), a revisão bibliográfica dos modelos constitutivos do estado crítico adotados, detalhes do processo de obtenção dos parâmetros dos solos (etapa de reprodução de ensaios) e descrição das características dos modelos numéricos construídos para análise da escavação do túnel, bem como apresenta os resultados obtidos e o confronto destes com os dados de instrumentação de campo.

O capítulo 5, último, é destinado às considerações finais e às sugestões para trabalhos de pesquisa futuros. 


\section{MODELAGEM POR ELEMENTOS FINITOS DE MACIÇOS ESCAVADOS POR TÚNEIS}

Este capítulo apresenta a revisão de relevantes estudos envolvendo análises numéricas de escavações subterrâneas, tanto bi quanto tridimensionais, parte deles com foco na avaliação de modelos numéricos, outros direcionados à verificação do desempenho de modelos constitutivos, a partir dos quais é possível compreender as temáticas recentemente abordadas nesta linha de pesquisa e a importância deste tipo de trabalho investigativo na consagração do método dos elementos finitos como um importante instrumento para a análise de escavações de túneis. Tal revisão bibliográfica serviu ainda para subsidiar o desenvolvimento das análises numéricas deste trabalho.

A começar por Parreira (1991), que realiza um interessante trabalho envolvendo ensaios laboratoriais e análises numéricas bidimensionais. Seu estudo de caso é a escavação do Túnel Paraíso do Metrô de São Paulo, obra com dados de instrumentação, a mesma adotada pelo presente trabalho de pesquisa, sendo o objetivo central o de estudar o desempenho do modelo elasto-plástico de Lade na previsão de deslocamentos devidos à construção de túneis rasos em solo. Vale destacar a completa caracterização dos materiais do local realizada por meio de ensaios de índices físicos, edométricos e triaxiais sob diversas trajetórias de tensão, a reprodução numérica de alguns ensaios triaxiais a fim de obtenção de parâmetros do modelo constitutivo de Lade e a investigação da influência da consideração do pavimento no modelo numérico, que revelou a necessidade de sua inclusão pelo seu impacto nos deslocamentos horizontais. Nas análises bidimensionais, em que escavação foi simulada através de redução gradual da tensão in situ no contorno do túnel, foram adotados, além do modelo constitutivo de Lade, o elástico linear e o elasto perfeitamente plástico com critério de ruptura de MohrColoumb. Os resultados obtidos mostram o benefício da utilização de um modelo elasto plástico com endurecimento como o de Lade, cuja análise alcançou maior concordância com os dados de recalques superficiais e de deslocamentos horizontais em profundidade fornecidos pela instrumentação de campo.

Sousa (1998) apresenta um abrangente estudo dedicado à análise numérica de escavações em maciços terrosos, envolvendo modelagem bi e tridimensional de três casos de obras 
subterrâneas, todas com dados de instrumentação, sendo uma delas o Túnel Paraíso. No que se refere às análises deste túnel, foram adotados o modelo constitutivo de Lade e o elasto perfeitamente plástico com critério de ruptura de Mohr-Coloumb, havendo aproveitamento dos parâmetros definidos por Parreira (1991) para estes dois modelos. As análises tridimensionais, realizadas segundo o método passo-a-passo (step-by-step approach), em que a escavação é modelada por sucessivas remoções dos elementos da frente (Katzenbach \& Breth, 1981), reproduziram com bastante sucesso os deslocamentos do maciço, mesmo quando adotado o modelo elasto perfeitamente plástico, sendo que foi o modelo de Lade aquele que permitiu maior concordância com os dados de recalques superficiais e de deslocamentos verticais em profundidade fornecidos pela instrumentação de campo. Deve salientar-se que houve ajuste do módulo de rigidez inicial do concreto projetado (na fase em que esta estrutura de suporte não se encontrava ainda totalmente fechada), de maneira que o deslocamento à superfície do modelo numérico 3D na linha de eixo do túnel fosse igual ao observado em campo. O valor assim obtido para o módulo de rigidez inicial do concreto projetado foi de apenas $0,6 \mathrm{GPa}$. Ainda com relação à abordagem desta obra do Metrô de São Paulo, vale destacar a explicação apresentada para a ocorrência de peculiares deslocamentos verticais em profundidade na região da cobertura (fornecidos pela instrumentação), maiores nas proximidades da superfície e menores junto à calota do túnel, o contrário do que geralmente se registra na cobertura de um túnel ao fim da escavação. Segundo o autor, esta característica é função do movimento de corpo rígido experimentado pelo bloco de solo situado na cobertura, ocorrido com a passagem e posterior afastamento da frente de escavação, não se verificando nenhuma atenuação dos deslocamentos verticais a partir do contorno da abertura até a superfície, comumente observada em escavações subterrâneas.

França (2006) apresenta outro interessante estudo numérico envolvendo o Túnel Paraíso, voltado à avaliação do desempenho de dois modelos constitutivos na previsão dos deslocamentos ocorridos no maciço em decorrência da escavação. As análises realizadas, todas tridimensionais (método passo-a-passo), empregaram um programa de elementos finitos comercial, o Plaxis 3D Tunnel, utilizado em muitos escritórios de engenharia consultiva pelo mundo. Os modelos constitutivos avaliados foram o elasto perfeitamente plástico com critério de ruptura de Mohr-Coloumb e o Hardening Soil do Plaxis, com plastificação com endurecimento, desenvolvido exclusivamente para o programa. Os resultados obtidos com as análises sugerem que ambos os modelos constitutivos são capazes de reproduzir com boa qualidade os deslocamentos no maciço, mas evidenciam o melhor desempenho do modelo 
Hardening Soil do Plaxis na representação dos deslocamentos verticais em profundidade na região da cobertura do túnel. Destaque para a inclusão no modelo numérico de toda parcialização realizada em obra e para a variação realizada do módulo de rigidez do concreto projetado (módulo de rigidez de 5GPa na fase em que esta estrutura suporte não se encontrava totalmente fechada e igual a 10GPa quando do fechamento da mesma). Vale ainda ressaltar o processo de obtenção dos parâmetros do modelo Hardening Soil do Plaxis, através da reprodução numérica de ensaios edométricos, incluindo a etapa de descarregamento, o que incorpora ao modelo módulos de rigidez distintos para as situações de carregamento e descarregamento, característica esta tida como fundamental para seu sucesso na representação dos peculiares deslocamentos verticais em profundidade na cobertura do túnel (Figura 1).
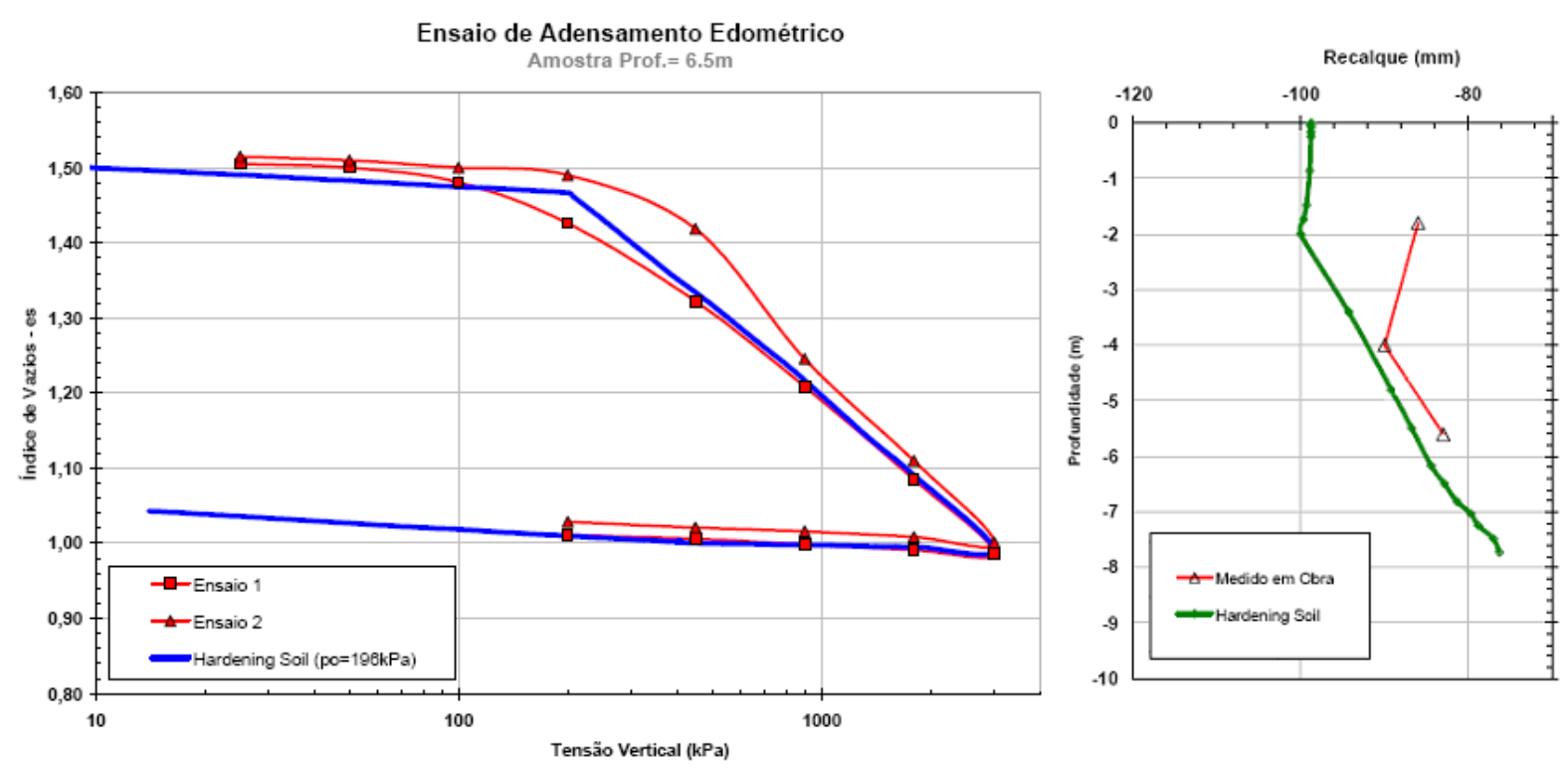

Figura 1 Reprodução numérica do ensaio edométrico e a conseqüente boa representação dos deslocamentos verticais em profundidade na cobertura do túnel (FRANÇA, 2006).

A pesquisa numérica de Silva (2008) busca avaliar a diferença de resultados de análises de escavações subterrâneas adotando dois modelos constitutivos distintos: o elasto perfeitamente plástico com critério de ruptura de Mohr-Coloumb e o modelo do estado crítico Cam-Clay Modificado. Para tanto, realiza-se modelagem numérica bidimensional, com escavação simulada por progressiva redução da rigidez do núcleo, aplicada também ao caso do Túnel Paraíso. Destaque para a definição da rigidez dos materiais no modelo elasto perfeitamente plástico, com base na adoção do módulo tangente inicial $\left(E_{0}\right)$, ao invés do usualmente 
empregado módulo secante correspondente a $50 \%$ da tensão desviadora na ruptura $\left(E_{50}\right)$, opção que se revelou não muito acertada, uma vez que os deslocamentos verticais obtidos se mostraram bem menores que os registrados pela instrumentação de campo, indicando rigidez elevada do meio contínuo. Com relação à análise adotando o modelo Cam-Clay Modificado, vale ressaltar a obtenção dos parâmetros $\lambda$ e $\kappa$ (respectivamente inclinação da linha de compressão isotrópica e inclinação da linha de descompressão, abordados com mais detalhes no Capítulo 4), não baseada nos ensaios edométricos disponíveis (realizados por Parreira, 1991), mas sim no emprego de relações empíricas que vinculam tais parâmetros com o índice de vazios inicial $\left(e_{0}\right)$ de cada material. Ainda assim, os deslocamentos obtidos possuem boa concordância com os dados de instrumentação de campo (sendo melhores que os conseguidos pela análise com o elasto perfeitamente plástico), a menos dos horizontais em profundidade, que se mostram bem maiores que os fornecidos pelo inclinômetro de controle (Figura 2).

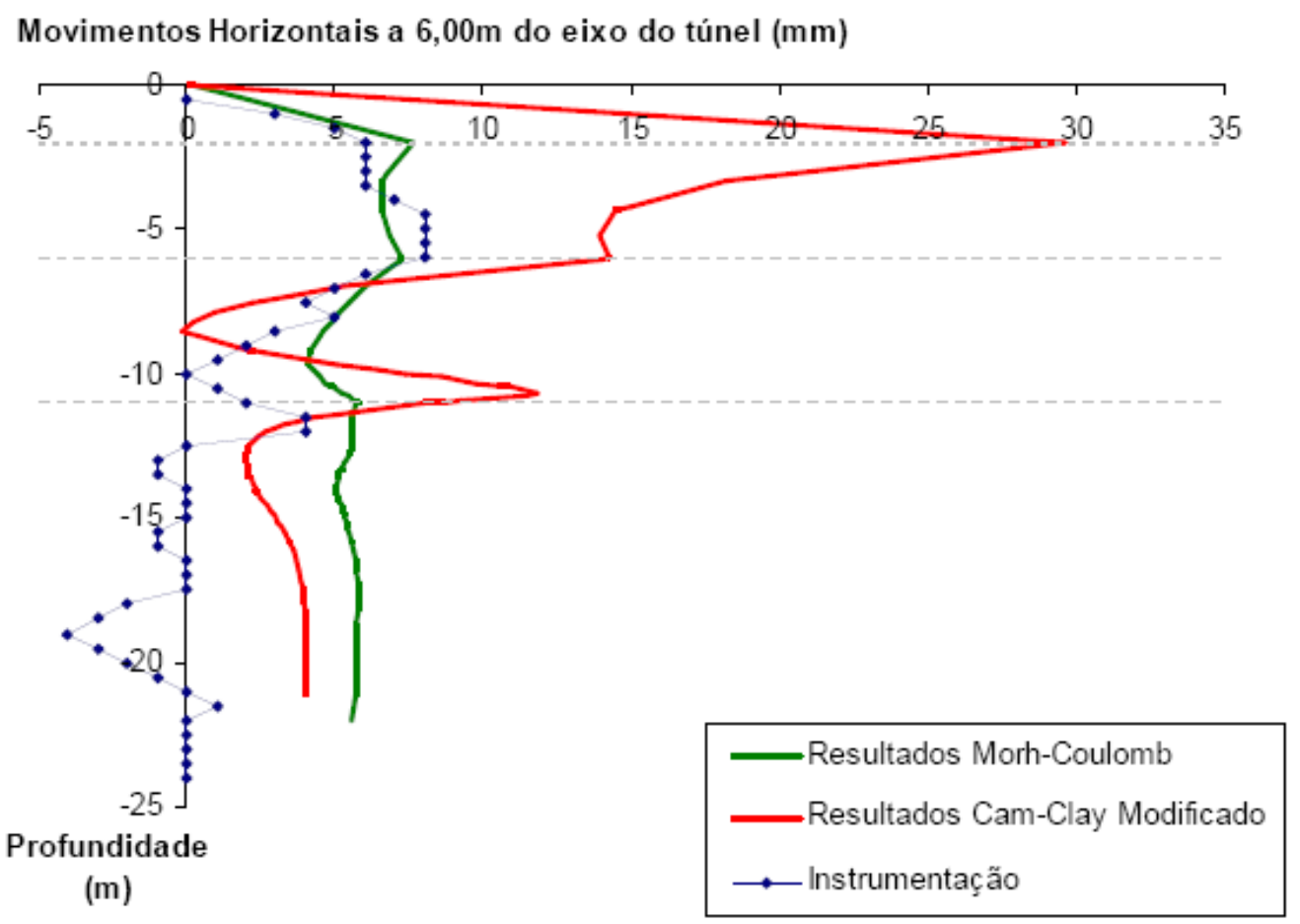

Figura 2 Deslocamentos horizontais em profundidade obtidos com o modelo elasto perfeitamente plástico e com o Cam-Clay Modificado (SILVA, 2008). 
Para encerrar a série de trabalhos que abordam o Túnel Paraíso, apresenta-se o estudo numérico de Sousa et al (2011), envolvendo modelagem bi e tridimensional, com adoção do modelo constitutivo de Lade e do elasto perfeitamente plástico com critério de ruptura de Mohr-Coloumb, focado na investigação dos peculiares deslocamentos verticais em profundidade na região da cobertura do túnel fornecidos pela instrumentação. O conjunto de análises realizadas revela que somente uma acurada simulação do processo de escavação através de uma análise 3D, associada à utilização de um modelo constitutivo que leva em consideração a dependência (variação) da rigidez do solo conforme a trajetória de tensões atuante, como o modelo de Lade, é capaz de reproduzir o peculiar comportamento acima descrito. Fica claro que análises $2 \mathrm{D}$, independentemente do modelo constitutivo adotado, são incapazes de representar de maneira adequada os deslocamentos verticais observados na cobertura do Túnel Paraíso, pelos simples fato de não contemplarem o ciclo completo de tensões próprio de uma escavação subterrânea . Dá-se destaque ainda a outras relevantes particularidades do modelo de Lade que o tornam tão competente na reprodução do comportamento das argilas porosas, tais como o comportamento não linear e a grande compressibilidade permitida.

Franzius \& Potts (2005) apresentam um importante estudo dedicado a investigar as consequiências da prática freqüente de se manterem as dimensões dos modelos numéricos 3D as menores possíveis, para economia de recursos computacionais e de tempo de processamento. A partir do desenvolvimento de inúmeras análises tridimensionais segundo o método passo-a-passo, aplicadas a um túnel circular profundo (cobertura igual a quatro vezes o diâmetro) escavado na Argila de Londres (London Clay), em que são realizadas variações da geometria da malha na direção longitudinal (as características geométricas transversais são mantidas sempre as mesmas), avalia-se a influência da distância às fronteiras verticais da malha (do início e do fundo) nos recalques superficiais induzidos pelo tunelamento. As características geométricas longitudinais variadas foram o comprimento total da malha nesta direção e o comprimento escavado de túnel, sendo que os resultados obtidos indicam que a estabilização dos recalques superficiais a certa distância atrás da frente, característica de uma adequada simulação numérica de escavação subterrânea, pode não ocorrer se houver limitação do comprimento escavado de túnel ou do comprimento de solo existente entre a frente do último passo de avanço e a fronteira de fundo da malha. Vale destacar que não são indicados comprimentos mínimos (proporcionais ao diâmetro da escavação, por exemplo) que de uma maneira geral permitam estabilização dos recalques superficiais, uma vez que o próprio 
trabalho constata que estas medidas mínimas dependem do passo de avanço adotado e das características de cada maciço. Com relação aos maciços, verifica-se que aqueles com baixo coeficiente de empuxo em repouso $\left(K_{0}\right)$ conseguem estabilização dos recalques superficiais a certa distância atrás da frente com menores comprimentos escavados de túnel.

Marques (2006) realiza um amplo trabalho envolvendo ensaios laboratoriais e in situ e modelagem numérica de escavações, voltado a analisar o comportamento de túneis superficiais do Metrô de Brasília, escavados em argilas porosas sobreadensadas e não saturadas (semelhantes às argilas porosas da região do Túnel Paraíso), com processo construtivo baseado no NATM (New Austrian Tunneling Method). São desenvolvidas análises tridimensionais da escavação (método passo-a-passo), adotando o modelo elasto-plástico de Lade, que procuram avaliar o efeito da variação do nível de sucção no comportamento do maciço, empregando diferentes grupos de parâmetros, cada um deles associado a um determinado valor de sucção. Os recalques superficiais conseguidos com estas análises, próximos uns dos outros (sendo os mais concordantes com os dados de instrumentação aqueles associados ao menor valor de sucção), sugerem uma pequena influência da variação de sucção considerada (20 a 100kPa) no comportamento do maciço. Outras análises tridimensionais realizadas dedicaram-se a investigar o impacto da não consideração do sobreadensamento da argila porosa. Verificou-se que o fato de desprezar o sobreadensamento do material (adotando razão de sobreadensamento, $O C R$, igual a um) exerce grande influência no comportamento do maciço, conduzindo a recalques superficiais bem superiores aos fornecidos pela instrumentação. A adoção de um $O C R$ pertinente, superior a unidade, resultou em recalques superficiais que acompanham muito bem os dados de instrumentação de campo.

Grammatikopoulou et al (2008) apresentam um importante estudo dedicado a investigar a influência da história de tensões do solo nos recalques superficiais induzidos pela escavação de um túnel. São realizadas análises bidimensionais (com escavação simulada através de redução gradual da tensão in situ no contorno do túnel) voltadas ao caso de um túnel circular profundo escavado na Argila de Londres (London Clay), depósito com história geológica bem conhecida, nas quais se adota o modelo elasto-plástico Cinemático com Três Superfícies Modificado do Imperial College (GRAMMATIKOPOULOU, 2004), cujo arranjo das superfícies cinemáticas é capaz de prover alguma memória das tensões pré-atuantes. $\mathrm{Na}$ primeira análise com este modelo constitutivo, a escavação é simulada diretamente do estado de tensão geostático, enquanto que na segunda análise, a simulação da escavação é precedida 
pela reprodução da história geológica do maciço, envolvendo deposição, erosão e redeposição. Para a mesma perda de volume de solo, uma bacia de recalques superficiais mais profunda e mais concordante com os dados de instrumentação foi obtida pela análise considerando tensões pré-atuantes devidas aos fenômenos geológicos, o que confirma a influência deste fator no comportamento do maciço e reforça a idéia de considerá-lo, se bem conhecida a história geológica do solo, nas análises por elementos finitos voltadas à previsão de deslocamentos induzidos por escavações de túneis.

Cecílio Jr. (2009) realiza uma interessante pesquisa envolvendo ensaios triaxiais e modelagem numérica tridimensional no Plaxis 3D Tunnel (método passo-a-passo), voltada a um túnel profundo (cobertura igual a três vezes o diâmetro) pertencente à Linha 4 do Metrô de São Paulo, com escavação baseada no NATM, em solo residual de gnaisse. A partir de uma análise tridimensional preliminar do túnel com o modelo elástico linear, em que ao longo do avanço da escavação houve controle das tensões em determinados pontos de uma seção do modelo numérico, foram identificadas as principais trajetórias de tensões atuantes no maciço anteriormente à passagem da frente por esta seção, durante a passagem da frente e com o afastamento da frente, o que permitiu mapear a malha 3D segundo zonas com predominância de determinada trajetória de tensão conforme evolui a escavação (Figura 3). Foram executados, em seguida, ensaios triaxiais seguindo as trajetórias de tensões obtidas numericamente, a fim de obtenção de parâmetros elásticos representativos de cada trajetória. Tais parâmetros alimentaram análises tridimensionais posteriores, adotando o modelo elástico linear, o elasto perfeitamente plástico com critério de ruptura de Mohr-Coloumb e o Hardening do Soil do Plaxis (capaz de considerar rigidezes distintas para situações de carregamento e descarregamento), em que o maciço foi considerado mecanicamente heterogêneo, isto é, as zonas anteriormente definidas no modelo numérico 3D receberam diferentes propriedades elásticas de acordo com a trajetória de tensões predominante. Mesmo não havendo dados de instrumentação de campo para verificação efetiva do desempenho destas análises com o maciço mecanicamente heterogêneo, foi possível observar que seus resultados, comparados aos de análises 3D empregando maciço mecanicamente homogêneo (com parâmetros elásticos vindos exclusivamente de ensaios triaxiais de compressão por carregamento) e os mesmos modelos constitutivos, apresentaram menos disparidade entre si (isto é, as previsões do modelo elástico linear e do elasto perfeitamente plástico ficaram mais próximas das obtidas com o Hardening Soil do Plaxis nas análises adotando o maciço mecanicamente heterogêneo), o que indica que esta metodologia, apesar de laboriosa, 
realmente dá a análises numéricas com modelos constitutivos simples, como o elástico linear e elasto perfeitamente plástico, a possibilidade de considerarem rigidezes elásticas distintas conforme a solicitação sofrida.

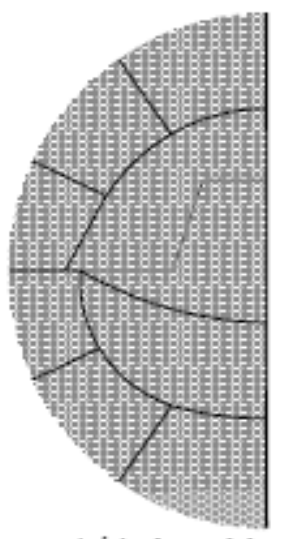

início do modelo $\left(\right.$ de $\left.t_{0}, a t_{1}\right)$

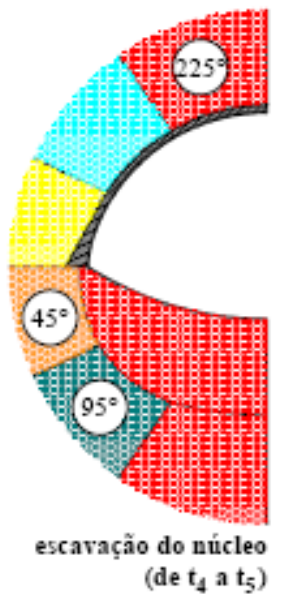

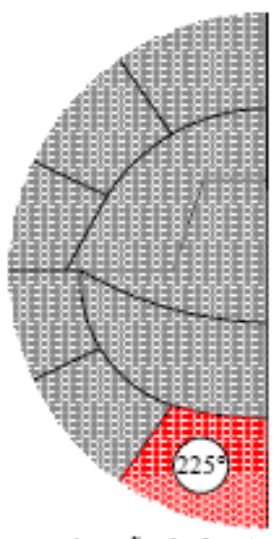

aproximação da frente (de $\left.t_{1} a t_{2}\right)$

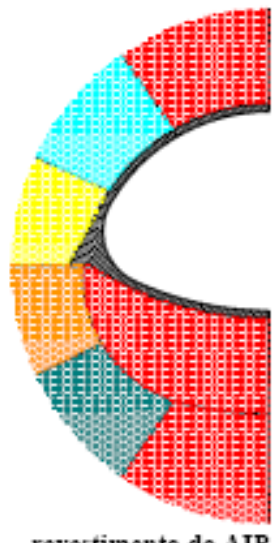
(de $t_{5}, t_{6}$ )

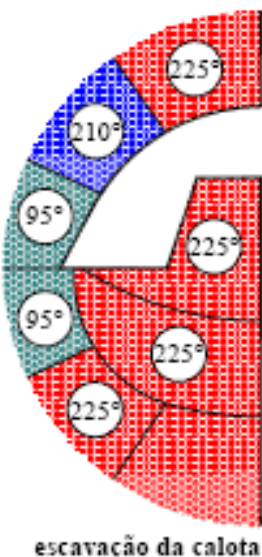

(de $t_{2} a t_{3}$ )

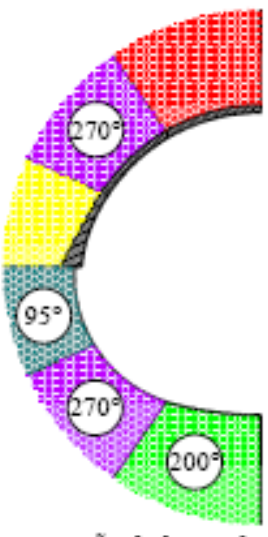

escavação da bancada (de $t_{6} a t_{7}$ )

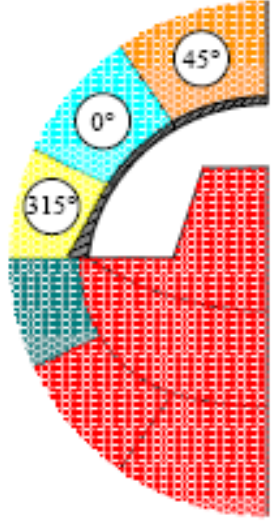

revestimento da calota

(de $t_{3}, t_{4}$ )

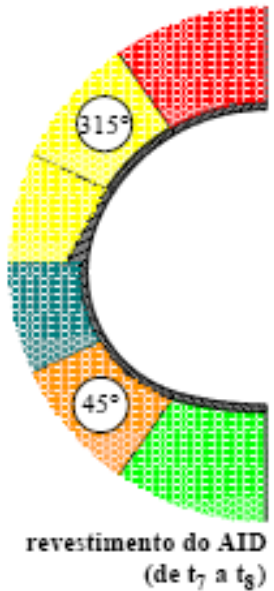

Figura 3 Mapeamento segundo zonas com predominância de determinada trajetória de tensão conforme evolui a escavação (CECÍLIO JR., 2009). 


\section{ESTUDO DE CASO - O TÚNEL PARAÍSO}

O Túnel Paraíso, pertencente à Linha 2 - Verde do Metrô de São Paulo, está localizado em uma das áreas mais importantes da cidade, região da Avenida Paulista, referência nacional no setor financeiro, de serviços e cultural. Foi executado no fim da década de oitenta, adotando processo construtivo baseado no NATM (New Austrian Tunneling Method), motivo pelo qual é também conhecido por Túnel Mineiro Paraíso. Com cerca de $103 \mathrm{~m}$ de extensão e $80 \mathrm{~m}^{2}$ de área escavada (largura máxima de 11,5m - geometria completa da seção na Figura 4), passa exatamente sob a Rua do Paraíso, situado entre dois poços construídos previamente através do método de vala a céu aberto, conforme mostra Figura 5. Por apresentar cobertura de apenas 7,6m, inferior a um diâmetro, pode ser incluído na categoria de túneis rasos ou superficiais.

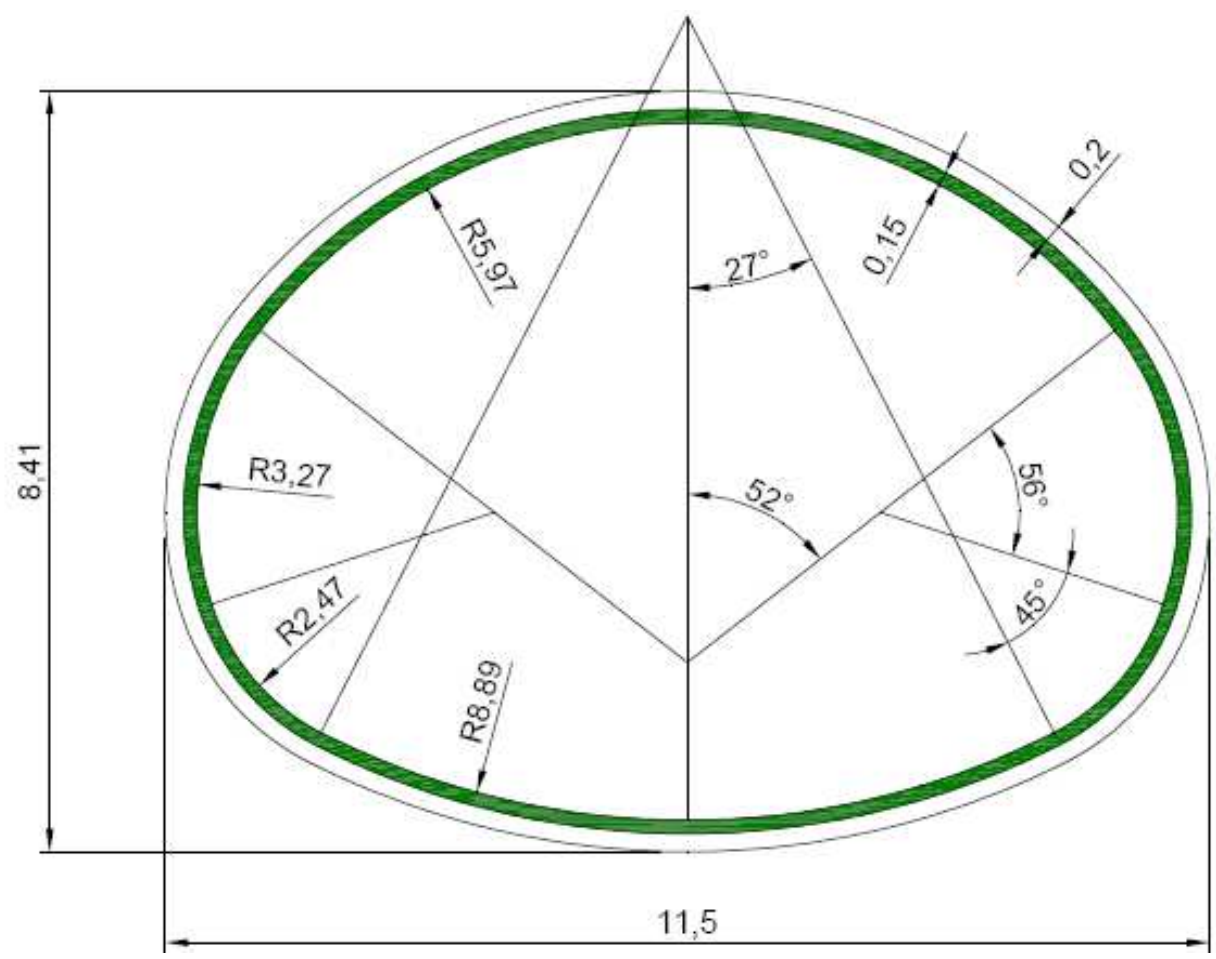

Figura 4 Geometria da seção - medidas em m (SILVA, 2008). 


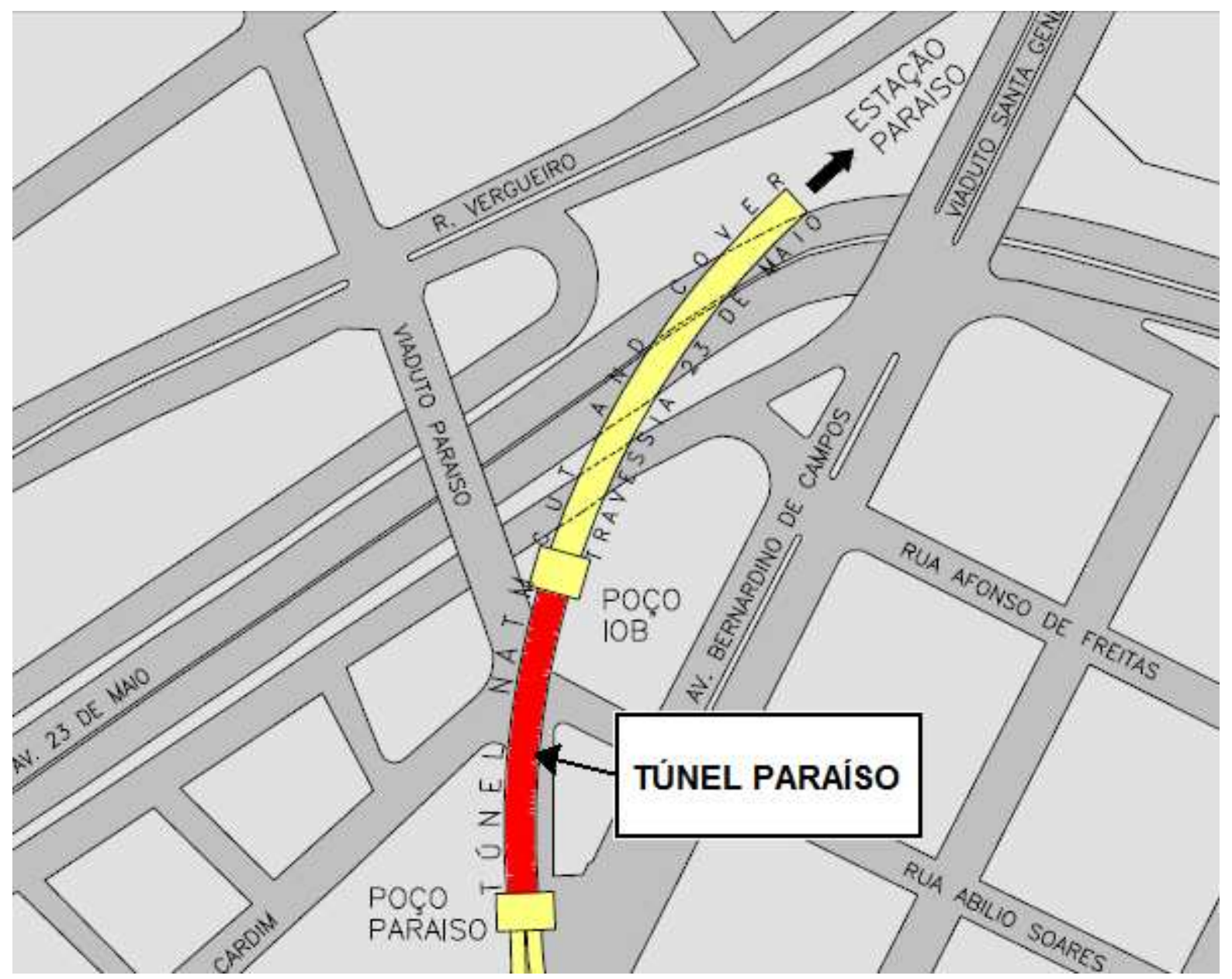

Figura 5 Localização da obra (adaptada de FRANÇA, 2006).

Foi escavado em solos sedimentares argilosos típicos das partes mais altas da Bacia de São Paulo, acima da cota $750 \mathrm{~m}$ em relação ao nível do mar, cuja origem se remontaria ao Terciário, ocorrendo através de sedimentação em águas paradas e profundas. Sob ação de intempéries teriam ainda sofrido erosão, lixiviação e laterização, o que fez com que na parte superior, não ultrapassando os $25 \mathrm{~m}$ de profundidade, houvesse predomínio de uma argila homogênea, de cor vermelha, não saturada, muito porosa, cuja consistência varia de mole a dura e, logo abaixo, a presença de solos argilosos variegados. Em virtude do processo de laterização a que estas argilas estiveram submetidas, as pressões de pré-adensamento devem ter sido de alguma forma alteradas, não se relacionando com a cota ou profundidade, variando entre 50 e $700 \mathrm{kN} / \mathrm{m}^{2}$, o que faz com que a razão de sobreadensamento destes estratos superficiais seja em geral superior a unidade (MASSAD, 1974). 


\subsection{PERFIL GEOTÉCNICO}

O perfil geotécnico do local, definido a partir de inúmeros furos de sondagem, aparece na Figura 6 e se encontra resumido a seguir:

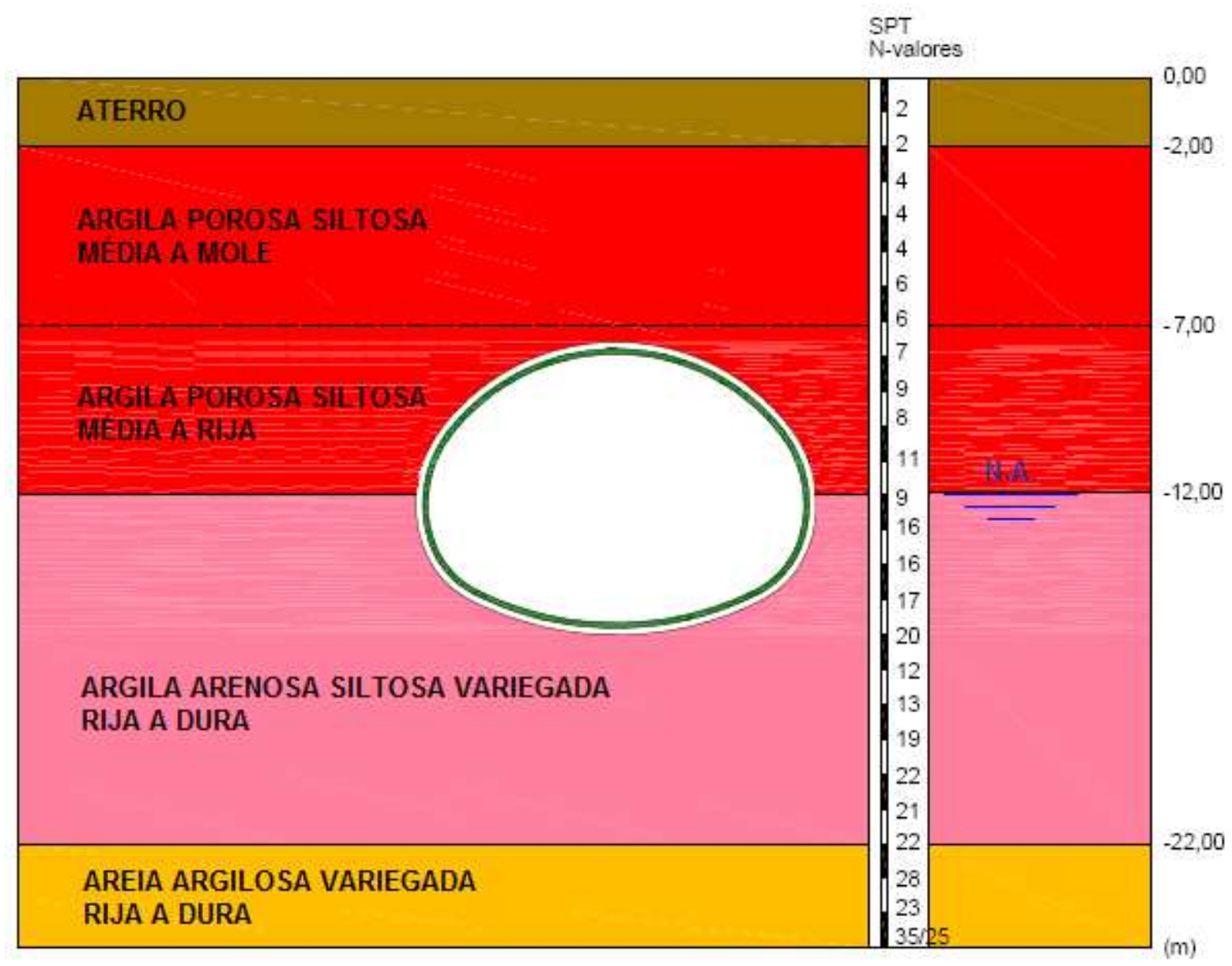

Figura 6 Perfil geotécnico do local (adaptada de SILVA, 2008).

- de 0 a $2 \mathrm{~m}$ : camada superficial de aterro;

- de 2 a 7m: camada de argila porosa siltosa vermelha, não saturada, de consistência média a mole $\left(4 \leq \mathrm{N}_{\mathrm{SPT}} \leq 6\right)$;

- de 7 a 12m: camada de argila porosa siltosa vermelha, não saturada, de consistência média a rija $\left(7 \leq \mathrm{N}_{\mathrm{SPT}} \leq 11\right)$; 
- de 12 a 22m: camada de argila arenosa siltosa variegada, saturada, de consistência rija a dura $\left(12 \leq \mathrm{N}_{\mathrm{SPT}} \leq 22\right)$;

- a partir de 22m: camada de areia argilosa variegada, saturada, muito compacta $\left(\mathrm{N}_{\mathrm{SPT}} \geq 23\right)$.

O nível d'água foi registrado há $12 \mathrm{~m}$ da superfície do terreno, coincidindo com o início da camada de argila arenosa siltosa variegada.

\subsection{PROCESSO CONSTRUTIVO}

O Túnel Paraíso foi executado adotando processo construtivo baseado no NATM, com parcialização do tipo calota e bancada, e emprego de perfis metálicos e concreto projetado como estrutura de suporte. A escavação se deu através de duas frentes de trabalho que partiram em sentidos opostos de poços previamente estabelecidos nas extremidades do túnel. A frente de trabalho analisada no presente estudo, trecho com $72 \mathrm{~m}$ de extensão a partir do Poço IOB, que contém a seção instrumentada $\mathrm{S} \emptyset 2$ de onde foram extraídos os dados de deslocamentos do maciço (ver Figura 7), apresentou a seguinte seqüência construtiva (a leitura deve ser acompanhada da visualização da Figura 8):

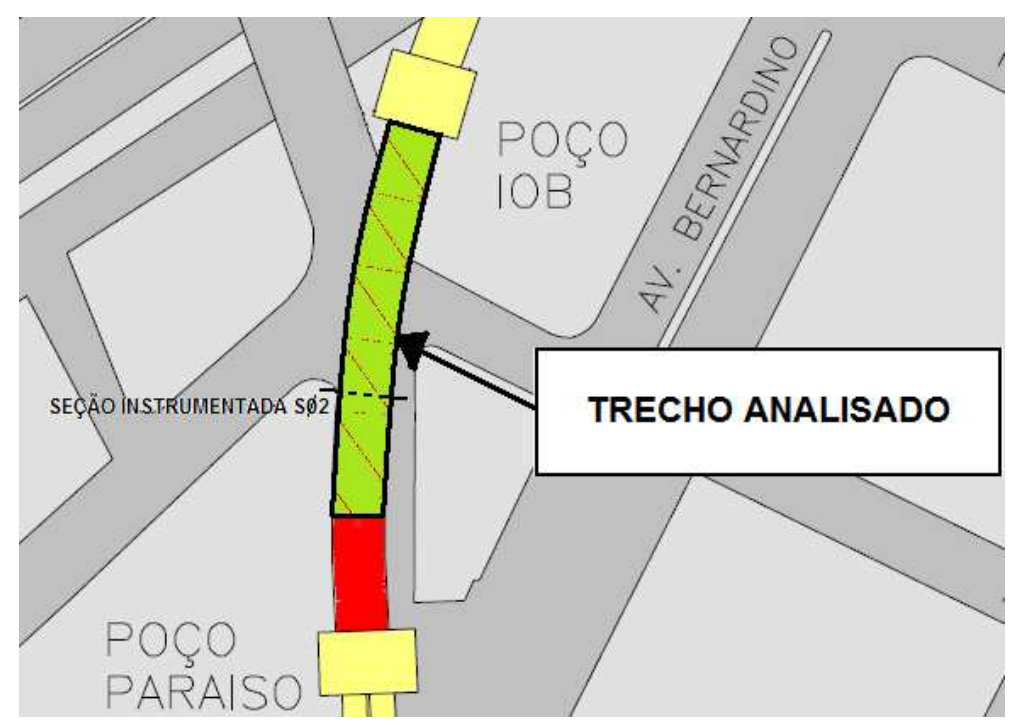

Figura 7 Indicação do trecho analisado (adaptada de FRANÇA, 2006). 


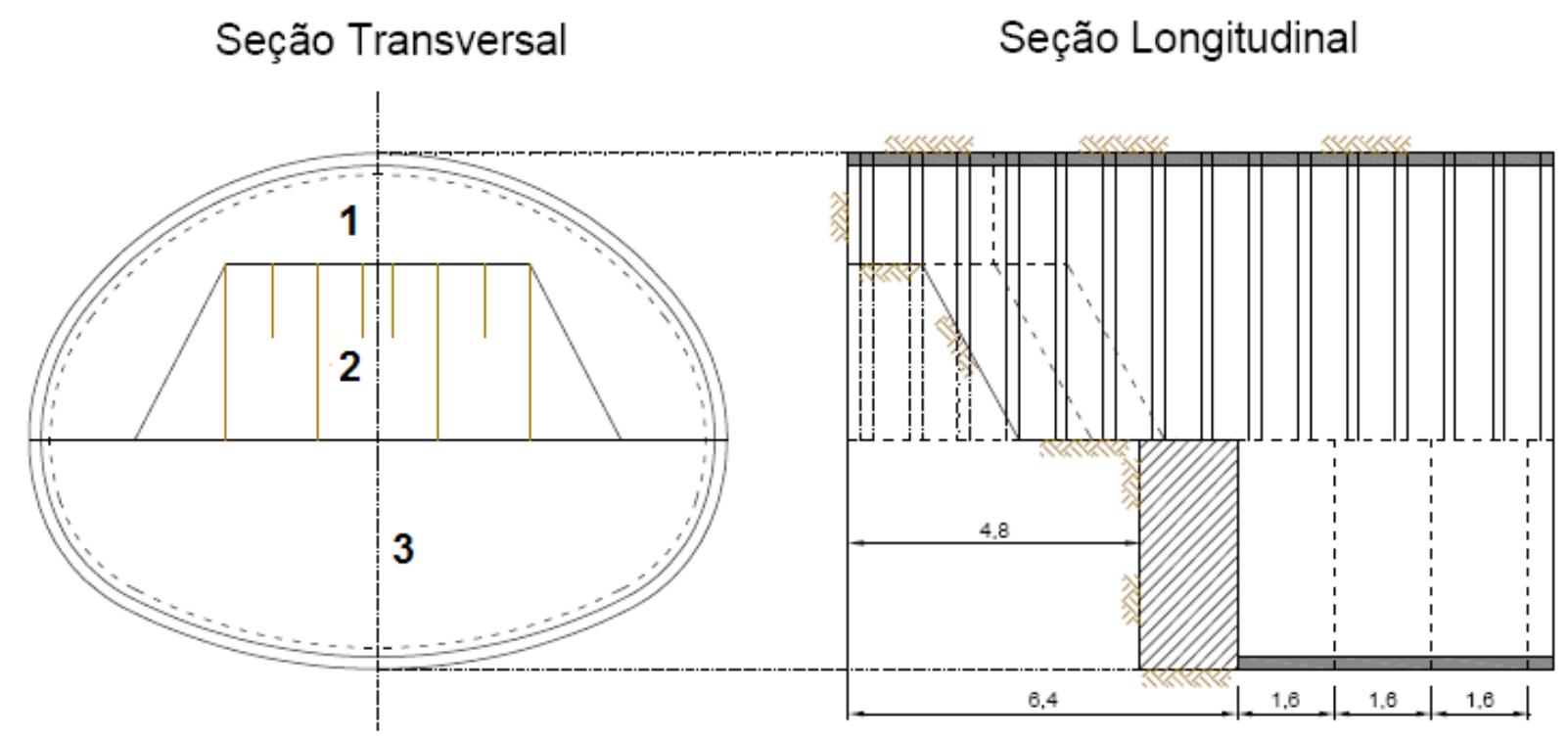

Figura 8 Representação do processo construtivo (adaptada de SILVA, 2008).

- inicialmente, escavava-se a calota, área indicada pelo número 1, com passos de avanço de $1,6 \mathrm{~m}$, sendo que imediatamente após a escavação do passo eram instalados dois perfis metálicos (tipo I, com altura de $12,5 \mathrm{~cm}$, um a cada $0,80 \mathrm{~m}$ ) e aplicado concreto projeto $(20 \mathrm{~cm}$ de espessura);

- em seguida, escavava-se a região indicada pelo número 2 , de maneira que fosse mantida uma porção de solo, núcleo central, cujo talude defasava dois avanços $(3,2 \mathrm{~m})$ em relação à face da calota;

- com defasagem de três avanços $(4,8 \mathrm{~m})$ com relação à face da calota, escavava-se a bancada (ou arco invertido), área indicada pelo número 3, com passos de avanço também de 1,6m, aplicando logo após a escavação concreto projetado sobre tela metálica (CA 50B);

- uma vez definida a defasagem entre regiões 1,2 e 3 apresentada na seção longitudinal da Figura 8, prosseguia-se com avanços simultâneos das mesmas, de maneira a manter esta configuração na longitudinal, a passos de 1,6m, instalando a estrutura de suporte conforme indicação realizada nos itens anteriores. 


\subsection{INSTRUMENTAÇÃO}

Com o intuito de se monitorar o comportamento do maciço frente à escavação, algumas seções ao longo do túnel receberam instrumentos de medida de deslocamentos, tais como placas de recalque superficial, extensômetros magnéticos e inclinômetros. A seção adotada como referência por este estudo, Seção SØ2, localizada a 40m do Poço IOB, de onde partiu a frente de trabalho a ser analisada numericamente, apresentava a distribuição de instrumentos indicada em planta e em corte respectivamente nas Figuras 9 e 10.

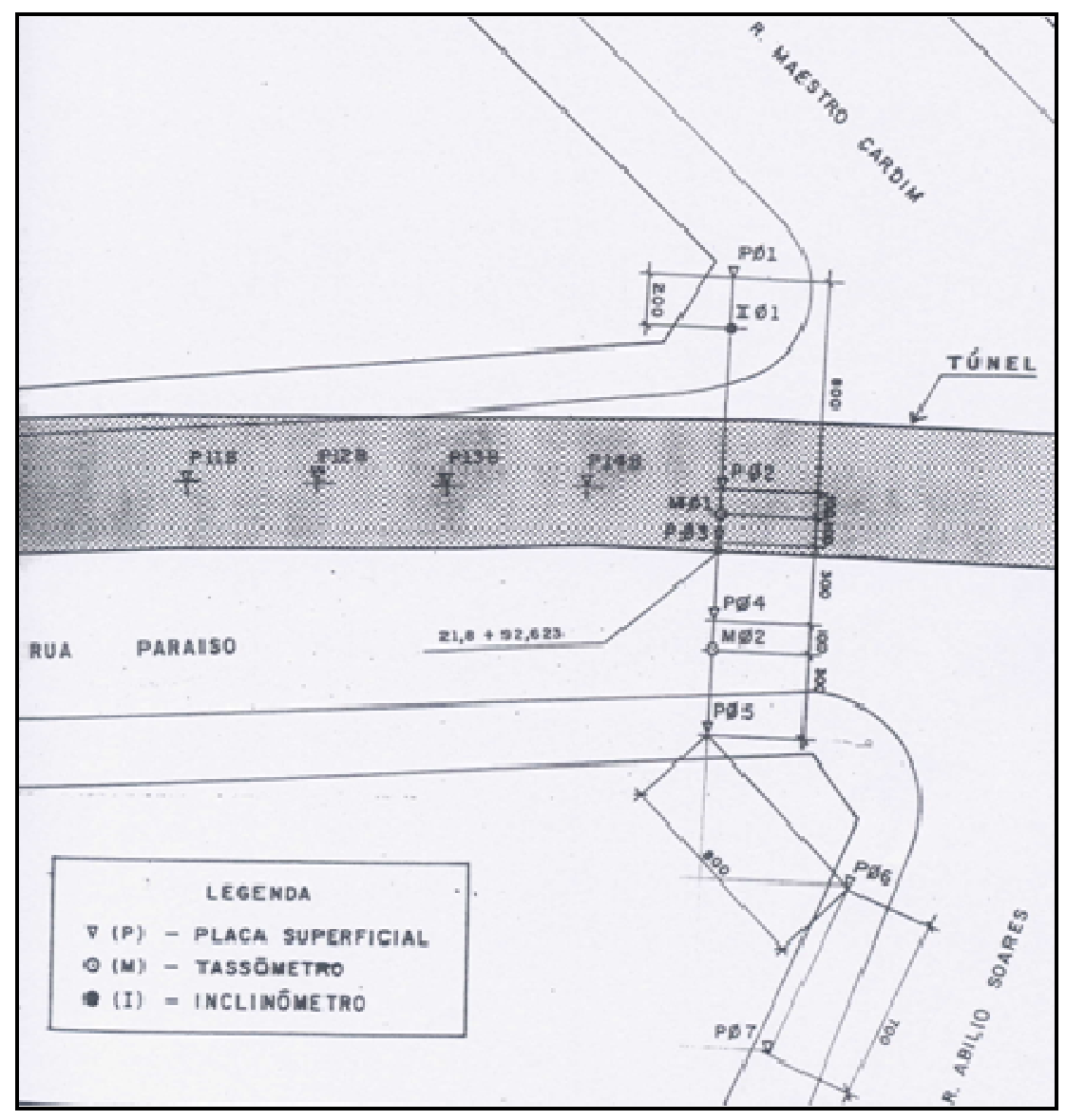

Figura 9 Vista em planta da seção instrumentada SØ2 - medidas em cm (PARREIRA, 1991). 


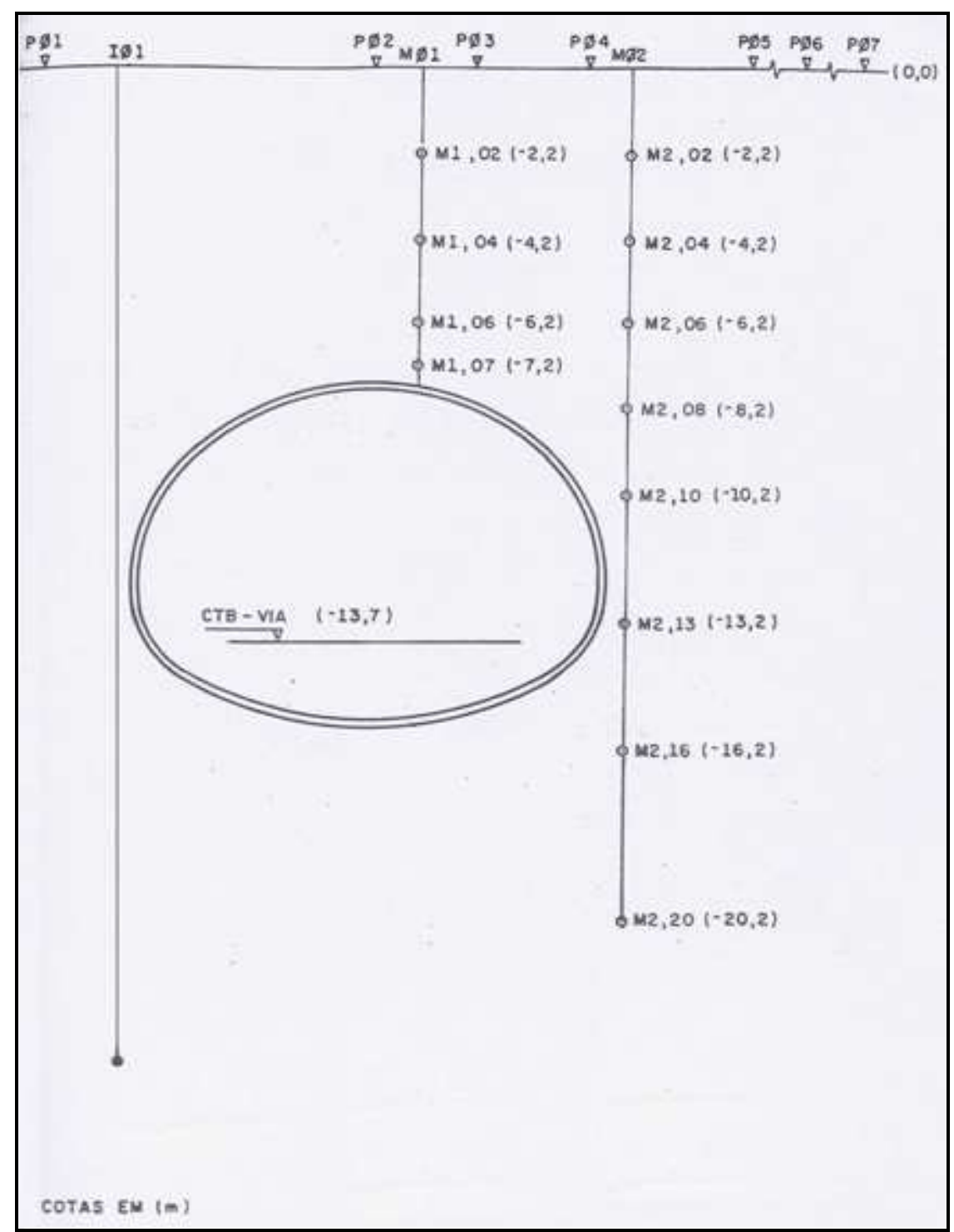

Figura 10 Vista em corte da seção instrumentada SØ2 (adaptada de PARREIRA, 1991).

Ao fim da escavação da frente de trabalho em análise, com $72 \mathrm{~m}$ de extensão, as placas de recalque superficial registravam os deslocamentos verticais apresentados na Figura 11. 
Distância do eixo do túnel (m)

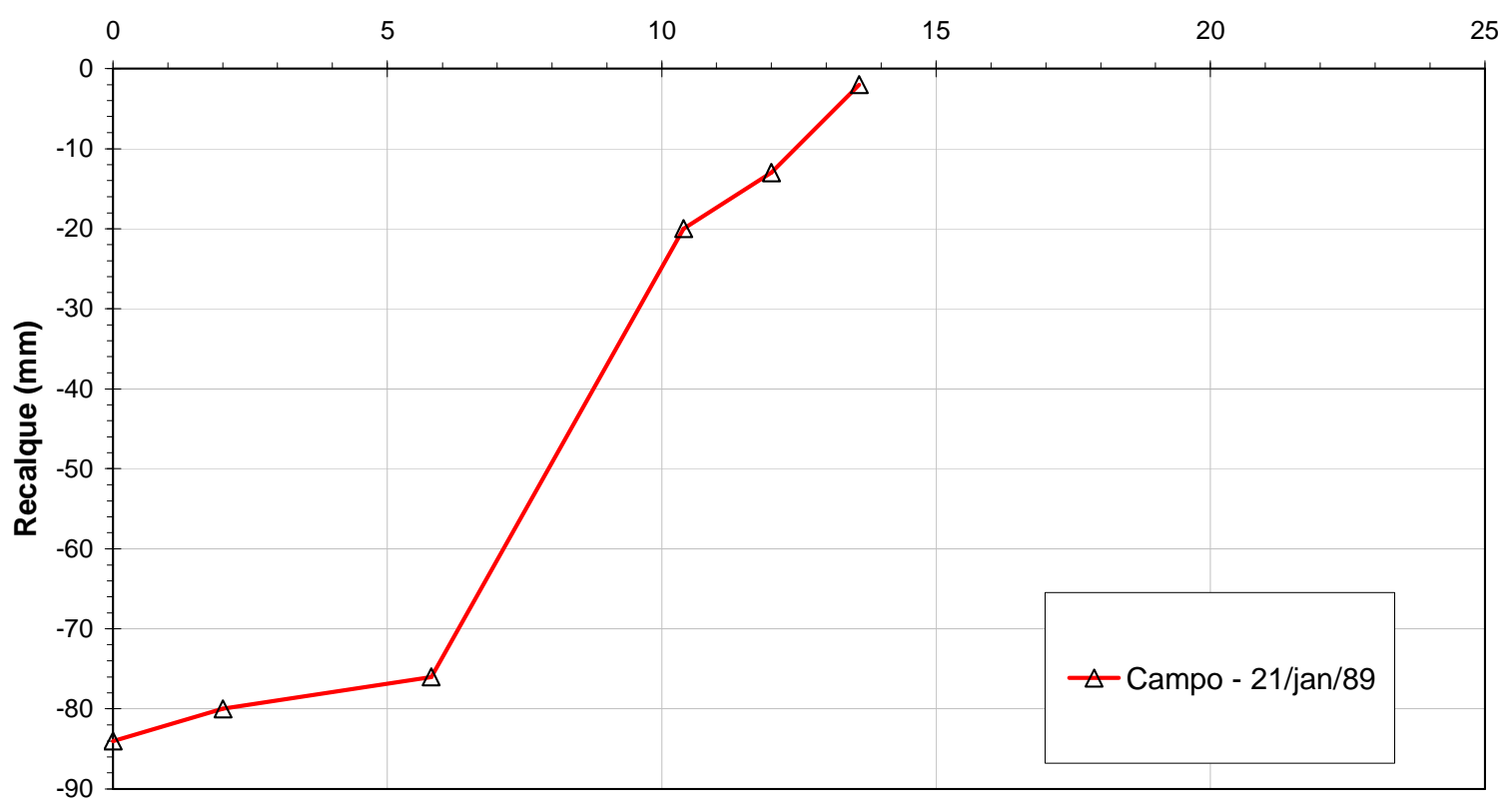

Figura 11 Bacia de recalques superficiais (SOUSA, 1998).

Também ao fim da escavação do trecho analisado, os extensômetros magnéticos posicionados a cerca de $1 \mathrm{~m}$ do eixo do túnel e os situados a $6 \mathrm{~m}$ do eixo indicavam os deslocamentos verticais apresentados respectivamente nas Figuras 12 e 13.

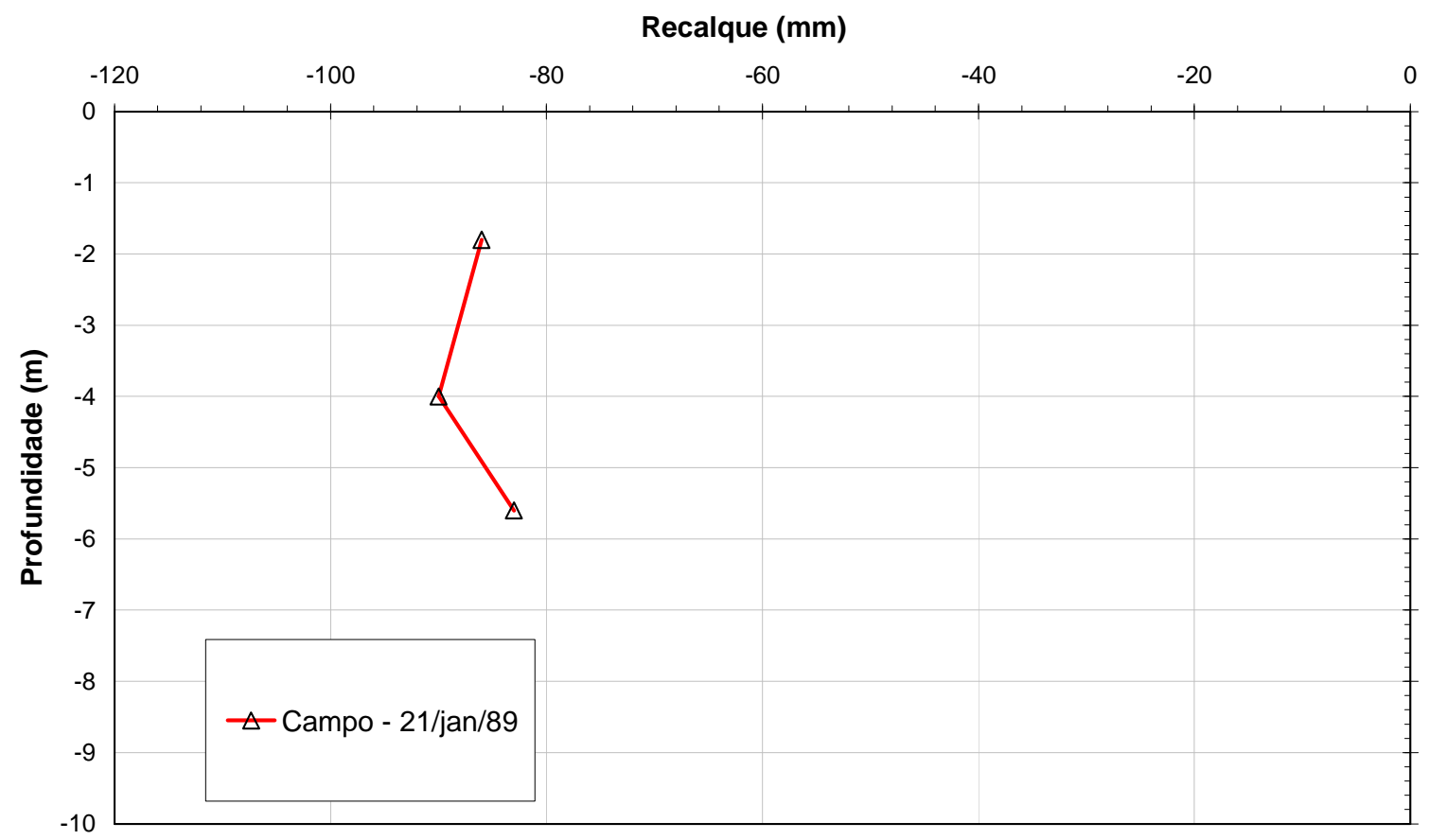

Figura 12 Recalques em profundidade - ext. magnéticos a 1m do eixo do túnel (SOUSA, 1998). 


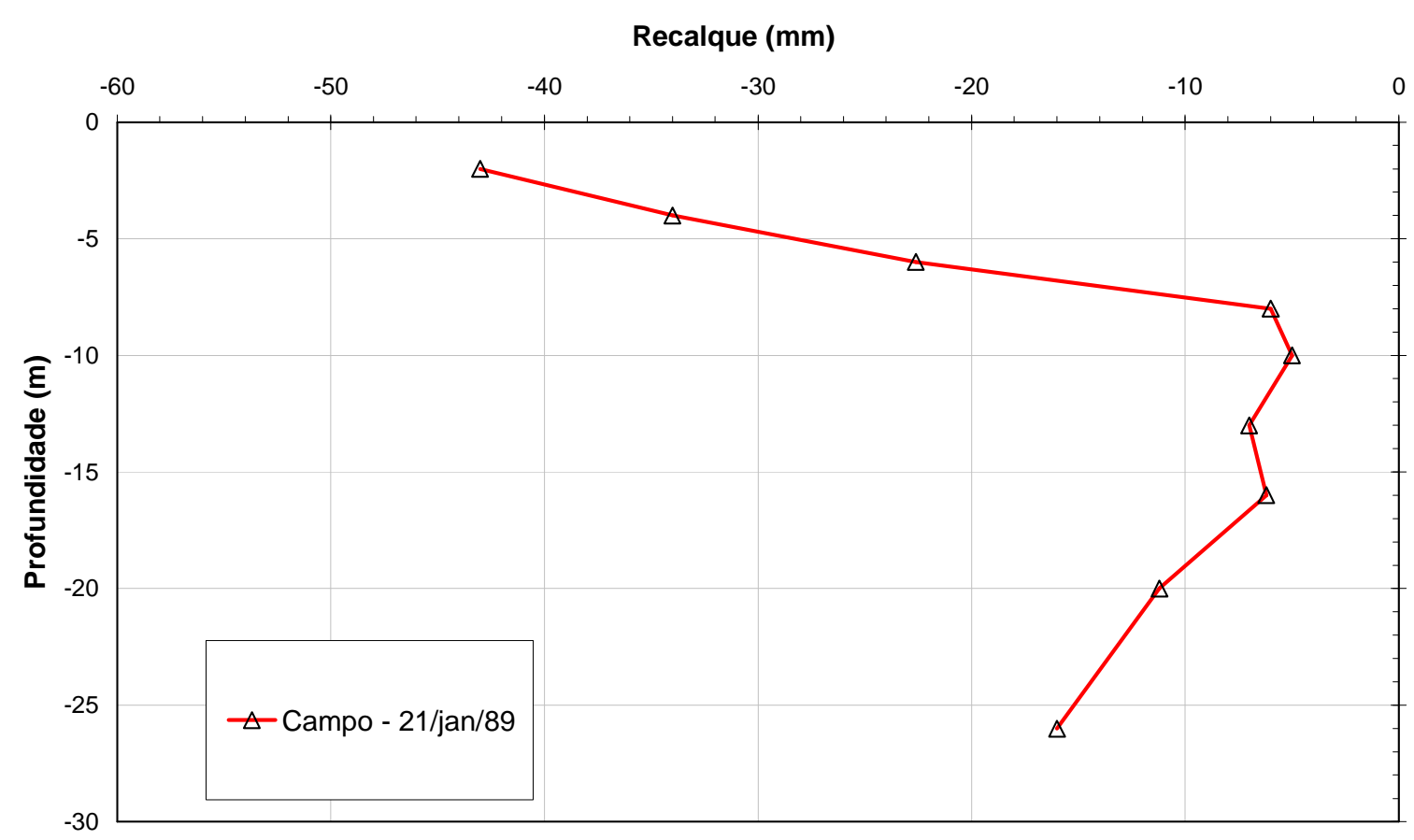

Figura 13 Recalques em profundidade - ext. magnéticos a 6m do eixo do túnel (SOUSA, 1998).

Vale destacar a peculiar característica dos deslocamentos verticais em profundidade na região da cobertura do túnel, evidenciada pelos extensômetros magnéticos posicionados a aproximadamente $1 \mathrm{~m}$ de seu eixo. Tais deslocamentos, geralmente maiores junto à calota do túnel e menores nas proximidades da superfície, como sugere, por exemplo, a expressão proposta por Mair et al (1993), apresentada na Figura 14, são no caso do Túnel Paraíso e de outros túneis escavados em argilas porosas com comportamento fortemente determinado pela estrutura, como os do Metrô de Brasília (abordados no Capítulo 2), de tendência oposta, isto é, maiores nas proximidades da superfície do que junto à calota. Tal característica será discutida com mais detalhes no Capítulo 4. 


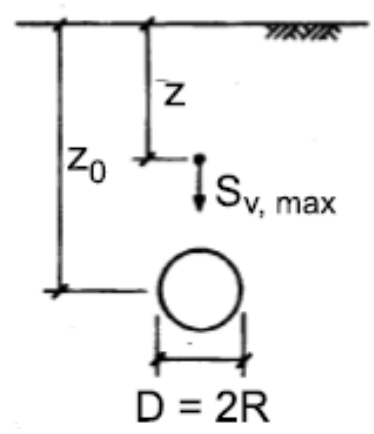

$$
\frac{S_{\mathrm{v}, \max }}{R}=\frac{1.25 V_{\mathrm{L}}}{0.175+0.325\left(1-\frac{z}{z_{0}}\right)} \frac{R}{z_{0}}
$$

Figura 14 Equação propondo deslocamentos verticais $\left(S_{\mathrm{v}}\right)$ crescentes com a profundidade na cobertura do túnel (MAIR et al, 1993). $\mathrm{V}_{\mathrm{L}}$ é a perda de volume por unidade de comprimento.

Na Figura 15, observam-se os deslocamentos horizontais registrados, também ao final da escavação, pelo inclinômetro posicionado a $6 \mathrm{~m}$ do eixo do túnel.

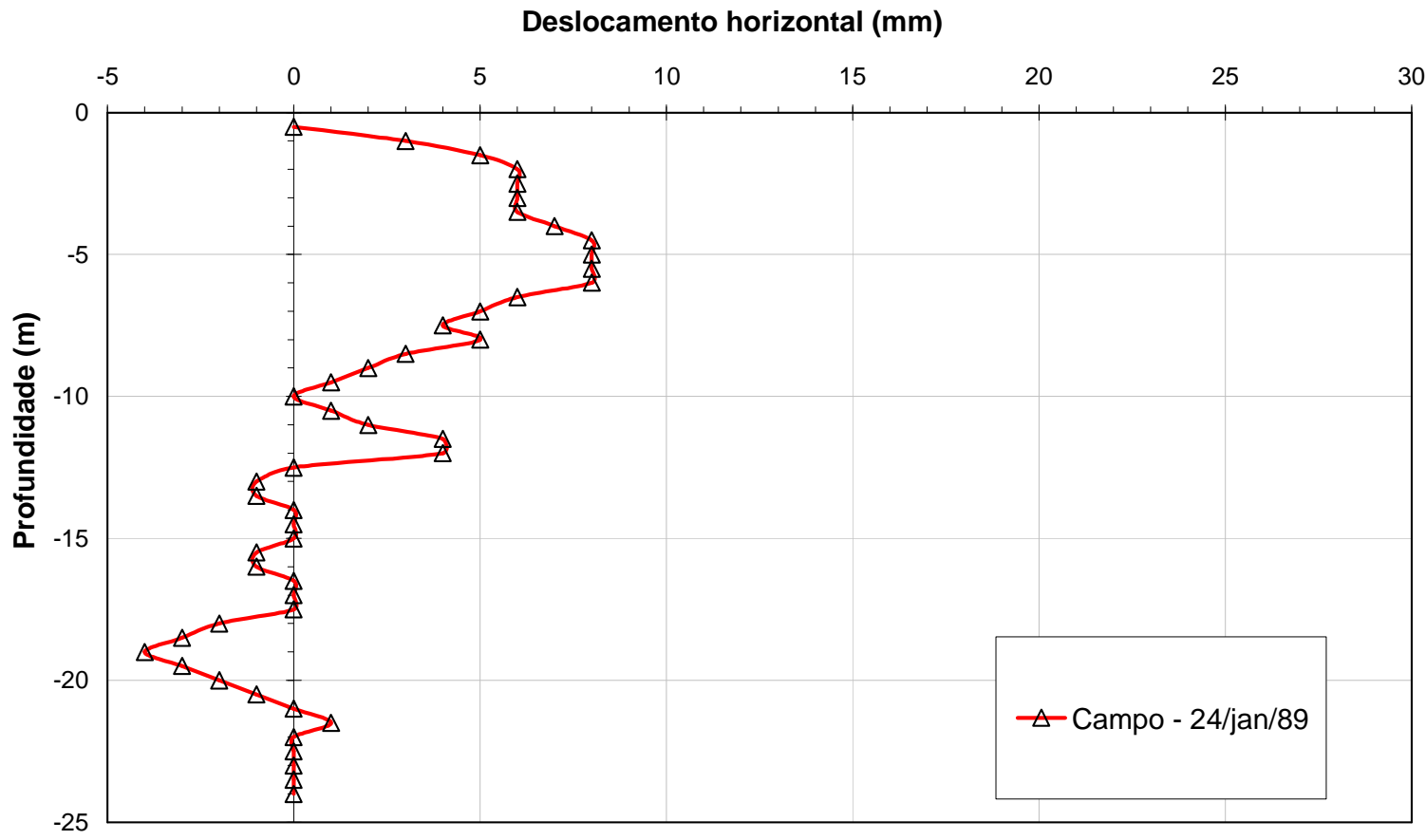

Figura 15 Deslocamentos horizontais - inclinômetro a 6m do eixo do túnel (SOUSA, 1998).

Os deslocamentos verticais registrados com o avanço da escavação pela placa de recalque superficial alinhada com o eixo do túnel (no plano da seção instrumentada) aparecem na Figura 16. 


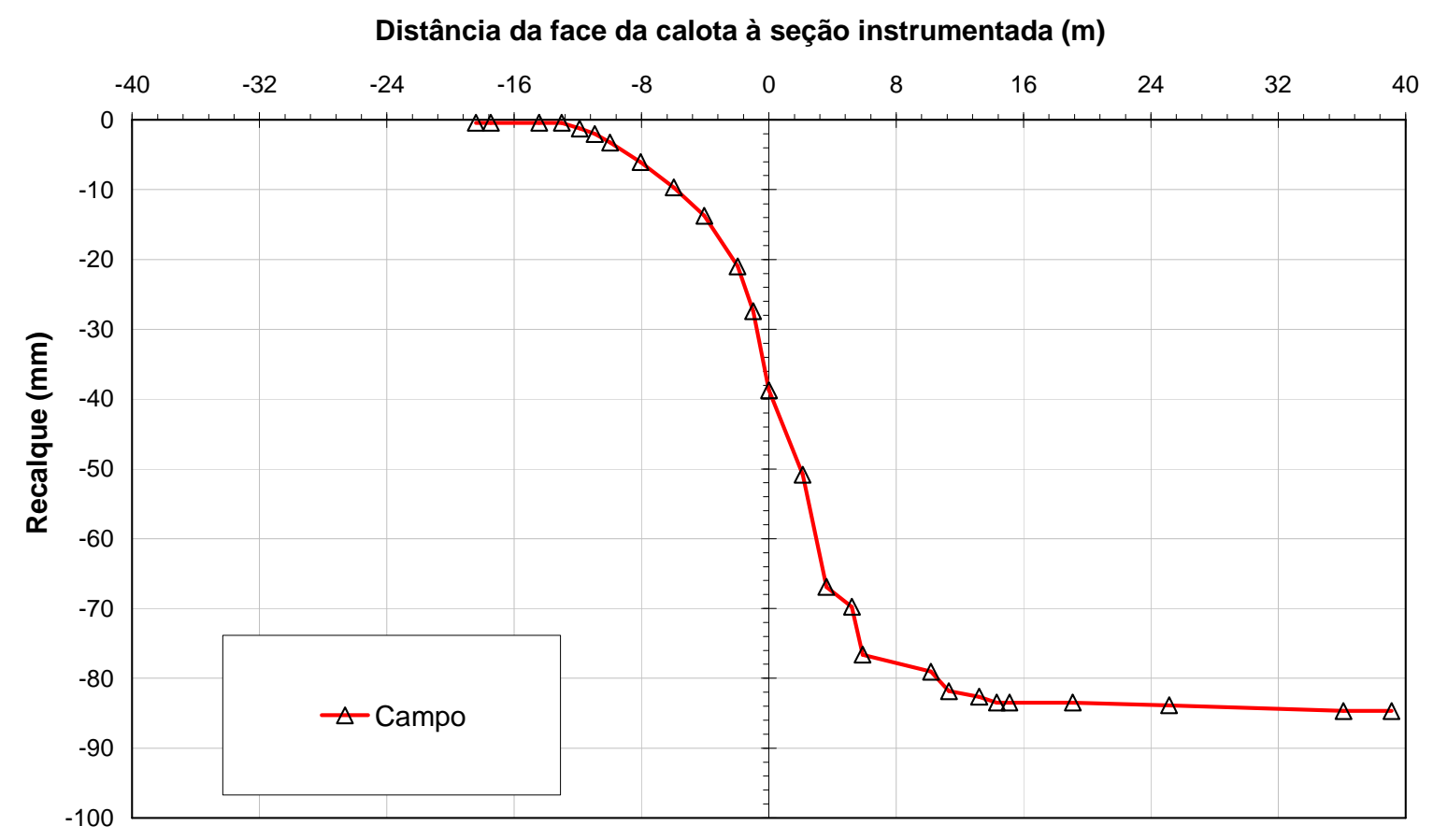

Figura 16 Recalques à superfície conforme avança a escavação - placa de recalque superficial alinhada com o eixo do túnel (SOUSA, 1998).

\subsection{ENSAIOS}

Parreira (1991) realizou uma série de ensaios em blocos de material indeformado extraídos de um poço de $2 \mathrm{~m}$ de diâmetro, escavado junto à Avenida Paulista, nas proximidades do Edifício da TV Gazeta, local cujo subsolo apresenta os mesmos materiais encontrados no maciço onde foi escavado o Túnel Paraíso, conforme indica o perfil geotécnico do poço, exibido na Figura 17. Tal perfil geotécnico mostra ainda que estes blocos, retirados das profundidades $3,5 \mathrm{~m}$, $6,5 \mathrm{~m}$ e $9,5 \mathrm{~m}$, representam, respectivamente, a argila porosa vermelha média a mole, a argila porosa vermelha média a rija e a argila variegada. A fim de obtenção de parâmetros dos solos, o presente estudo selecionou alguns dos ensaios realizados, apresentando seus resultados a seguir. De agora em diante, a argila porosa média a mole (material do bloco de profundidade 3,5m) será referida como Argila Porosa 1 (AP1), assim como a argila porosa média a rija (material do bloco de profundidade 6,5m) será tratada como Argila Porosa 2 (AP2). A Argila Variegada (material do bloco de profundidade 9,5m) continuará sendo assim denominada, tendo sigla AV. 
$S P-312$

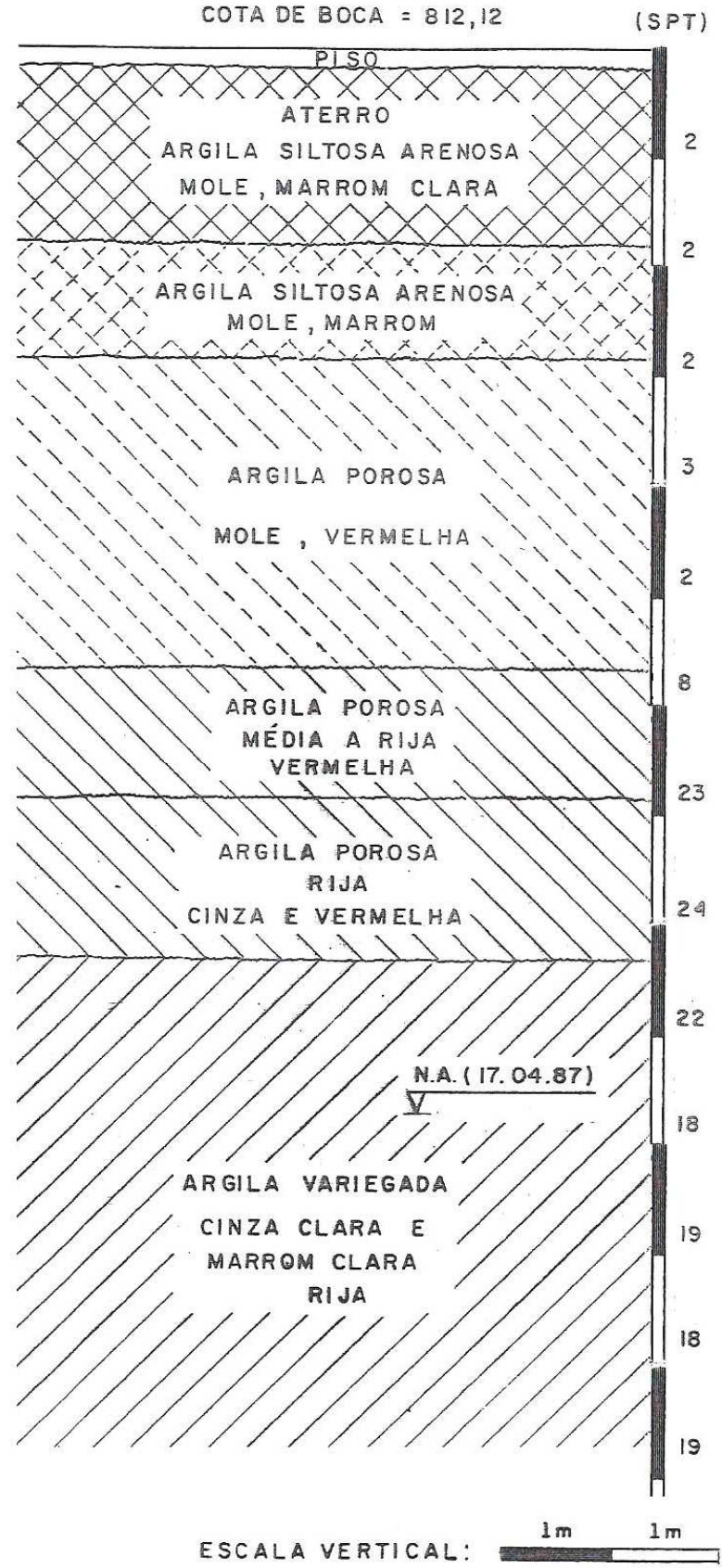

Figura 17 Perfil geotécnico do Poço Experimental Gazeta (PARREIRA, 1991).

Dos ensaios triaxiais drenados de compressão por carregamento disponíveis para cada material (realizados segundo diferentes tensões de confinamento), foi selecionado para calibração aquele cuja tensão efetiva média ( $\left(p^{\prime}\right)$ da fase de confinamento mais se assemelhava à tensão efetiva média da condição inicial do material no campo ( $p$ ' do ponto médio de sua camada no maciço do Túnel Paraíso). As Figuras 18 a 20 apresentam os resultados dos 
ensaios escolhidos, sendo a tensão de confinamento referente a cada um deles indicada no texto de esclarecimento das figuras.
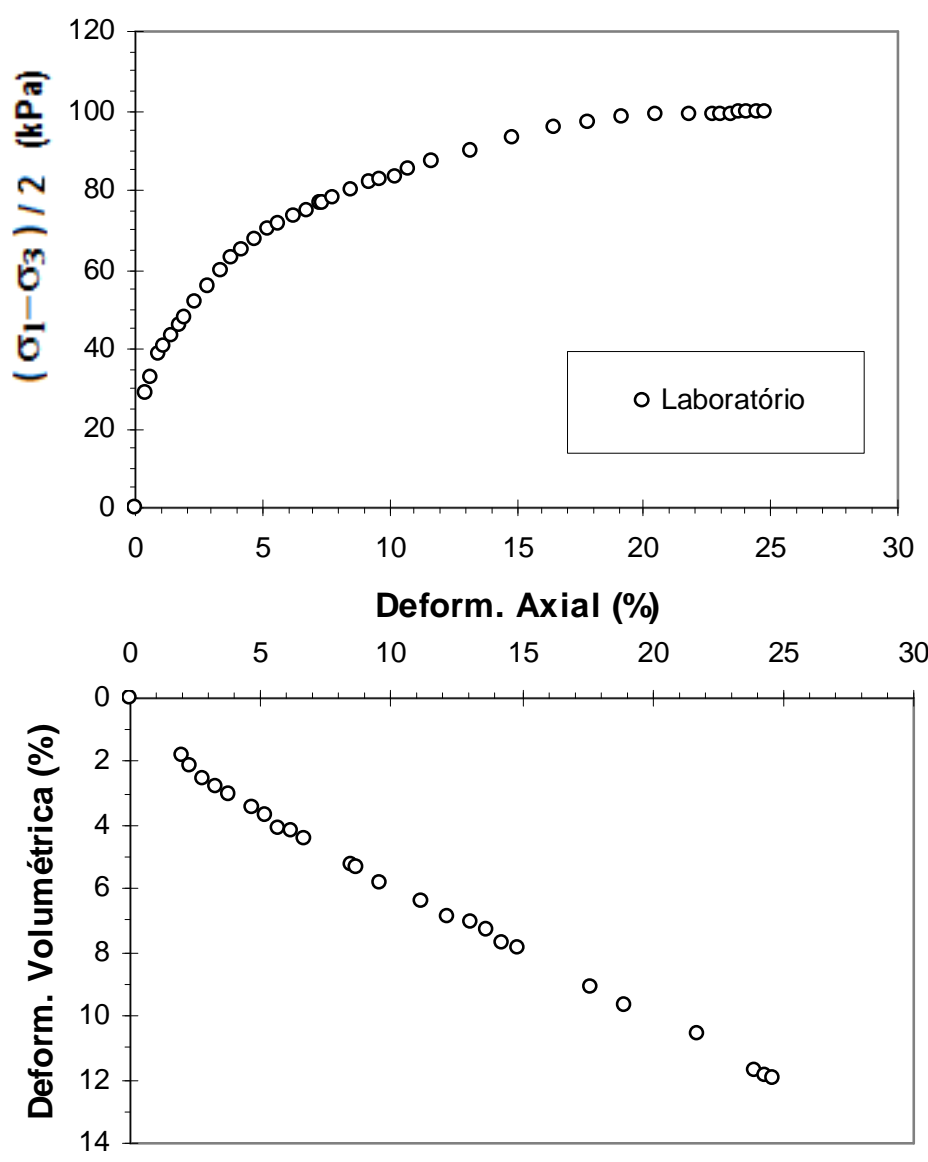

Figura 18 Ensaio triaxial drenado de compressão por carregamento - AP1 $\left(\sigma_{3}=49 \mathrm{kPa}\right)$. 

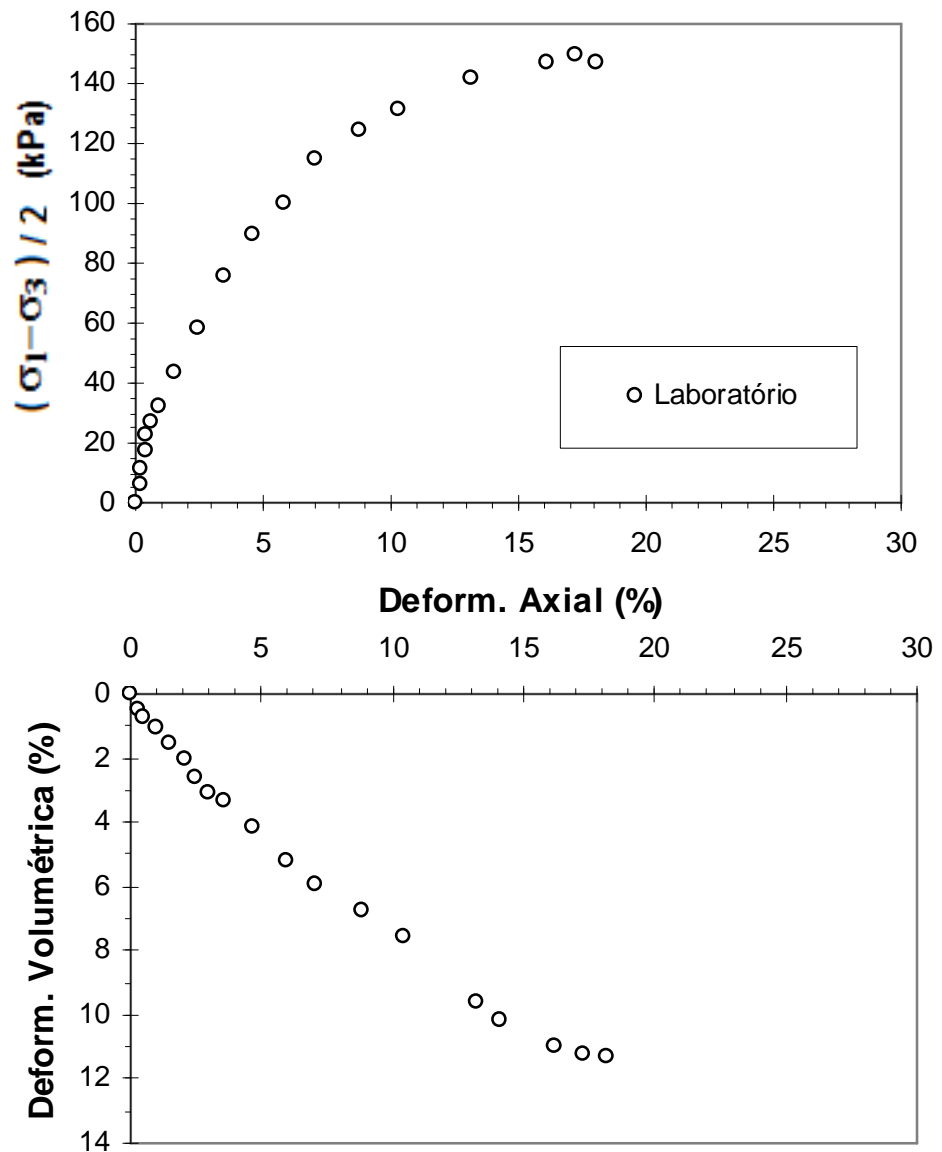

Figura 19 Ensaio triaxial drenado de compressão por carregamento - AP2 $\left(\sigma_{3}=98,1 \mathrm{kPa}\right)$. 

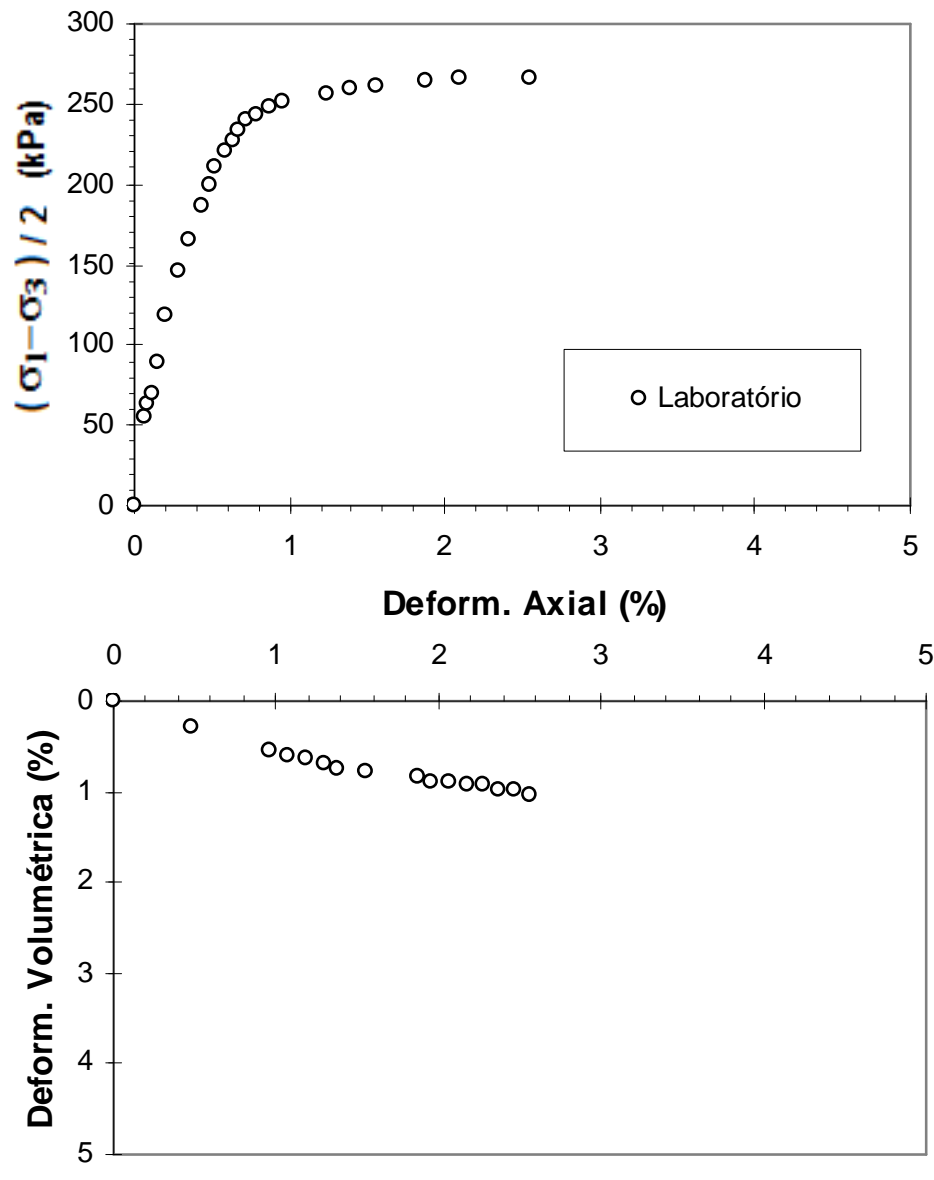

Figura 20 Ensaio triaxial drenado de compressão por carregamento - AV $\left(\sigma_{3}=196,1 \mathrm{kPa}\right)$.

Os resultados dos ensaios edométricos referentes à Argila Porosa 1, Argila Porosa 2 e Argila Variegada aparecem respectivamente nas Figuras 21, 22 e 23.

Tensão Vertical (kPa)

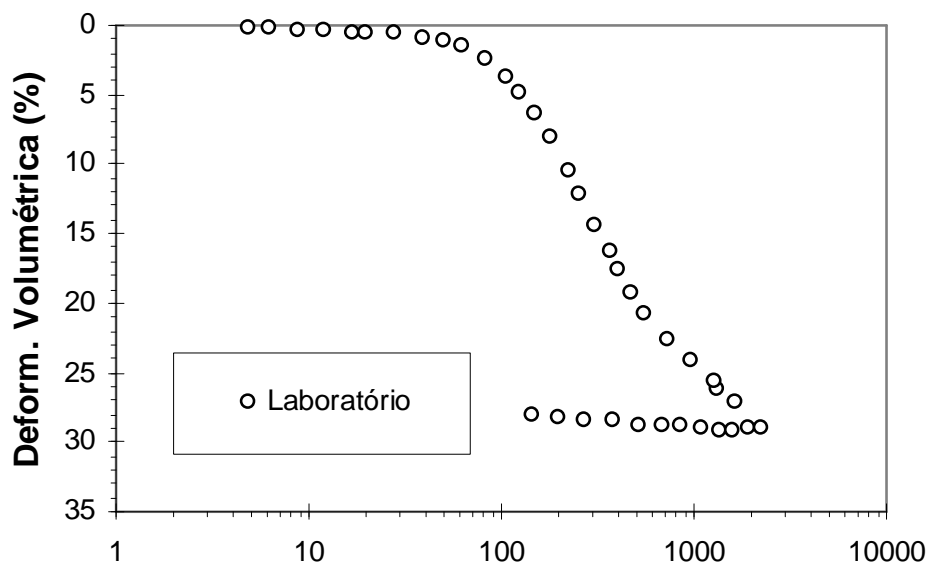

Figura $21 \quad$ Ensaio edométrico - AP1. 
Tensão Vertical (kPa)

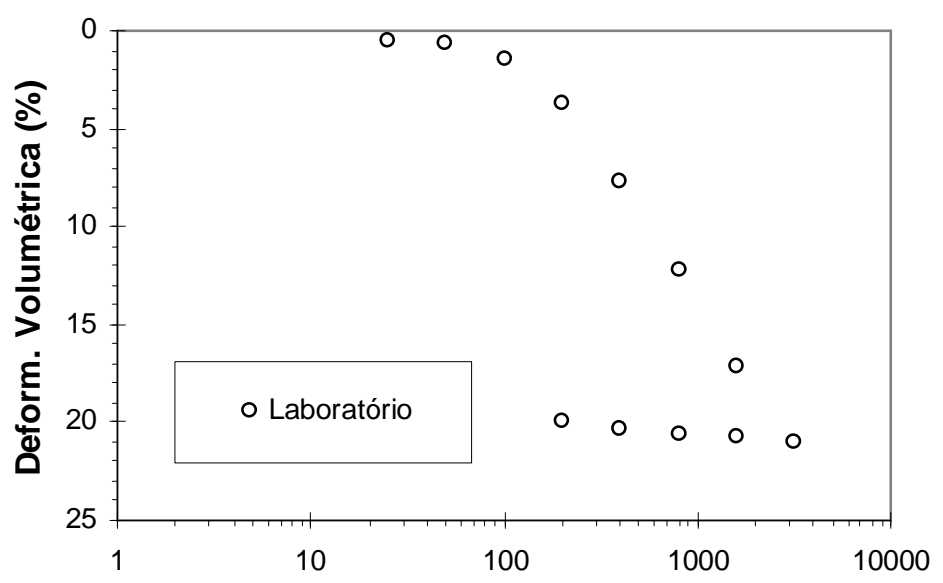

Figura 22 Ensaio edométrico - AP2.

Tensão Vertical (kPa)

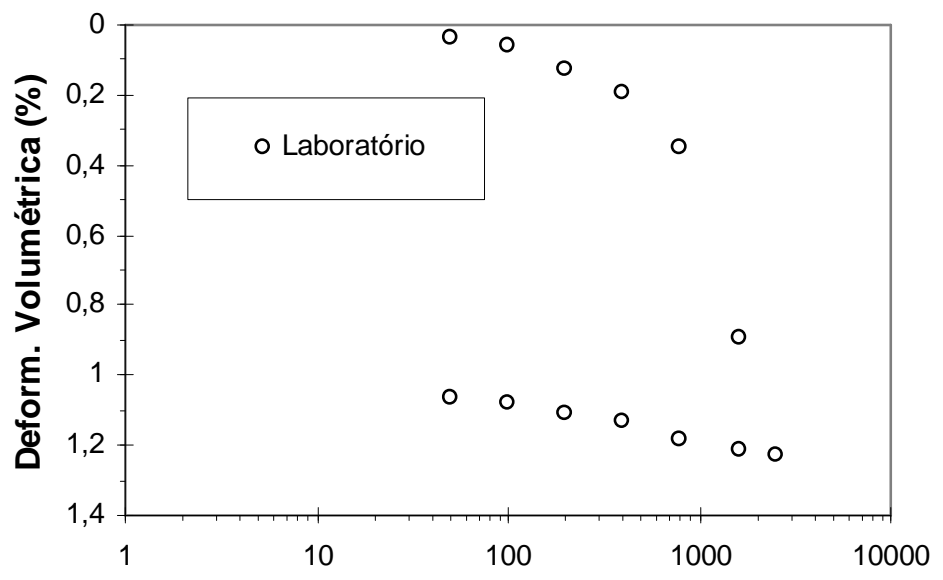

Figura 23 Ensaio edométrico - AV.

A aplicação do Método de Casagrande aos resultados dos ensaios edométricos acima apresentados revelou tensões de pré-adensamento iguais a $127,5 \mathrm{kPa}$ para Argila Porosa 1, 196,1kPa para Argila Porosa 2 e 760kPa para Argila Variegada (PARREIRA, 1991).

O teor de umidade $(w)$, o índice de vazios $(e)$, o grau de saturação $(S)$, o peso específico natural $(\gamma)$ e o peso específico das partículas sólidas $\left(\gamma_{S}\right)$ dos solos em estudo são apresentados na Tabela 1. 
Tabela 1 Índices físicos (PARREIRA, 1991).

\begin{tabular}{c|c|c|c}
\hline SOLO & AP1 & AP2 & AV \\
\hline $\boldsymbol{w}(\boldsymbol{\%})$ & $41,5 \pm 0,74$ & $41,0 \pm 0,90$ & $36,5 \pm 1,50$ \\
\hline $\boldsymbol{e}$ & $1,62 \pm 0,06$ & $1,52 \pm 0,04$ & $1,04 \pm 0,02$ \\
\hline $\boldsymbol{S ( \% )}$ & $69,6 \pm 2,4$ & $72,4 \pm 2,2$ & $92,2 \pm 3,1$ \\
\hline $\boldsymbol{\gamma}\left(\mathbf{k N} / \mathbf{m}^{\mathbf{3}}\right)$ & $14,7 \pm 0,3$ & $15,0 \pm 0,4$ & $17,6 \pm 0,2$ \\
\hline $\boldsymbol{\gamma}_{\boldsymbol{S}}\left(\mathbf{k N} / \mathbf{m}^{\mathbf{3}}\right)$ & 27,2 & 26,8 & 26,3 \\
\hline
\end{tabular}




\section{ANÁLISES NUMÉRICAS REALIZADAS}

As análises numéricas apresentadas neste capítulo foram todas realizadas utilizando um consagrado programa de elementos finitos, criado especificamente para abordagem de problemas geotécnicos, o Imperial College Finite Element Program (ICFEP). Desenvolvido nos últimos trinta anos pelo Professor David M. Potts no Imperial College de Londres, tem sido utilizado e continuamente implementado por inúmeros trabalhos de pesquisa envolvendo fundações, aterros, encostas e escavações, e aplicado com sucesso em importantes projetos de engenharia na Europa. Sua abrangente formulação, associada à adoção de uma forma acelerada do Método Newton-Raphson Modificado para resolução de equações não lineares (POTTS \& ZDRAVKOVIC, 1999), permite que uma vasta gama de problemas geotécnicos seja contemplada, incluindo aqueles que envolvem ações dinâmicas, com a opção de se adotar um número expressivo de modelos constitutivos.

A escavação do Túnel Paraíso foi analisada numericamente adotando-se três modelos constitutivos distintos: o elasto perfeitamente plástico com critério de ruptura de MohrColoumb, o Cam-Clay Modificado e o Cinemático com Duas Superfícies Modificado do Imperial College. Este último, o mais complexo dos três, de desenvolvimento recente, é tema da próxima seção, onde há apresentação de seus principais conceitos (por ser uma extensão do Cam-Clay Modificado, há ainda descrição das características deste modelo).

Foram programadas análises tridimensionais com todos os modelos constitutivos acima citados, mas, infelizmente, a análise 3D adotando o modelo Cinemático com Duas Superfícies Modificado não vingou. Logo no início de seu processamento, foi verificado que o número de interações necessárias para obtenção da convergência em cada incremento era elevadíssimo, superando o limite normalmente estabelecido de 200 interações, o que inviabilizou a obtenção de resultados dentro do período reservado para a realização das modelagens numéricas no Imperial College. São apresentados, no entanto, resultados de uma análise bidimensional com este modelo (juntamente com os resultados obtidos das análises tridimensionais adotando os modelos elasto perfeitamente plástico e Cam-Clay Modificado). 


\subsection{O MODELO CAM-CLAY MODIFICADO E O CINEMÁTICO COM DUAS SUPERFÍCIES MODIFICADO DO IMPERIAL COLLEGE}

O Cam-Clay Modificado é um modelo constitutivo elasto-plástico com endurecimento isotrópico, desenvolvido por Roscoe \& Burland (1968) a partir de resultados de ensaios triaxiais de carregamento. Baseado no estado crítico, suas principais hipóteses são (a leitura deve ser acompanhada da visualização das Figuras 24 e 25):

i) Se uma amostra de argila normalmente consolidada é comprimida isotropicamente, seguirá a linha de compressão isotrópica, assumida como reta no espaço $v$-ln $p$ ' (onde $v$ é o volume específico, igual a $1+e$ (sendo $e$ o índice de vazios), e $p$ ' é a tensão efetiva média), definida pela equação:

$v=N-\lambda \cdot \ln p^{\prime}$

onde $N$ é o volume específico da linha de compressão isotrópica para $p^{\prime}=1 \mathrm{kPa}$ e $\lambda$ é a inclinação desta mesma linha no espaço $v-\ln p$ '.

Se a mesma amostra é em seguida isotropicamente descomprimida, percorrerá a linha de descompressão, assumida como reta no espaço $v-\ln p$ ', descrita pela equação:

$v=v_{\kappa}-\kappa \cdot \ln p^{\prime}$

onde $v_{\kappa}$ é o volume específico da linha de descompressão para $p^{\prime}=1 \mathrm{kPa}$ e $\kappa$ é a inclinação desta mesma linha no espaço $v-\ln p$ '.

ii) Quando cisalhados, todos os solos em última análise atingem o estado crítico, em que grandes distorções cisalhantes ocorrem sem alterações das tensões e do volume específico. A linha do estado crítico é definida no espaço $v-\ln p^{\prime}-q$ (onde $q$ é a tensão desviadora), sendo suas projeções no espaço $q-p^{\prime}$ e no espaço $v-\ln p$ ' definidas respectivamente pelas fórmulas:

$q=M \cdot p^{\prime}$ 
$v=\Gamma-\lambda \cdot \ln p$

onde $M$ é a inclinação da linha do estado crítico no espaço $q-p$ ' e $\Gamma$ é o volume específico desta mesma linha para $p^{\prime}=1 \mathrm{kPa}$.

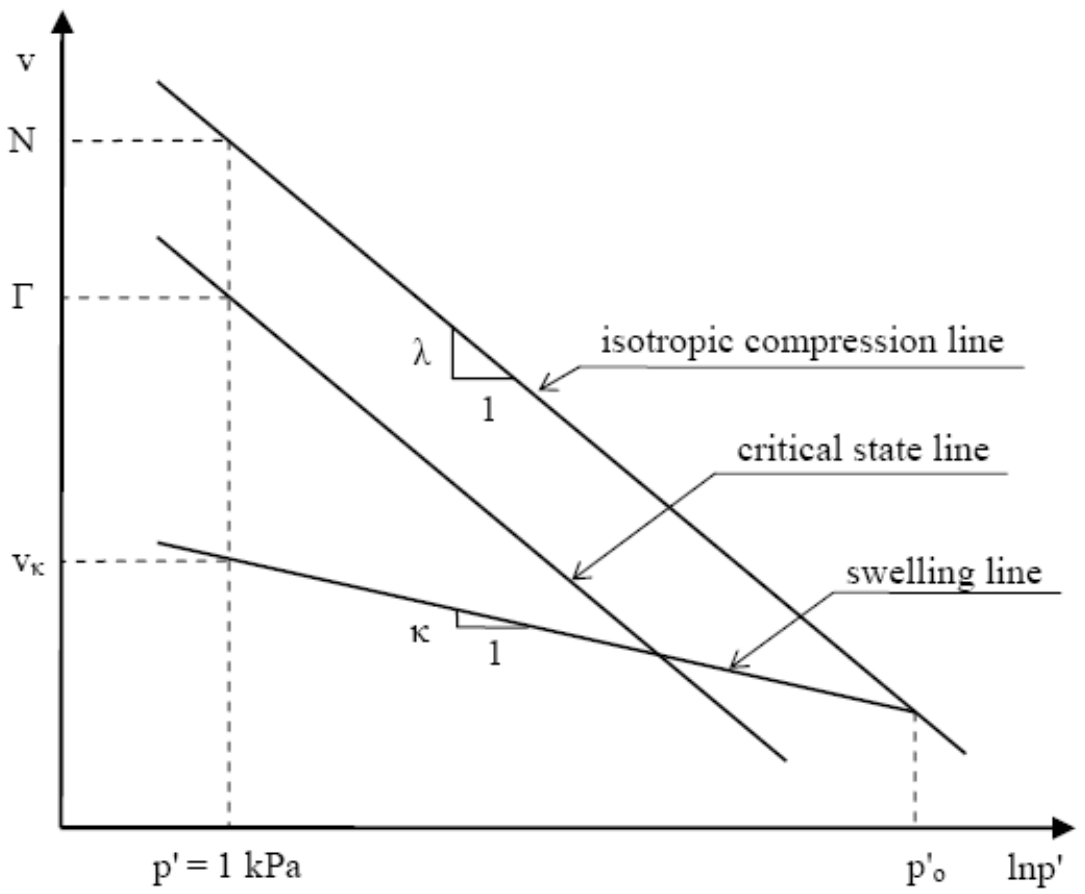

Figura 24 Espaço $v-\ln p$ ': linha de compressão isotrópica (isotropic compression line), linha de descompressão (swelling line) e projeção da linha do estado crítico (critical state line).

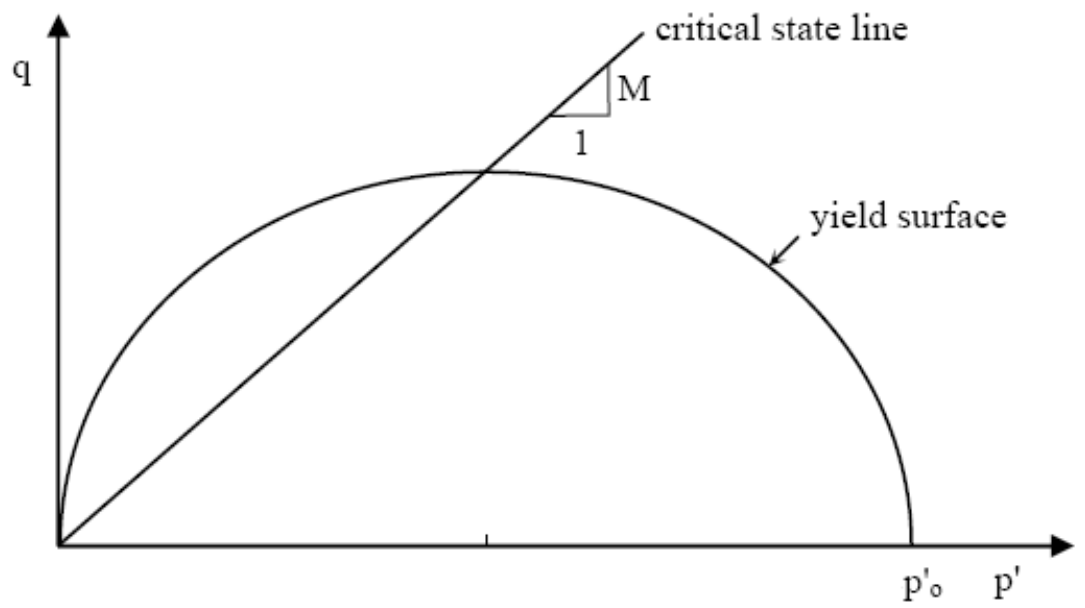

Figura 25 Espaço $q-p$ ': projeção da linha do estado crítico (critical state line) e projeção da superfície de plastificação (yield surface). 
A projeção no espaço $q-p$ ' da superfície de plastificação corrente, isto é, referente à solicitação até então realizada (carregamento e descarregamento isotrópico), com formato elíptico, é descrita pela equação:

$q^{2} / p^{\prime 2}+M^{2} \cdot\left(1-p^{\prime}{ }_{0} / p^{\prime}\right)=0$

onde $p^{\prime}{ }_{0}$ é valor da maior tensão efetiva média a que o solo já esteve submetido.

Caso a amostra em questão venha a sofrer nova compressão isotrópica, percorrerá a linha de descompressão no sentido contrário, até atingir novamente a linha de compressão isotrópica. Se esta compressão persiste, passa a seguir a linha de compressão isotrópica, adquirindo valores cada vez maiores de $p^{\prime}{ }_{0}$. O comportamento é essencialmente elástico ao longo do trajeto na linha de descompressão/recompressão, uma vez que ocorre dentro da superfície de plastificação, mas ao se atingir a linha de compressão isotrópica, toca-se a superfície de plastificação e o regime passa a ser elasto-plástico, havendo aumento da superfície de plastificação, já que $p^{\prime}{ }_{0}$ adquire valores cada vez maiores (no trajeto pela linha de compressão isotrópica). Para cada valor de $p^{\prime}{ }_{0}$ alcançado há uma superfície de plastificação correspondente, sendo que no espaço $v-\ln p^{\prime}-q$ o conjunto destas elipses define uma superfície denominada superfície limite de estado (Figura 26).

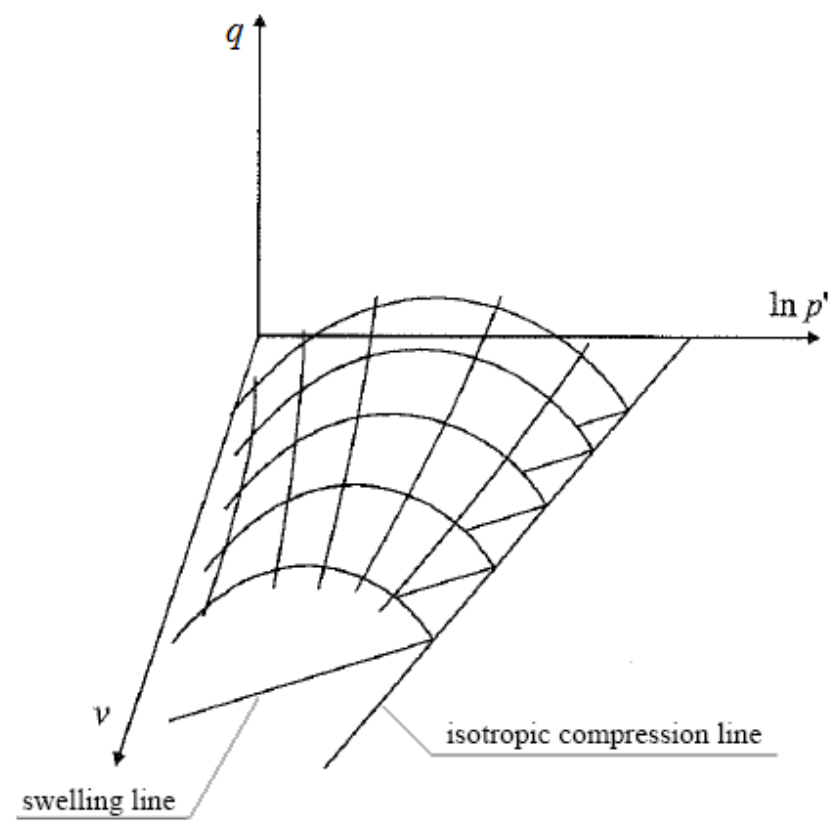

Figura 26 Superfície limite de estado (state boundary surface). 
iii) Quando uma amostra de argila é cisalhada, sua trajetória de tensões seguirá em direção à superfície limite de estado e, assim que tocá-la, percorrerá tal superfície até atingir a linha do estado crítico. $\mathrm{O}$ estado do solo, definido pelas variáveis $p^{\prime}, q$ e $v$, sempre se situa, portanto, dentro ou na própria superfície limite de estado, nunca podendo estar fora dela.

iv) O comportamento da amostra dentro da superfície limite de estado é assumido ser elástico, o que significa que apenas deformações recuperáveis ocorrem. Na superfície limite de estado, o comportamento é elasto-plástico, com o desenvolvimento de deformações recuperáveis (elásticas) e irrecuperáveis (plásticas).

Solos sobreadensados por descarregamento ou por ação de intempéries são caracterizados por estados de tensões dentro da superfície limite de estado. Quando cisalhados, comportamento elástico ocorre até o estado de tensão atingir tal superfície. A partir do momento que a superfície de estado é tocada, regime elasto-plástico é previsto.

A rigidez volumétrica elástica $(K)$ no Cam-Clay Modificado é relacionada à tensão efetiva média $(p$ ’) e ao volume específico $(v)$ conforme a equação:

$$
K=\frac{v p^{\prime}}{\kappa}
$$

E a rigidez cisalhante elástica, representada por $G$, relaciona-se com $K$ através do coeficiente de Poisson $(\mu)$ :

$$
\frac{G}{K}=\frac{3(1-2 \mu)}{2(1+\mu)}
$$

Em suma, o Cam-Clay Modificado é definido por cinco parâmetros:

- volume específico da linha de compressão isotrópica para $p^{\prime}=1 \mathrm{kPa}(N)$;

- inclinação da linha de compressão isotrópica no espaço $v-\ln p^{\prime}(\lambda)$;

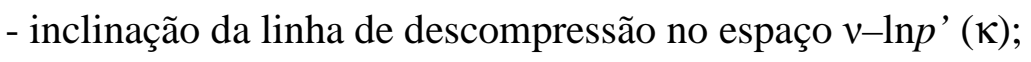

- rigidez cisalhante elástica $(G)$ ou coeficiente de Poisson $(\mu)$; 
- inclinação da linha do estado crítico no espaço $q-p^{\prime}(M)$.

O modelo constitutivo Cinemático com Duas Superfícies Modificado do Imperial College (GRAMMATIKOPOULOU, 2004) representa um aprimoramento do modelo Cinemático com Duas Superfícies, desenvolvido por Al-Tabbaa (1987). Este último, uma extensão do CamClay Modificado (modelo empregado com sucesso na previsão do comportamento de argilas normalmente consolidadas), é voltado ao comportamento de argilas sobreadensadas, reconhecidamente não linear e inelástico, exceto a baixíssimas deformações, em que a rigidez é praticamente constante. Desta maneira, introduz uma superfície de plastificação cinemática dentro da superfície limite do modelo Cam-Clay Modificado (menor, mas com o mesmo formato que a superfície externa, conforme indicado na Figura 27), motivo pelo qual é também conhecido por Modelo da Bolha (Bubble Model), que permite a representação desta característica não linear e inelástica das argilas sobreadensadas a partir dos primeiros estágios de carregamento, diferentemente do Cam-Clay Modificado, que para estas argilas prevê um mais longo intervalo em regime elástico, em função da maior distância percorrida para se atingir a superfície de plastificação.

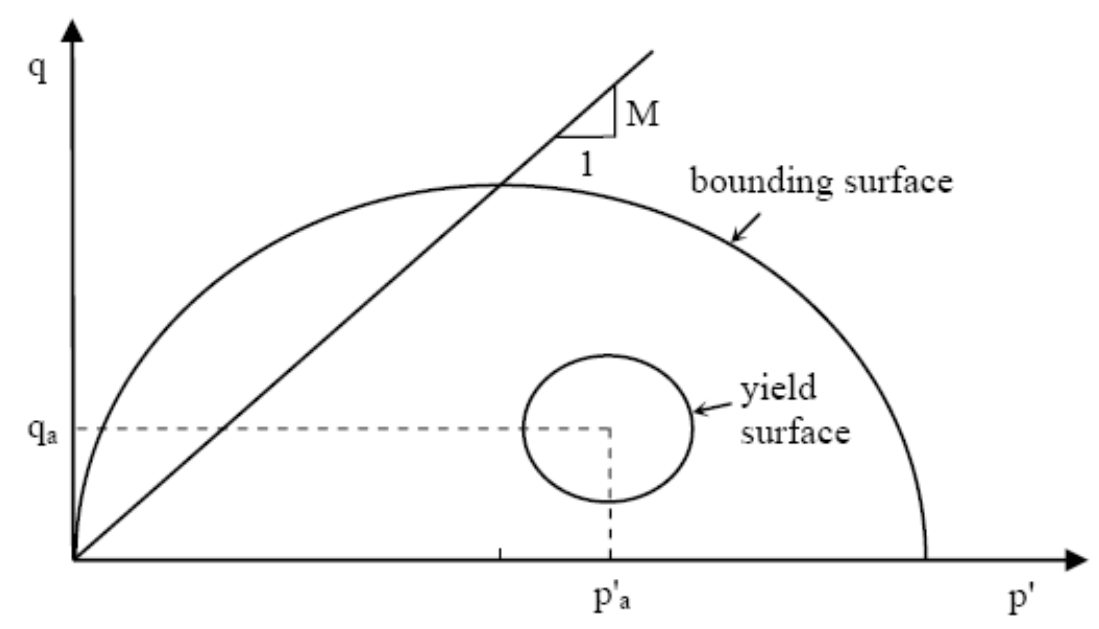

Figura 27 Projeção da superfície de plastificação cinemática (yield surface) e da superfície limite (bounding surface) no espaço $q-p$ '.

A equação da superfície de plastificação cinemática, dentro da qual se observa comportamento puramente elástico, é apresentada a seguir: 
$\left(p^{\prime}-p_{a}^{\prime}\right)^{2}+\frac{\left(q-q_{a}\right)^{2}}{M^{2}}=R^{2} p_{o}^{\prime 2}$

onde $R$ é a razão entre o tamanho da superfície de plastificação cinemática e o tamanho da superfície limite, determinada por tentativa e erro durante a reprodução numérica de ensaios, e ( $\left.p_{\mathrm{a}}^{\prime}, q_{\mathrm{a}}\right)$ é o centro da superfície de plastificação cinemática.

As alterações na superfície limite ocorrem através de endurecimento isotrópico, significando que tal superfície expande ou contrai durante a plastificação (assim como a superfície limite do Cam-Clay Modificado). Já com relação à superfície de plastificação cinemática, sua evolução, ocorrida assim que ela é tocada pelo estado de tensão corrente, é definida por uma combinação de endurecimento cinemático e isotrópico, o que significa que ela translada no espaço de tensões, acompanhando a alteração do estado de tensão corrente, e simultaneamente expande ou contrai. As duas superfícies do modelo podem entrar em contato, mas nunca se interceptam, o que é garantido pelo fato do centro da superfície de plastificação cinemática se mover sempre ao longo do vetor $\beta$, que associa o estado de tensões corrente, $\mathrm{C}$, a seu conjugado ponto, D, na superfície limite (Figura 28). O ponto conjugado D é definido como o ponto na superfície limite que possui vetor normal com mesma direção e sentido do vetor normal do ponto $\mathrm{C}$ na superfície de plastificação cinemática.

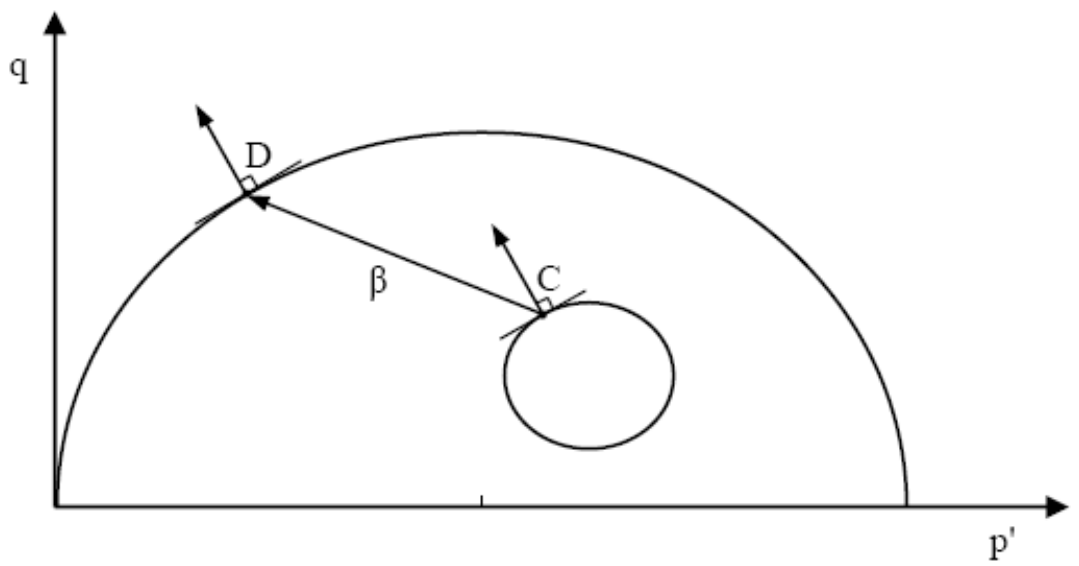

Figura 28 Indicação do vetor $\beta$.

O vetor $\beta$ é dado por: 
$\beta=\left\{\begin{array}{c}\frac{p^{\prime}-p_{a}^{\prime}}{R}-\left(p^{\prime}-p_{o}^{\prime}\right) \\ \frac{q-q_{a}}{R}-q\end{array}\right\}$

O modelo prevê alteração simultânea das duas superfícies a partir do momento que o estado de tensão corrente atinge a superfície de plastificação cinemática (assim que isto ocorre, a superfície limite também é tocada, através do vetor $\beta$, e também inicia sua evolução, conforme indica a Figura 29) e alteração exclusiva da superfície limite assim que a superfície de plastificação cinemática a atinge de fato.

O módulo de endurecimento, $A$, quando a superfície de plastificação cinemática se move dentro da superfície limite, é dado pela seguinte expressão (versão do modelo Cinemático com Duas Superfícies, desenvolvido por Al-Tabbaa (1987)):

$$
\begin{array}{r}
A=\frac{4}{\lambda-\kappa}\left[\left(p^{\prime}-p_{a}^{\prime}\right)\left[p_{a}^{\prime}\left(p^{\prime}-p_{a}^{\prime}\right)+\frac{1}{2}\left(\frac{\partial F_{y}}{\partial s}: s_{a}\right)+\frac{R^{2} p_{o}^{\prime 2}}{4}\right]+\right. \\
\left.\left(\frac{b}{b_{\max }}\right)^{\psi}\left(\frac{p_{o}^{\prime}}{2}\right)^{3}\right]
\end{array}
$$

onde $b$ é a distância entre a superfície de plastificação cinemática e a superfície limite, e $\psi$ é um expoente com valor positivo determinado experimentalmente (por tentativa e erro durante a reprodução numérica de ensaios).

A versão do módulo $A$, para esta mesma situação, proposta pelo modelo Cinemático com Duas Superfícies Modificado do Imperial College (GRAMMATIKOPOULOU, 2004) garante uma mais suave transição elasto-plástica quando o estado de tensão atinge a superfície de plastificação cinemática e o regime muda de puramente elástico para elasto-plástico, e é descrita a seguir: 


$$
\begin{array}{r}
A=\frac{4}{\lambda-\kappa}\left[\left(p^{\prime}-p_{a}^{\prime}\right)\left[p_{a}^{\prime}\left(p^{\prime}-p_{a}^{\prime}\right)+\frac{1}{2}\left(\frac{\partial F_{y}}{\partial s}: s_{a}\right)+\frac{R^{2} p_{o}^{\prime 2}}{4}\right]+\right. \\
\left.\alpha\left(\frac{b}{b_{\max }-b}\right)\left(\frac{p_{o}^{\prime}}{2}\right)^{3} R^{2}\right]
\end{array}
$$

onde $\alpha$ é um parâmetro que controla a taxa de degradação da rigidez, que, assim como o $\psi$ do Cinemático com Duas Superfície, não pode ser obtido diretamente de dados de ensaios, sendo determinado por tentativa e erro durante a reprodução numérica destes.

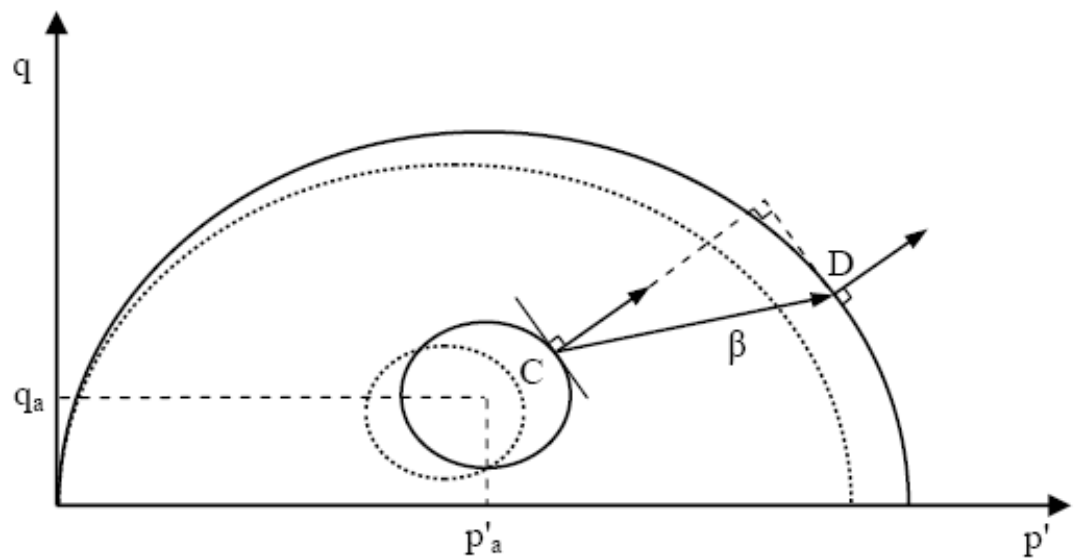

Figura 29 Evolução simultânea das duas superfícies.

Quando as duas superfícies entram em contato de fato, o módulo de endurecimento $A$ reduz-se ao módulo de endurecimento do Cam-Clay Modificado (tanto no modelo desenvolvido por Al-Tabbaa, 1987, quanto no proposto por Grammatikopoulou, 2004):

$A=\frac{4}{\lambda-\mathcal{K}}\left[\left(p^{\prime}-\frac{p_{0}^{\prime}}{2}\right) p^{\prime} \frac{p_{0}^{\prime}}{2}\right]$

Se a trajetória de tensões permanece dentro da superfície de plastificação cinemática, o comportamento é puramente elástico, sendo os parâmetros elásticos $K$ e $G$, respectivamente a rigidez volumétrica e a rigidez cisalhante, definidos da mesma maneira como no modelo Cam-Clay Modificado. 
Em suma, o modelo Cinemático com Duas Superfícies Modificado do Imperial College é definido por sete parâmetros, sendo os cinco primeiros comuns ao Cam-Clay Modificado:

- volume específico da linha de compressão isotrópica para $p^{\prime}=1 \mathrm{kPa}(N)$;

- inclinação da linha de compressão isotrópica no espaço $v-\ln p^{\prime}(\lambda)$;

- inclinação da linha de descompressão no espaço $v-\ln p^{\prime}(\kappa)$;

- rigidez cisalhante elástica $(G)$ ou coeficiente de Poisson $(\mu)$;

- inclinação da linha do estado crítico no espaço $q-p^{\prime}(M)$;

- razão entre o tamanho da superfície de plastificação cinemática e o tamanho da superfície limite $(R)$;

- parâmetro que controla a taxa de degradação da rigidez $(\alpha)$.

\subsection{OBTENÇÃO DOS PARÂMETROS DOS SOLOS}

A determinação dos parâmetros dos solos do local da escavação do Túnel Paraíso, segundo cada modelo constitutivo adotado, se deu através de reprodução de ensaios no ICFEP, empregando malha bidimensional com um só elemento (de dimensões unitárias, munido com oito nós) e condições de carregamento e contorno pertinentes com cada ensaio. Esta etapa de reprodução numérica de ensaios, além de ter servido para obtenção de parâmetros, mostrou-se útil por destacar a habilidade (ou limitação) de cada modelo constitutivo na representação do comportamento dos materiais.

A começar pelo modelo elasto perfeitamente plástico com critério de ruptura de MohrColoumb, a determinação dos parâmetros dos materiais foi realizada mediante a reprodução dos ensaios triaxiais drenados de compressão por carregamento apresentados no capítulo 3 . Partindo de valores de parâmetros adotados por Parreira (1991), apresentados na Tabela 2, foram iniciadas as reproduções numéricas, acompanhadas de ajustes em alguns valores, de maneira que o desempenho final do modelo constitutivo na representação dos ensaios dos materiais pode ser observado nas Figuras 30 a 35. Os parâmetros definitivos, correspondentes ao desempenho apresentado nestas figuras, aparecem na Tabela 3 (a este grupo de parâmetros é dado o nome de Mohr-Coloumb I). 
Tabela 2 Parâmetros de partida (PARREIRA, 1991).

\begin{tabular}{c|c|c|c|c|c}
\cline { 2 - 6 } & $\boldsymbol{c}^{\prime}(\mathbf{k P a})$ & $\boldsymbol{\phi}^{\prime}\left({ }^{\mathbf{0}}\right)$ & $\boldsymbol{E}_{\mathbf{5 0}}(\mathbf{k P a})$ & $\boldsymbol{\psi}^{\prime}\left(^{\mathbf{0}}\right)$ & $\boldsymbol{\mu}$ \\
\hline $\mathbf{A P 1}$ & 35,4 & 23,3 & 4000 & 0 & 0,27 \\
\hline $\mathbf{A P 2}$ & 39,8 & 27,2 & 6000 & 0 & 0,27 \\
\hline $\mathbf{A V}$ & 66,2 & 25,0 & 120000 & 0 & 0,17 \\
\hline
\end{tabular}

Tabela 3 Parâmetros definitivos - Mohr-Coloumb I.

\begin{tabular}{c|c|c|c|c|c}
\cline { 2 - 6 } & $\boldsymbol{c}^{\prime}(\mathbf{k P a})$ & $\boldsymbol{\phi}^{\boldsymbol{\prime}}\left(^{\mathbf{0}}\right)$ & $\boldsymbol{E}_{\boldsymbol{5 0}}(\mathbf{k P a})$ & $\boldsymbol{\psi}^{\boldsymbol{\prime}}\left(^{\mathbf{0}}\right)$ & $\boldsymbol{\mu}$ \\
\hline AP1 & 42 & 23,3 & 4600 & 0 & 0,27 \\
\hline AP2 & 39,8 & 27,2 & 6400 & 0 & 0,27 \\
\hline AV & 74 & 25,0 & 107600 & 0 & 0,17 \\
\hline
\end{tabular}

onde c' é a coesão efetiva, $\phi$ ' é o ângulo de atrito em termos de tensões efetivas, $E_{50}$ é o módulo secante correspondente a $50 \%$ da tensão desviadora na ruptura, $\psi$ ' é o ângulo de dilatância e $\mu$ é o coeficiente de Poisson. 

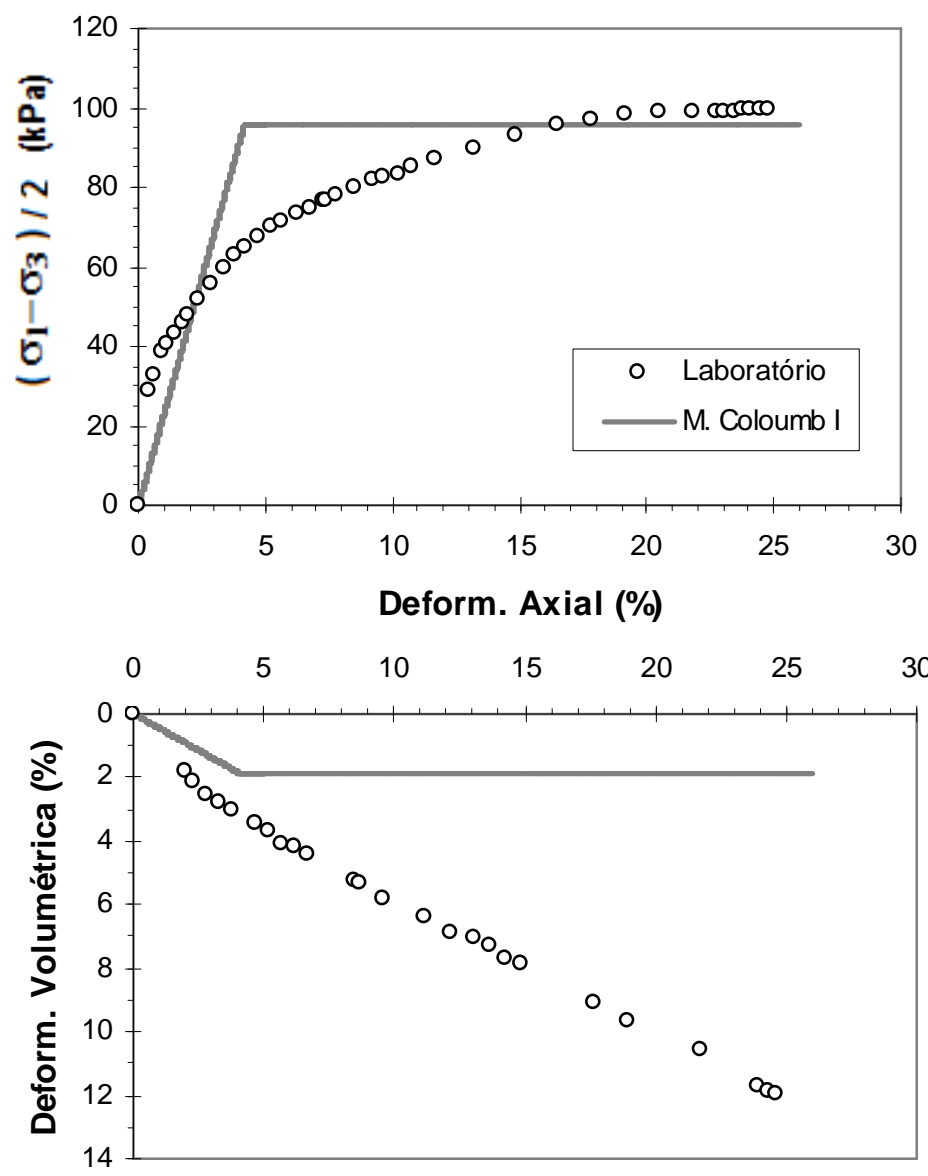

Figura 30 Reprodução numérica do ensaio triaxial drenado de compressão por carregamento $-\mathrm{AP} 1\left(\sigma_{3}=49 \mathrm{kPa}\right)-$ Mohr-Coloumb I.

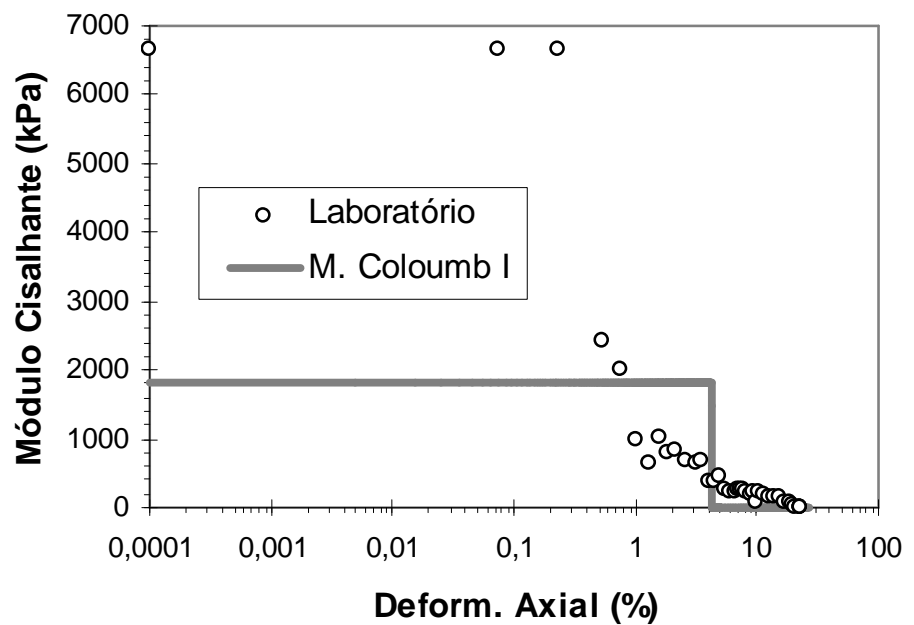

Figura 31 Variação do módulo de rigidez cisalhante conseguida com a reprodução numérica do ensaio triaxial acima - AP1 - Mohr-Coloumb I. 

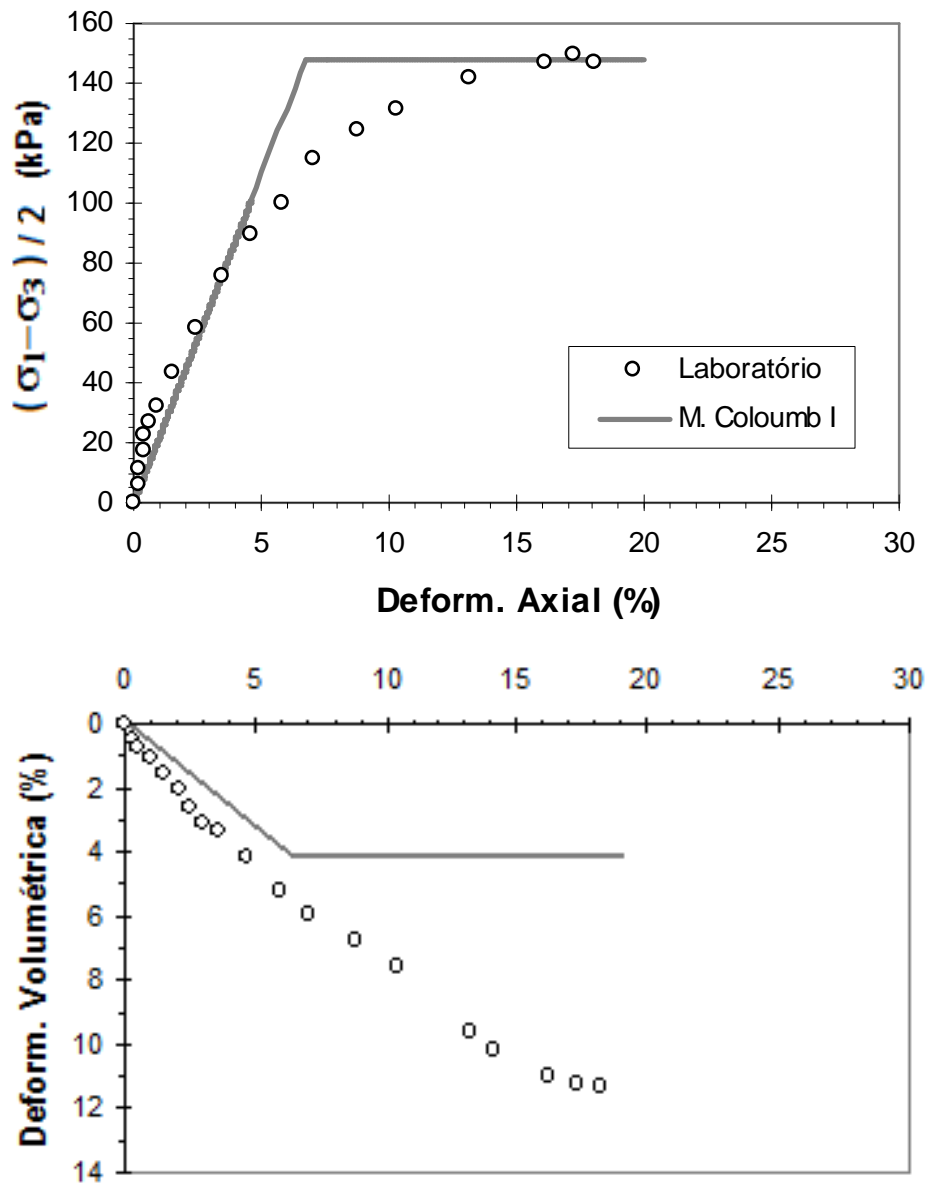

Figura 32 Reprodução numérica do ensaio triaxial drenado de compressão por carregamento $-\operatorname{AP} 2\left(\sigma_{3}=98,1 \mathrm{kPa}\right)-$ Mohr-Coloumb I.

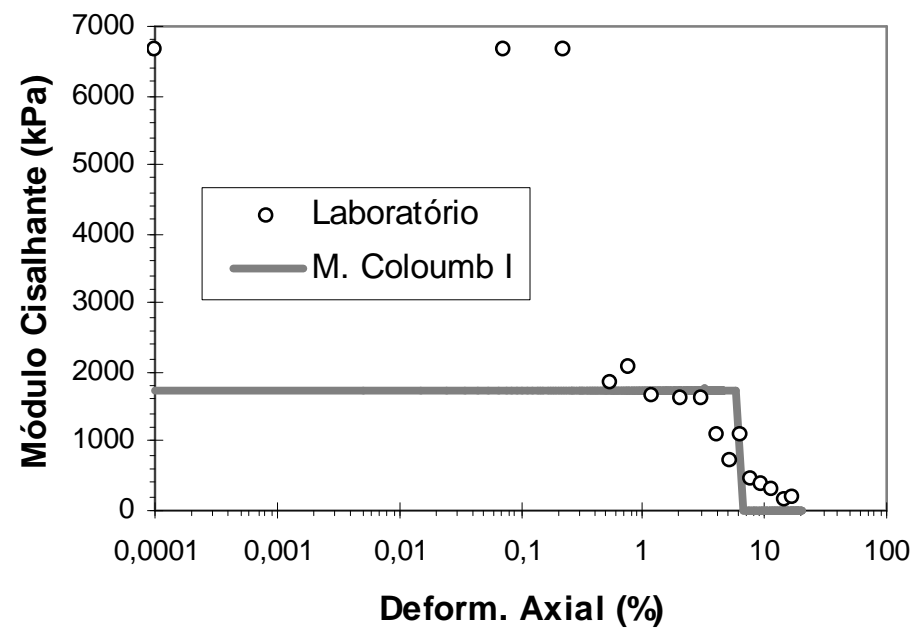

Figura 33 Variação do módulo de rigidez cisalhante conseguida com a reprodução numérica do ensaio triaxial acima - AP2 - Mohr-Coloumb I. 

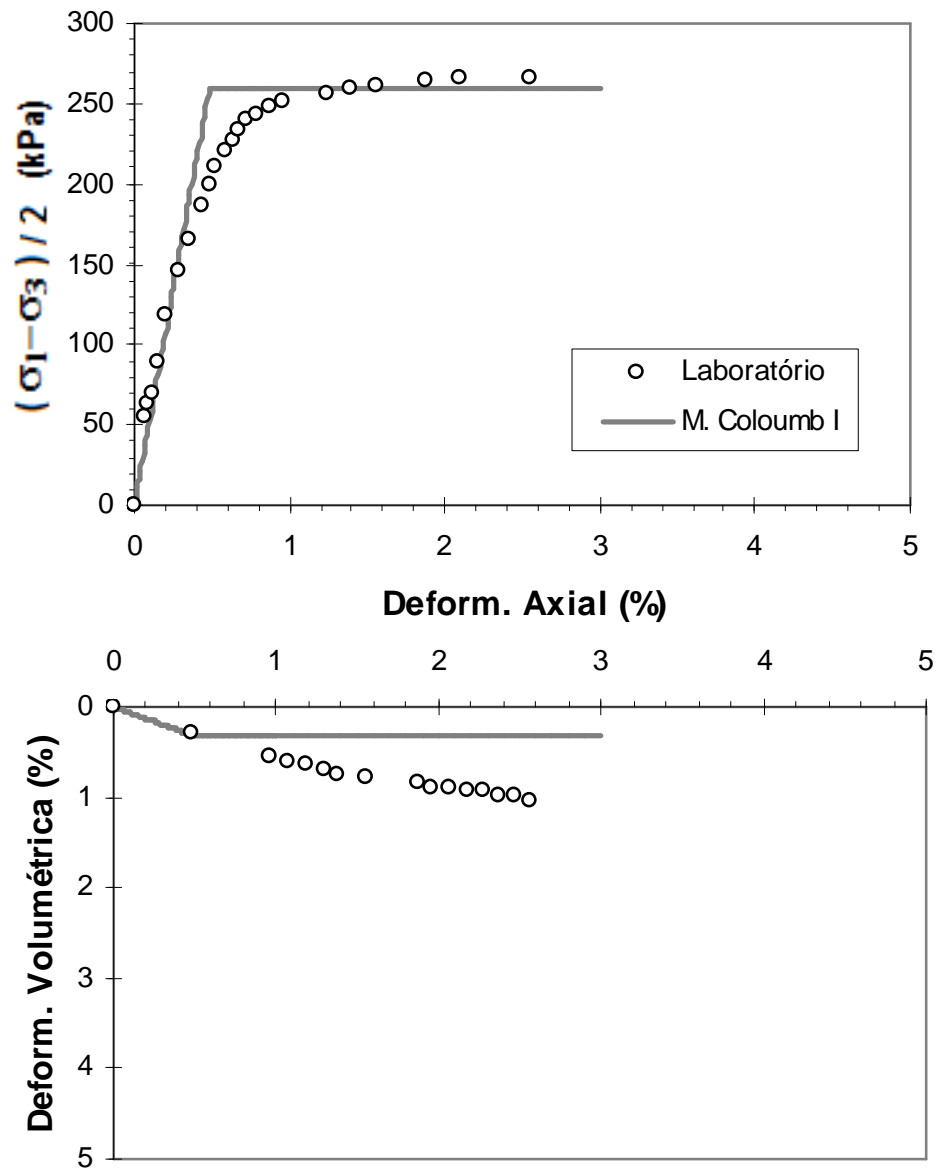

Figura 34 Reprodução numérica do ensaio triaxial drenado de compressão por carregamento - AV $\left(\sigma_{3}=196,1 \mathrm{kPa}\right)$ - Mohr-Coloumb I.

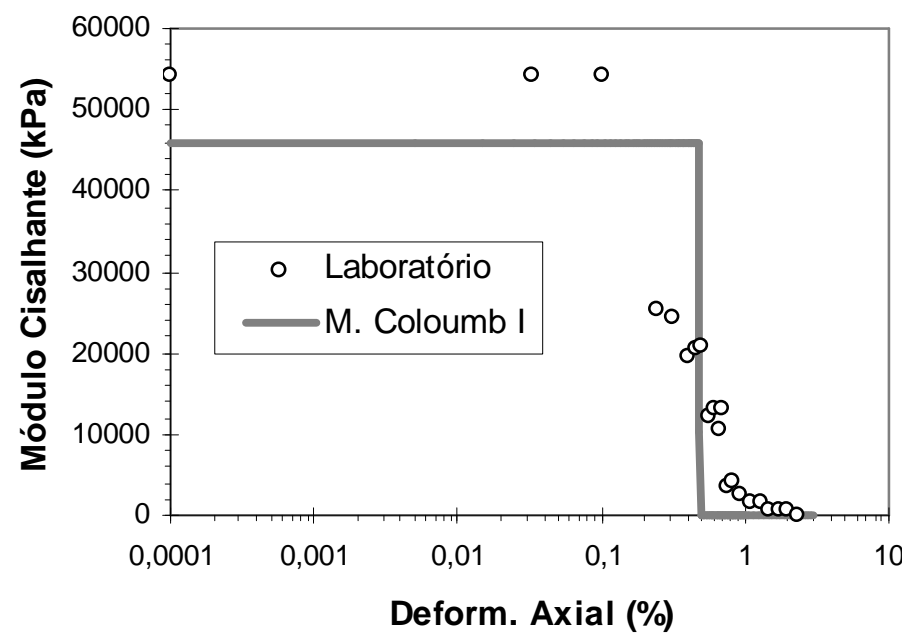

Figura 35 Variação do módulo de rigidez cisalhante conseguida com a reprodução numérica do ensaio triaxial acima - AV - Mohr-Coloumb I. 
Visto que a adoção de um ângulo de dilatância igual a zero, que implica em deformação volumétrica nula durante a plastificação, não representa bem a deformação volumétrica total apresentada pelos materiais, optou-se por realizar mais uma etapa de reprodução de ensaios com o modelo elasto perfeitamente plástico, empregando desta vez ângulos de dilatância negativos, que, conforme demonstram as Figuras 36 a 38, proporcionaram deformações volumétricas mais concordantes com as dos ensaios. O novo conjunto de parâmetros obtido (idêntico ao anterior, com exceção dos valores de ângulo de dilatância), que recebe o nome de Mohr-Coloumb 2, é apresentado na Tabela 4.

Tabela 4 Parâmetros definitivos - Mohr-Coloumb II.

\begin{tabular}{c|c|c|c|c|c}
\cline { 2 - 5 } & $\boldsymbol{c}^{\prime}(\mathbf{k P a})$ & $\boldsymbol{\phi}^{\prime}\left(^{\mathbf{0}}\right)$ & $\boldsymbol{E}_{50}(\mathbf{k P a})$ & $\boldsymbol{\psi}^{\prime}\left(^{\mathbf{0}}\right)$ & $\boldsymbol{\mu}$ \\
\hline $\mathbf{A P 1}$ & 42 & 23,3 & 4600 & -18 & 0,27 \\
\hline $\mathbf{A P 2}$ & 39,8 & 27,2 & 6400 & -30 & 0,27 \\
\hline $\mathbf{A V}$ & 74 & 25,0 & 107600 & -12 & 0,17 \\
\hline
\end{tabular}



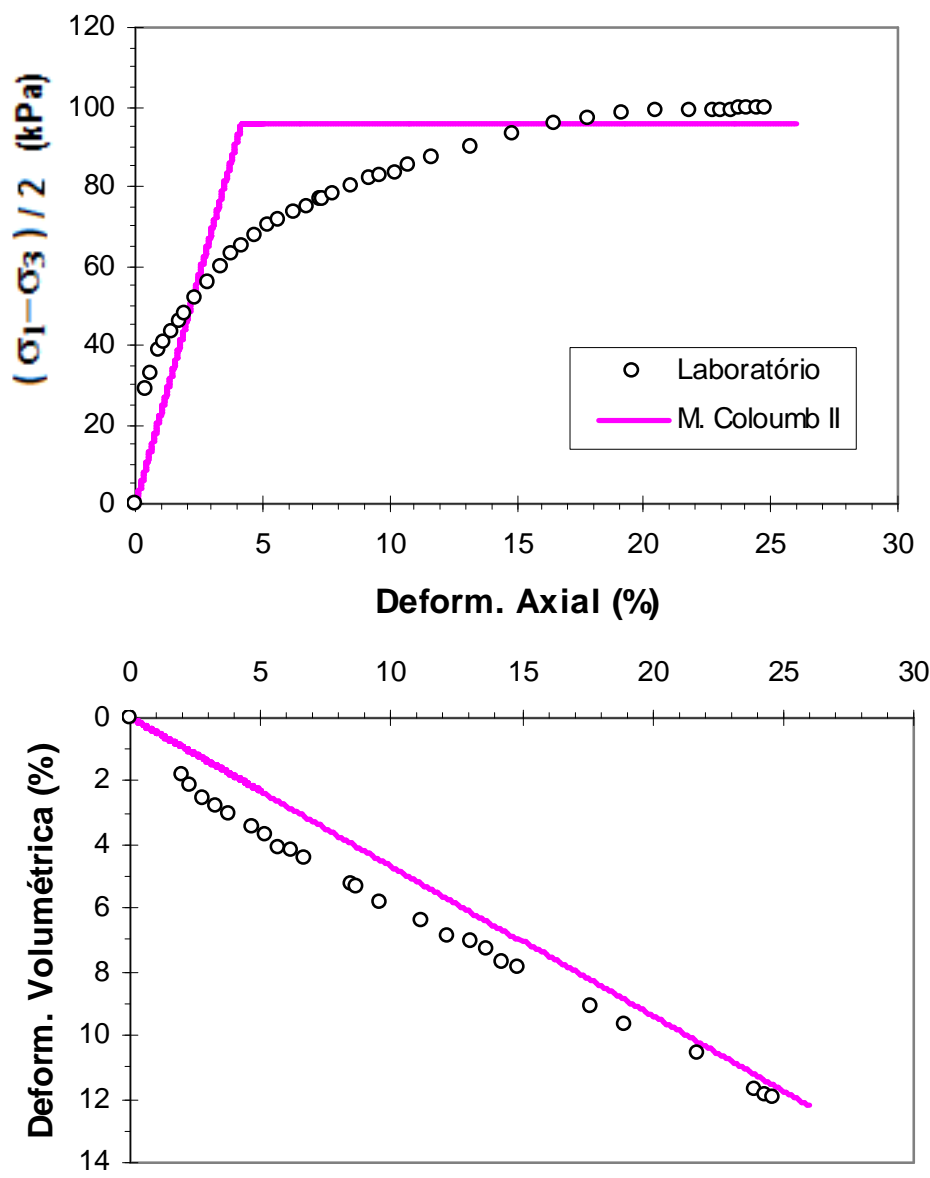

Figura 36 Reprodução numérica do ensaio triaxial drenado de compressão por carregamento $-\operatorname{AP} 1\left(\sigma_{3}=49 \mathrm{kPa}\right)-$ Mohr-Coloumb II. 

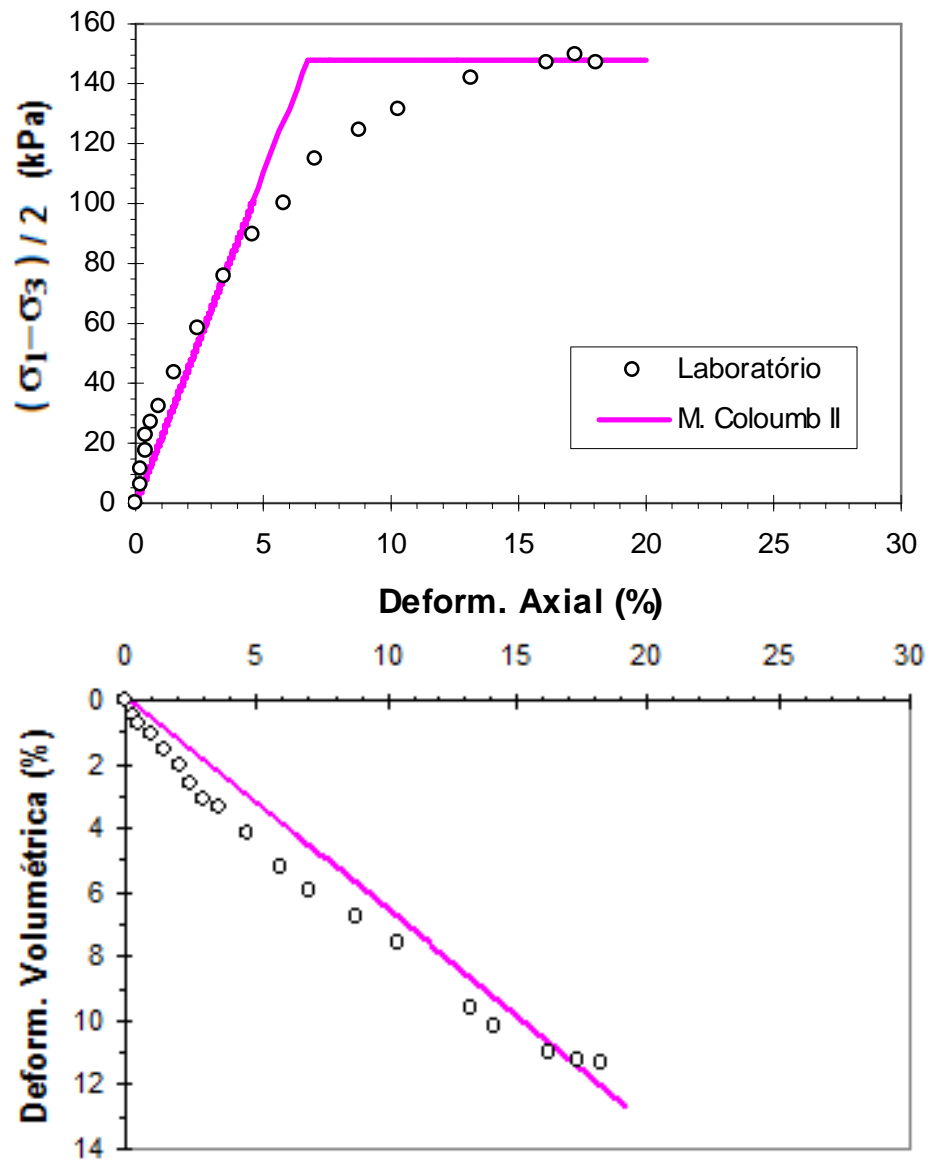

Figura 37 Reprodução numérica do ensaio triaxial drenado de compressão por carregamento $-\mathrm{AP} 2\left(\sigma_{3}=98,1 \mathrm{kPa}\right)-$ Mohr-Coloumb II. 

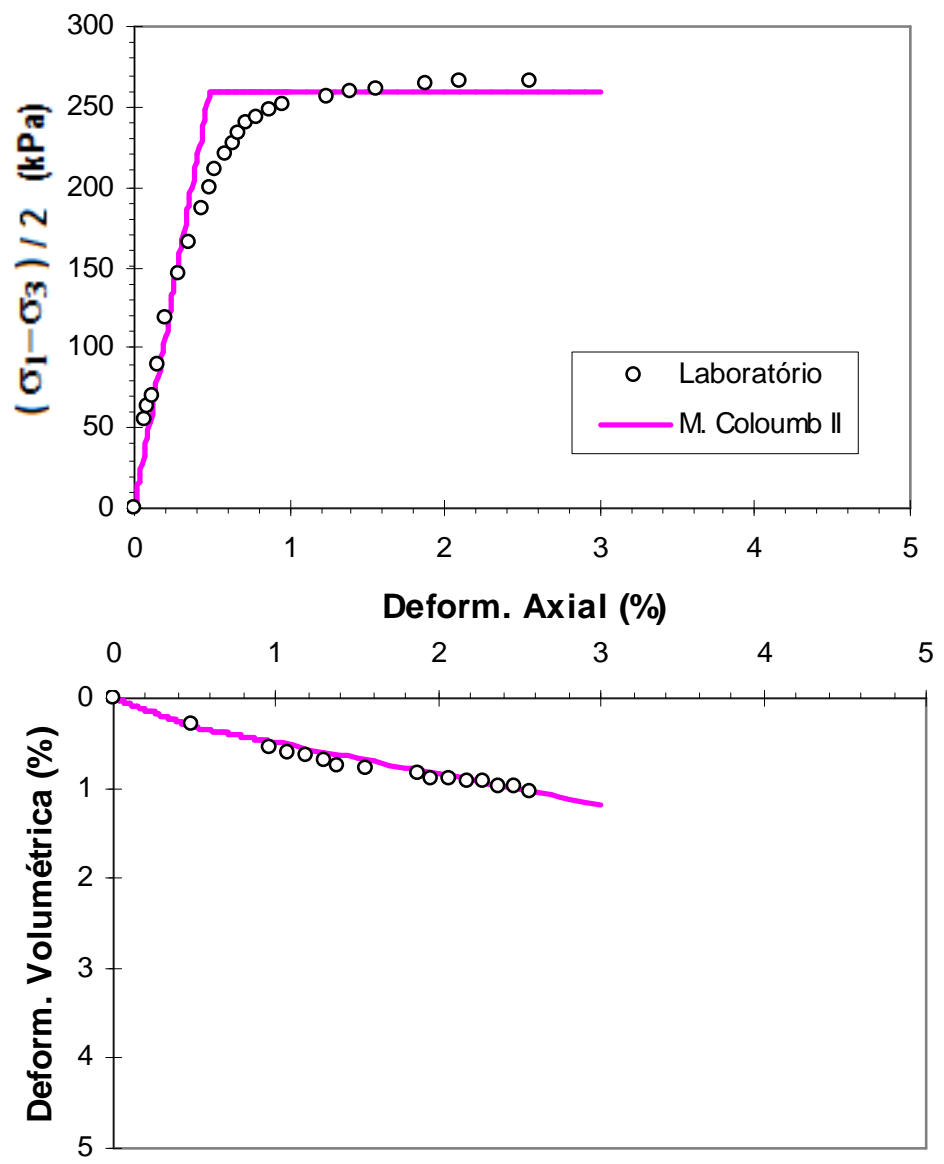

Figura 38 Reprodução numérica do ensaio triaxial drenado de compressão por carregamento - AV $\left(\sigma_{3}=196,1 \mathrm{kPa}\right)-$ Mohr-Coloumb II.

Com relação ao modelo Cam-Clay Modificado, a determinação dos parâmetros dos materiais se baseou nos ensaios triaxiais e edométricos apresentados no capítulo 3. Os parâmetros $N, \lambda$ e $\kappa$, esclarecidos na seção anterior, foram obtidos diretamente dos ensaios edométricos (exibidos em termos de $v$-ln $p^{\prime}$ ), conforme indica a Figura 39, enquanto que o parâmetro $M$, também abordado na seção anterior, foi conseguido a partir da tensão de ruptura de cada ensaio (em termos de $q-p^{\prime}$ ), como mostra a Figura 40. A rigidez cisalhante elástica, $G$, foi calculada da maneira como sugere a Figura 41.

Vale observar que os parâmetros $N, \lambda$ e $\kappa$ mencionados no parágrafo anterior seriam melhor referidos como $N^{*}, \lambda^{*}$ e $\kappa^{*}$, uma vez que não estão relacionados diretamente a ensaios de compressão isotrópica, e sim a ensaios edométricos. O programa ICFEP proporciona ao usuário a possibilidade de processar os modelos constitutivos Cam-Clay Modificado e Cinemático com Duas Superfícies Modificado do Imperial College também com parâmetros 
advindos de ensaios edométricos, como alternativa a uma eventual ausência de ensaios de compressão isotrópica ou na hipótese destes ensaios existirem e não oferecem condições de se distinguirem as inclinações referentes aos parâmetros $\lambda$ e $\kappa$ no espaço $v-\ln p$, o que ocorreu com os ensaios de compressão isotrópica aos quais este estudo teve acesso.

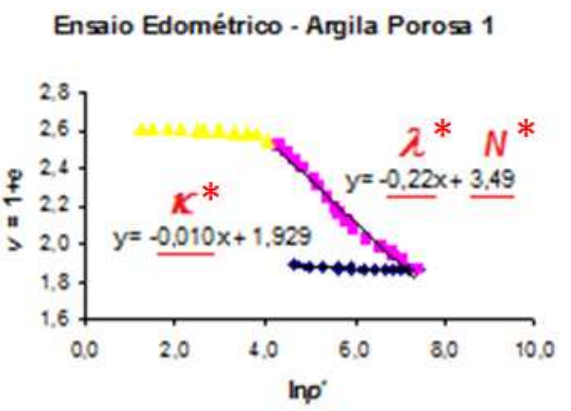

\section{Ensaio Edométrico - Argila Porosa 2}

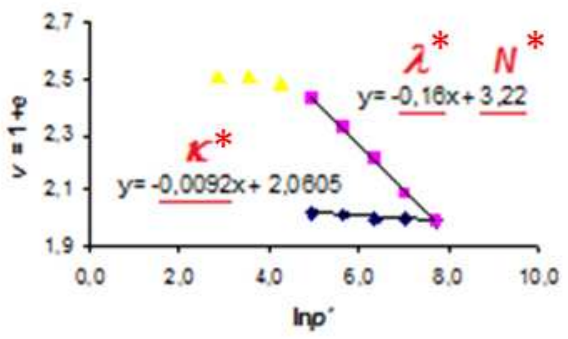

Ensaio Edométrico - Argila Variegada

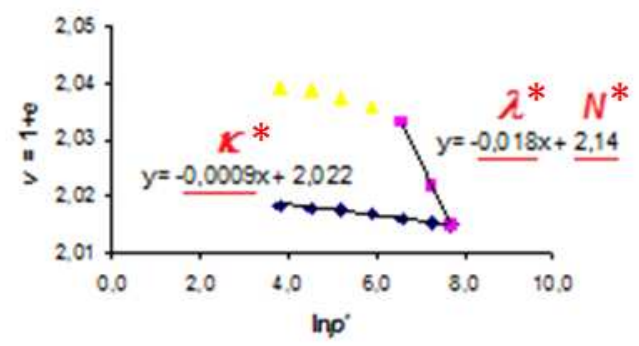

Figura 39 Obtenção dos parâmetros $N^{*}, \lambda^{*}$ e $\kappa^{*}$.

Argila Poross 1

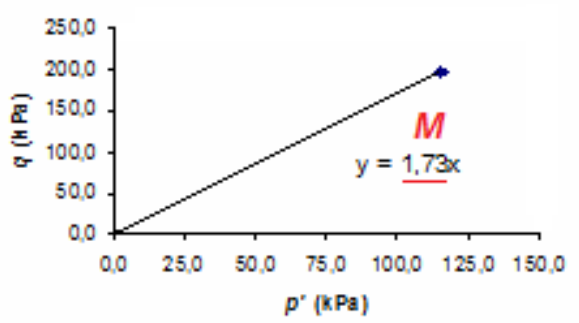

Argila Porosa 2

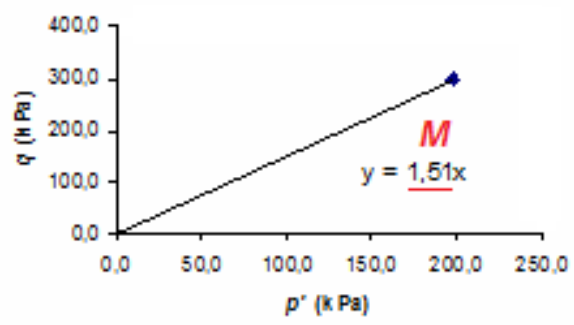

Argila Variegada

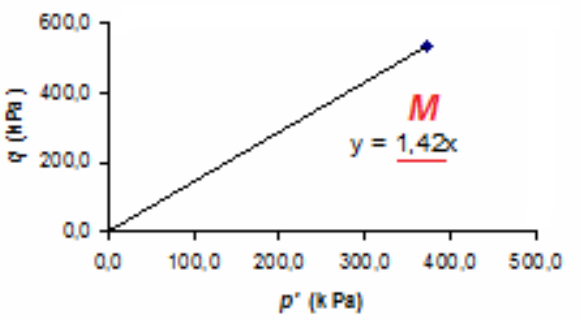

Figura 40 Obtenção do parâmetro $M$. 
A Figura 40 deixa claro que a determinação do parâmetro $M$ para cada solo analisado se baseou apenas em um único ensaio triaxial drenado de compressão por carregamento. Isto se justifica pela constatação deste estudo de que a adoção de um $M$ baseado em mais de um ensaio de compressão por carregamento ( $M$ referente a uma linha do estado crítico considerando mais de um ponto no espaço $q-p^{\prime}$ ), cada qual com uma tensão de confinamento distinta, não levou a uma adequada reprodução numérica de nenhum destes ensaios individualmente. Diante deste fato, optou-se por adotar um único ensaio de compressão por carregamento para determinação do $M$ de cada solo, sendo este ensaio aquele cuja tensão efetiva da fase de confinamento mais se aproximasse da tensão efetiva média geostática (condição de partida dos eventos) da camada do material em questão.

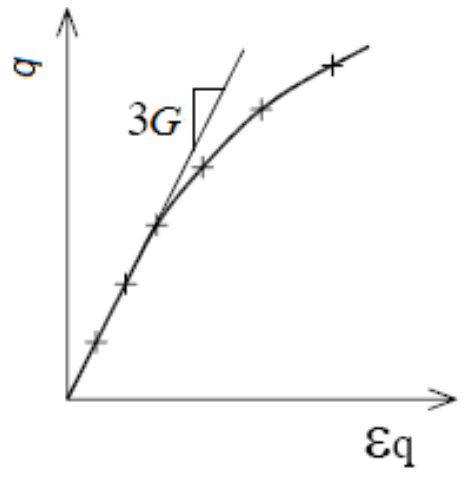

Figura 41 Obtenção da rigidez cisalhante elástica $(G)$.

onde $\varepsilon_{\mathrm{q}}$ é a deformação cisalhante, igual a $\varepsilon_{\mathrm{a}}-\varepsilon_{\mathrm{v}} / 3$ (sendo $\varepsilon_{\mathrm{a}}$ e $\varepsilon_{\mathrm{v}}$ respectivamente a deformação axial e a deformação volumétrica).

Os dados de entrada do Cam-Clay Modificado, que incluem ainda a razão de sobreadensamento em termos de tensões efetivas médias (igual à tensão efetiva média de préadensamento do material $\left(p{ }_{0}\right)$ divida pelo $p$ ' geostático do ponto médio de sua camada no maciço do Túnel Paraíso), OCR, aparecem na Tabela 5. O desempenho deste modelo constitutivo na representação dos ensaios dos materiais pode ser observado nas Figuras 42 a 50 . 
É válido observar que o parâmetro de estado $O C R$ mencionado no parágrafo anterior seria melhor referido como $O C R^{*}$, já que a rigor não é obtido pela divisão de $p^{\prime}{ }_{0}$ pelo $p$ ' geostático do solo, uma vez que $p^{\prime}{ }_{0}$ é uma informação advinda de ensaios de compressão isotrópica (não adotados no presente estudo para obtenção de parâmetros), mas sim pela divisão de $p^{\prime}{ }_{0}{ }^{*}$ pelo p' geostático do solo, sendo $p^{\prime}{ }^{*}{ }^{*}$ a tensão efetiva média referente à intersecção da reta $K_{0}$ (trajetória de tensões de um ensaio edométrico) com a superfície limite no espaço $q-p$ '.

Tabela 5 Parâmetros do modelo Cam-Clay Modificado.

\begin{tabular}{c|c|c|c|c|c|c}
\cline { 2 - 7 } & $\boldsymbol{N}^{*}$ & $\lambda^{*}$ & $\boldsymbol{\kappa}^{*}$ & $\boldsymbol{G}(\mathbf{k P a})$ & $\boldsymbol{M}$ & $\boldsymbol{O C R}^{*}$ \\
\hline $\mathbf{A P 1}$ & 3,49 & 0,22 & 0,010 & 6700 & 1,73 & 1,87 \\
\hline $\mathbf{A P 2}$ & 3,22 & 0,16 & 0,0092 & 6700 & 1,51 & 1,44 \\
\hline $\mathbf{A V}$ & 2,14 & 0,018 & 0,0009 & 54200 & 1,42 & 3,46 \\
\hline
\end{tabular}



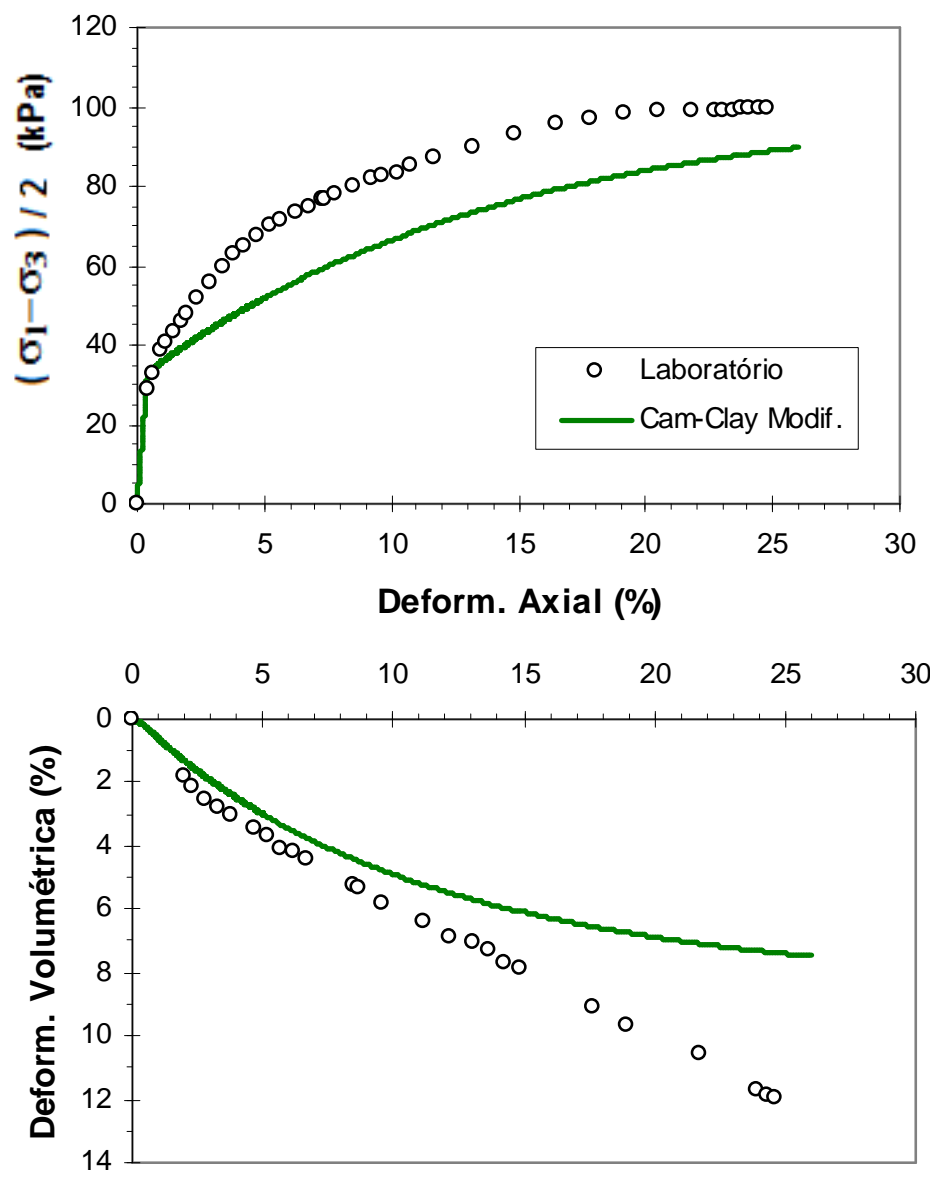

Figura 42 Reprodução numérica do ensaio triaxial drenado de compressão por carregamento - AP1 $\left(\sigma_{3}=49 \mathrm{kPa}\right)-$ Cam-Clay Modificado.

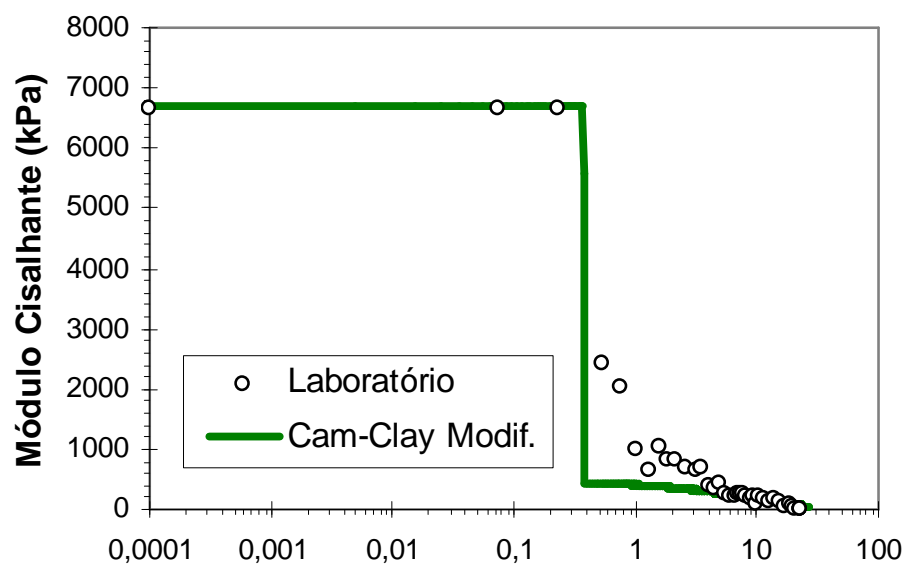

Deform. Axial (\%)

Figura 43 Variação do módulo de rigidez cisalhante conseguida com a reprodução numérica do ensaio triaxial acima - AP1 - Cam-Clay Modificado. 
Tensão Vertical (kPa)

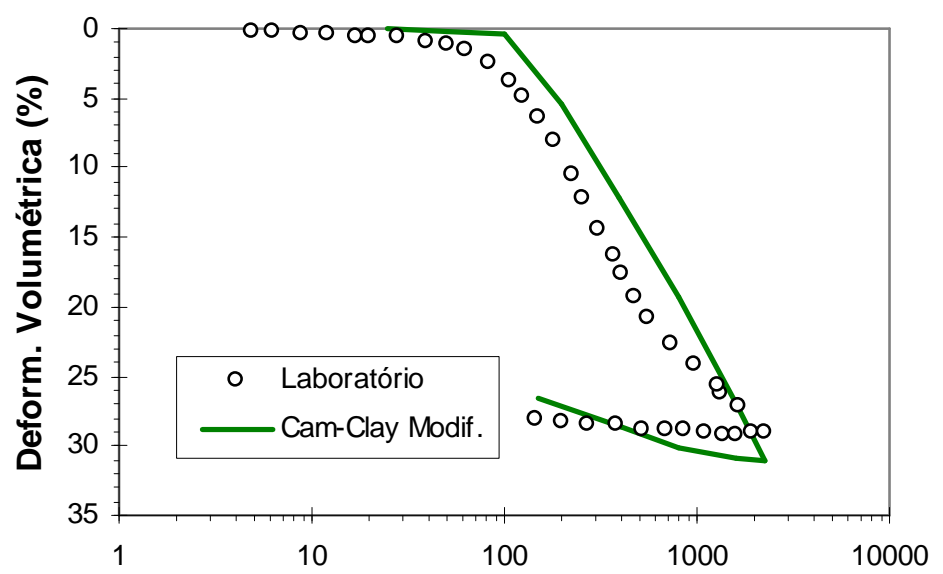

Figura 44 Reprodução numérica do ensaio edométrico - AP1 - Cam-Clay Modificado. 

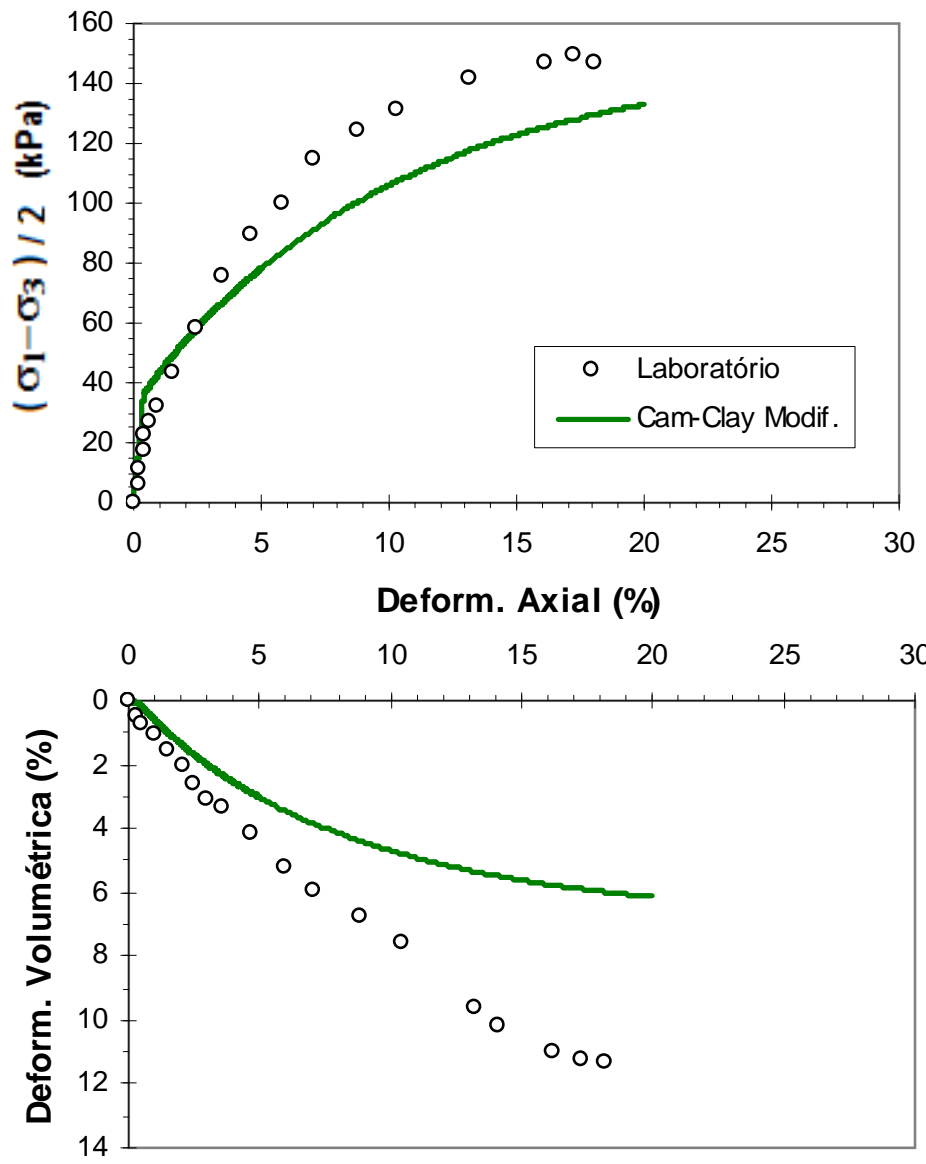

Figura 45 Reprodução numérica do ensaio triaxial drenado de compressão por carregamento - AP2 $\left(\sigma_{3}=98,1 \mathrm{kPa}\right)-$ Cam-Clay Modificado.

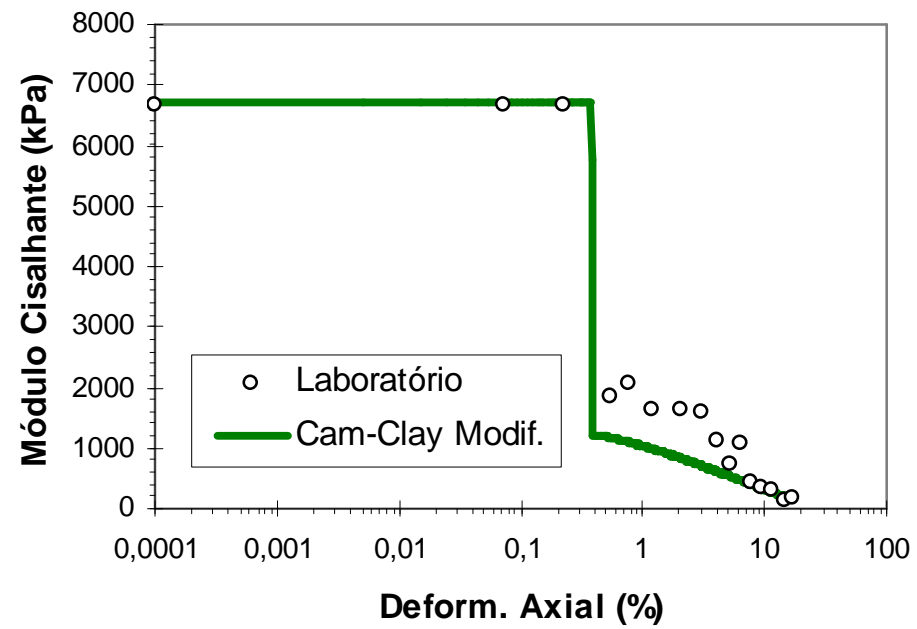

Figura 46 Variação do módulo de rigidez cisalhante conseguida com a reprodução numérica do ensaio triaxial acima - AP2 - Cam-Clay Modificado. 
Tensão Vertical (kPa)

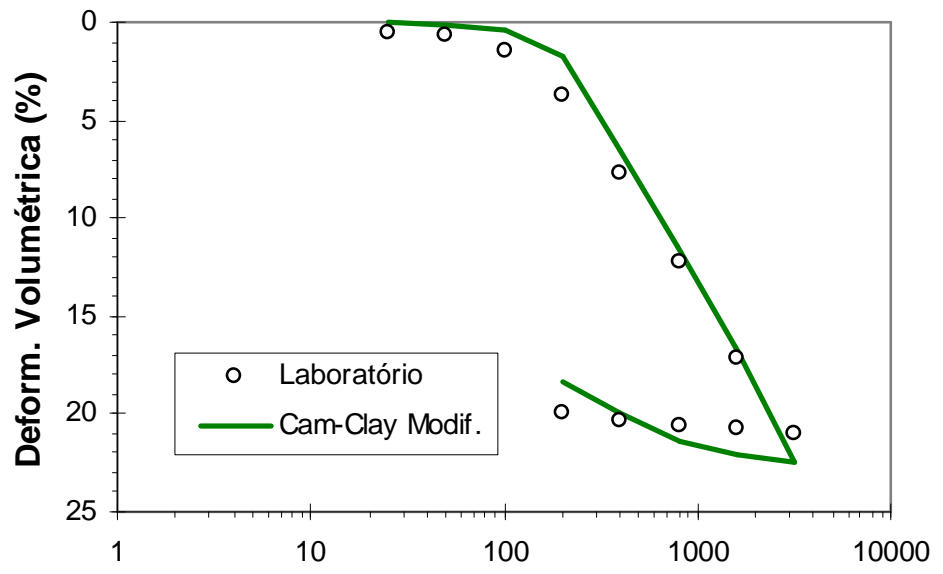

Figura 47 Reprodução numérica do ensaio edométrico - AP2 - Cam-Clay Modificado. 

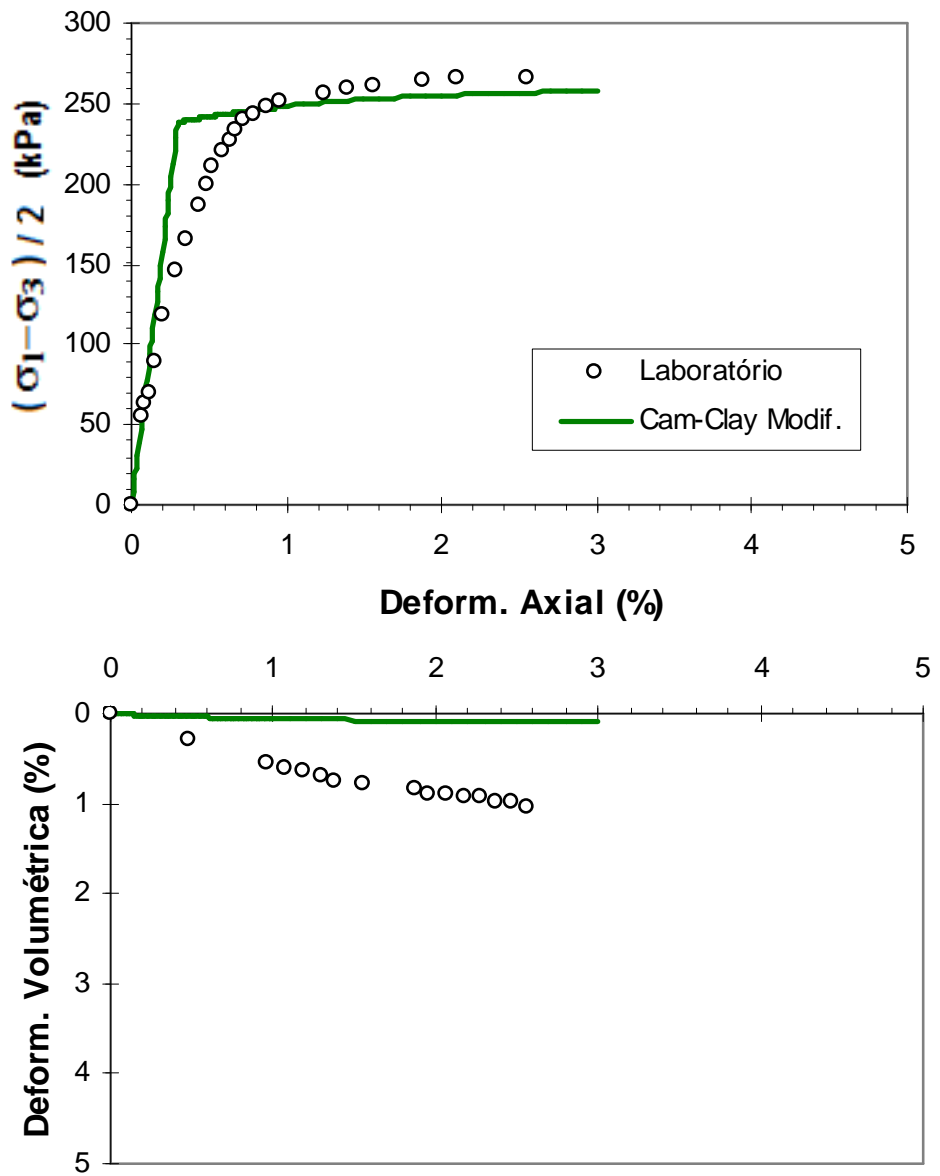

Figura 48 Reprodução numérica do ensaio triaxial drenado de compressão por carregamento - AV $\left(\sigma_{3}=196,1 \mathrm{kPa}\right)$ - Cam-Clay Modificado.

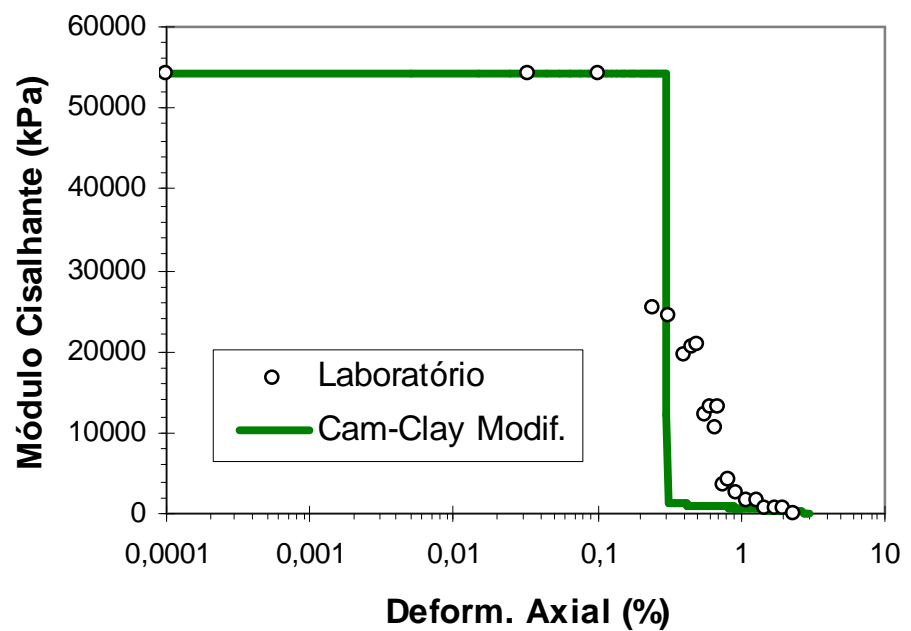

Figura 49 Variação do módulo de rigidez cisalhante conseguida com a reprodução numérica do ensaio triaxial acima - AV - Cam-Clay Modificado. 
Tensão Vertical (kPa)

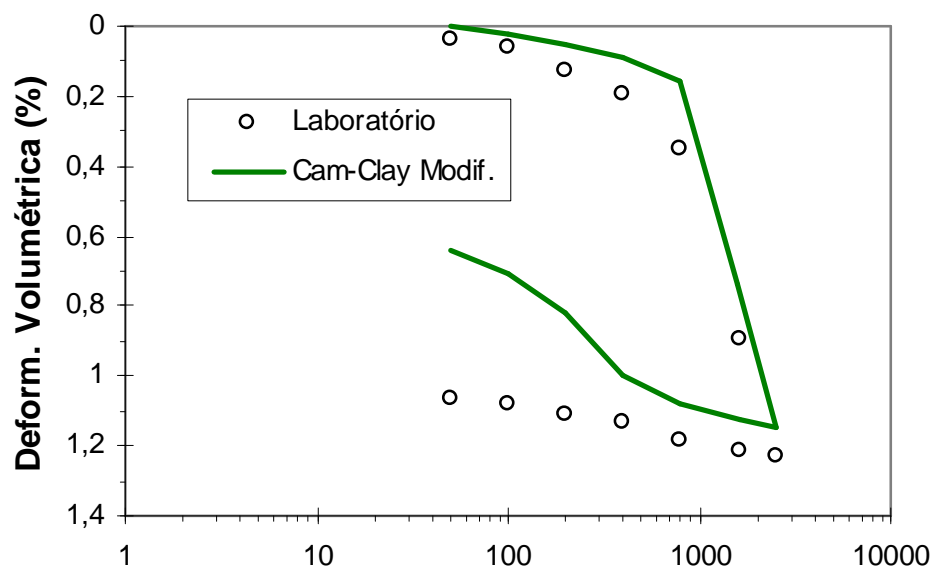

Figura 50 Reprodução numérica do ensaio edométrico - AV - Cam-Clay Modificado.

Chama a atenção a baixíssima deformação volumétrica prevista pelo Cam-Clay Modificado para a Argila Variegada. Este fato é conseqüência do baixo valor do parâmetro $\kappa$ deste material, que conduz a uma elevada rigidez volumétrica elástica, $K$, conforme demonstra a equação reapresentada abaixo:

$$
K=\frac{v p^{\prime}}{\kappa}
$$

O modelo Cinemático com Duas Superfícies Modificado do Imperial College possui os valores dos parâmetros $N^{*}, \lambda^{*}, \kappa^{*}, M$ e $G$ idênticos aos do Cam-Clay Modificado, sendo que, por tentativa e erro, reproduzindo os ensaios triaxiais e edométricos apresentados no capítulo 3, foram obtidos os outros dois parâmetros restantes, $R$ e $\alpha$ (abordados na seção anterior). Todos estes dados de entrada do modelo, incluindo o parâmetro de estado $O C R^{*}$ (mesmos valores utilizados no Cam-Clay Modificado), são apresentados na Tabela 6. O desempenho final do modelo constitutivo na representação dos ensaios dos materiais pode ser observado nas Figuras 51 a 59. 
Tabela 6 Parâmetros do modelo Cinemático com Duas Superfícies Modificado do IC.

\begin{tabular}{c|c|c|c|c|c|c|c|c}
\cline { 2 - 8 } & $\boldsymbol{N}^{*}$ & $\lambda^{*}$ & $\mathbf{K}^{*}$ & $\boldsymbol{G}(\mathbf{k P a})$ & $\boldsymbol{M}$ & $\boldsymbol{R}$ & $\boldsymbol{\alpha}$ & $\boldsymbol{O C} \boldsymbol{R}^{*}$ \\
\hline $\mathbf{A P 1}$ & 3,49 & 0,22 & 0,010 & 6700 & 1,73 & 0,03 & 4 & 1,87 \\
\hline $\mathbf{A P 2}$ & 3,22 & 0,16 & 0,0092 & 6700 & 1,51 & 0,03 & 4 & 1,44 \\
\hline $\mathbf{A V}$ & 2,14 & 0,018 & 0,0009 & 54200 & 1,42 & 0,03 & 15 & 3,46 \\
\hline
\end{tabular}
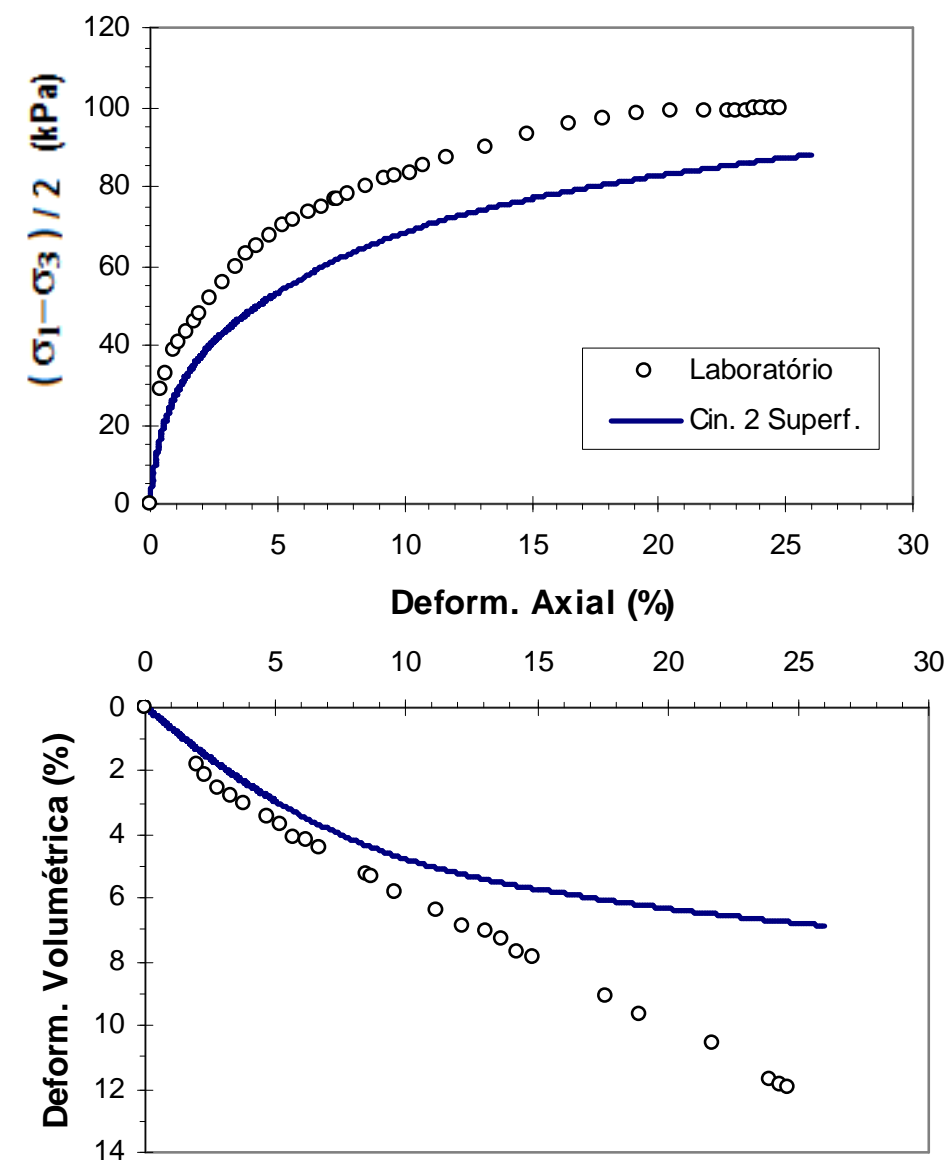

Figura 51 Reprodução numérica do ensaio triaxial drenado de compressão por carregamento - AP1 $\left(\sigma_{3}=49 \mathrm{kPa}\right)$ - Cinemático com Duas Superfícies Modificado do IC. 


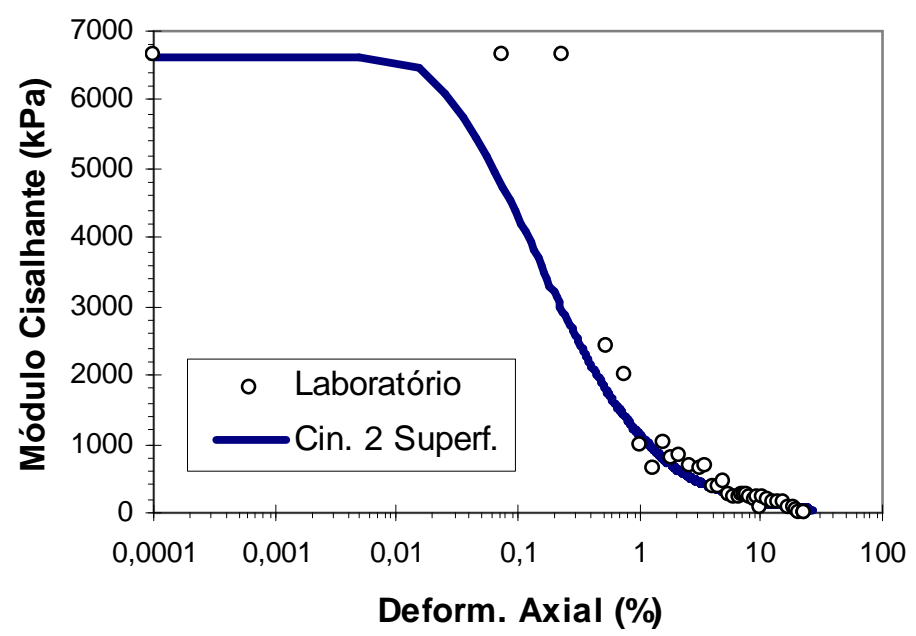

Figura 52 Variação do módulo de rigidez cisalhante conseguida com a reprodução numérica do ensaio triaxial acima - AP1 - Cinemático com Duas Superfícies Modificado do IC.

Tensão Vertical (kPa)

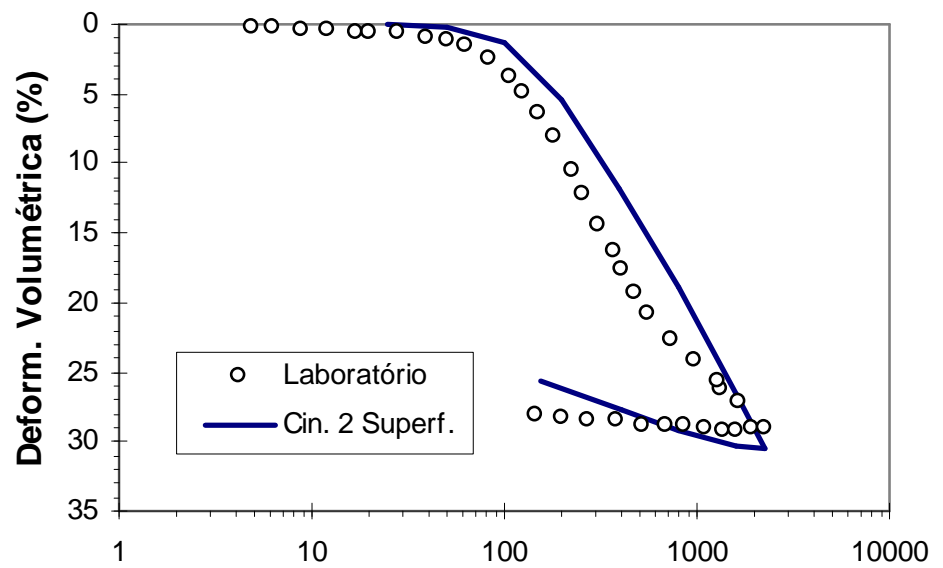

Figura 53 Reprodução numérica do ensaio edométrico - AP1 - Cinemático com Duas Superfícies Modificado do IC. 

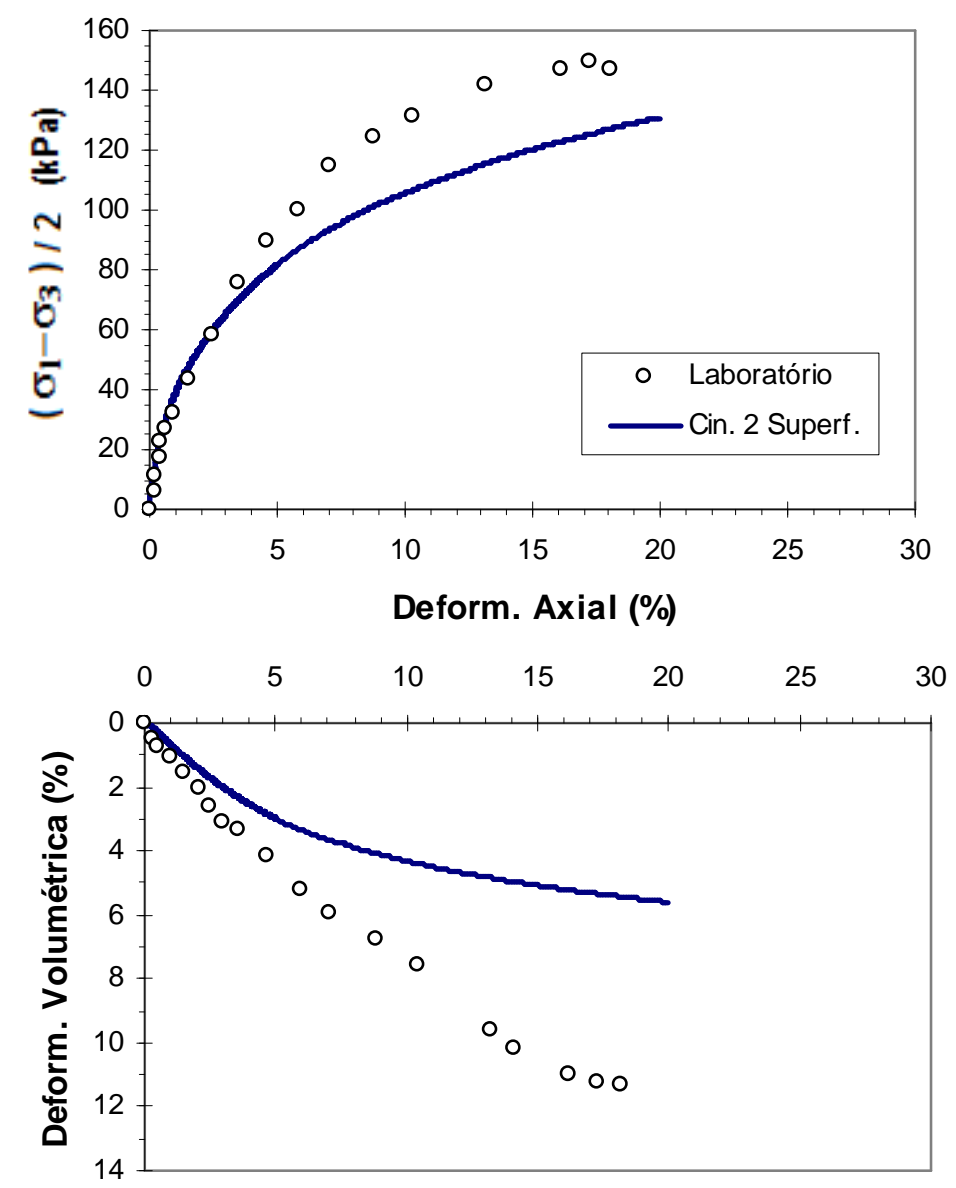

Figura 54 Reprodução numérica do ensaio triaxial drenado de compressão por carregamento $-\mathrm{AP} 2\left(\sigma_{3}=98,1 \mathrm{kPa}\right)$ - Cinemático com Duas Superfícies Modificado do IC.

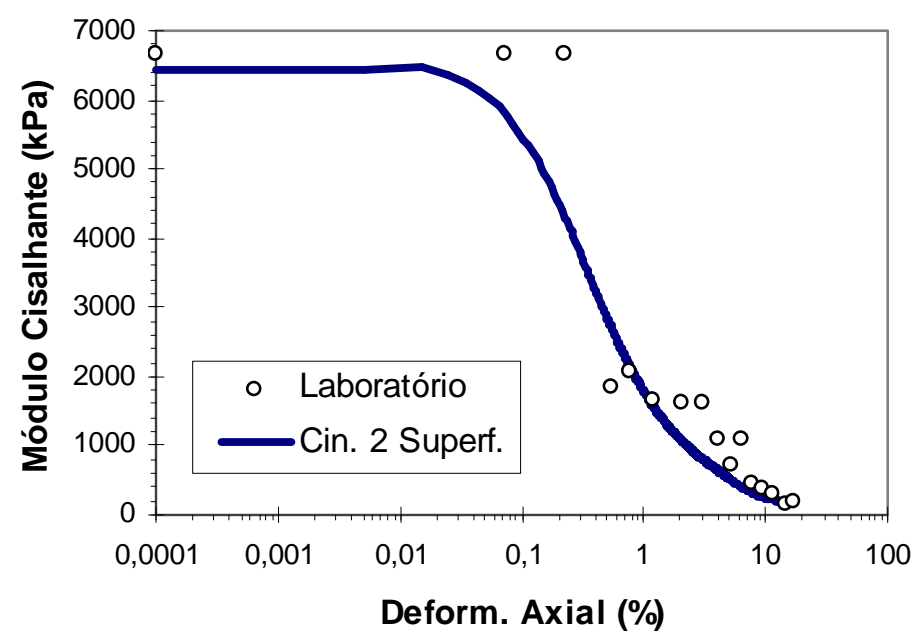

Figura 55 Variação do módulo de rigidez cisalhante conseguida com a reprodução numérica do ensaio triaxial acima - AP2 - Cinemático com Duas Superfícies Modificado do IC. 
Tensão Vertical (kPa)

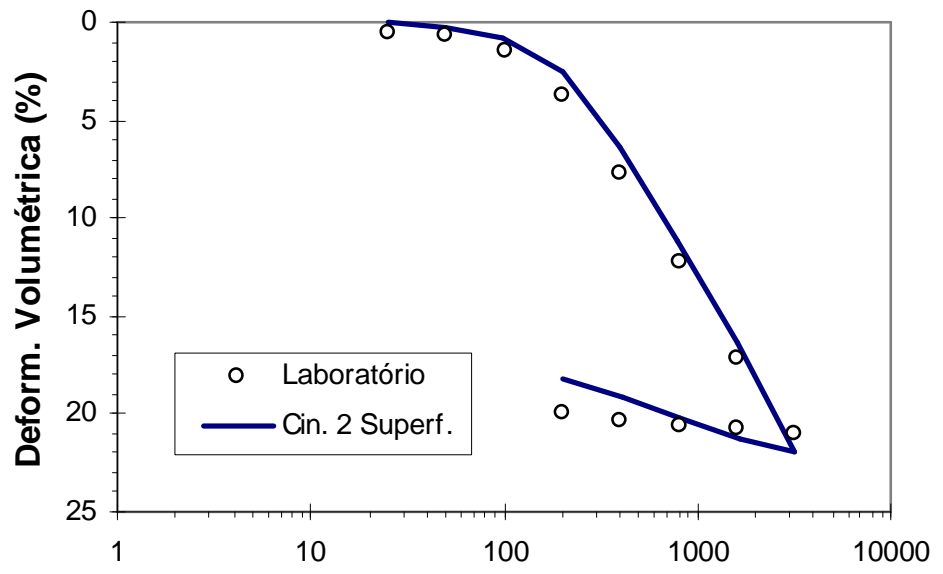

Figura 56 Reprodução numérica do ensaio edométrico - AP2 - Cinemático com Duas Superfícies Modificado do IC. 

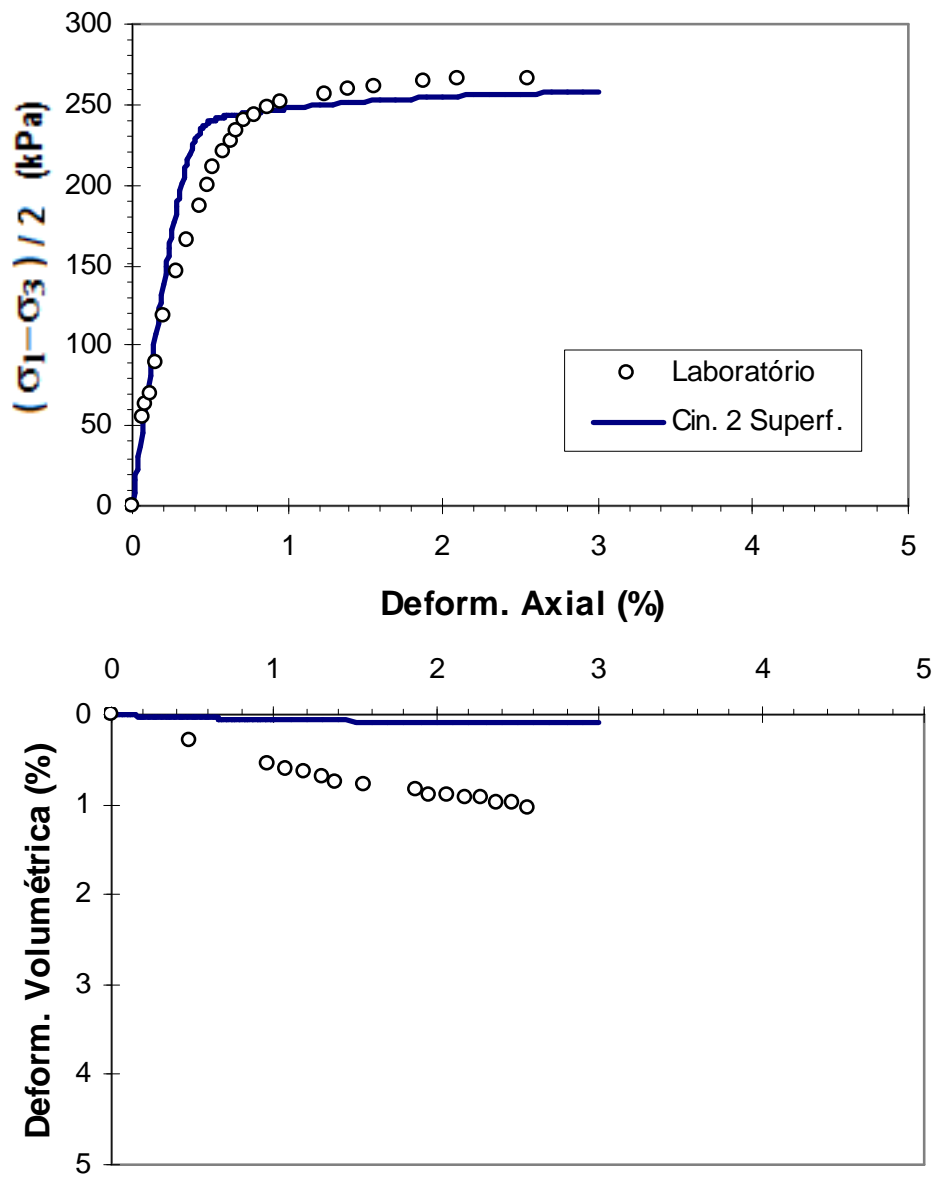

Figura 57 Reprodução numérica do ensaio triaxial drenado de compressão por carregamento - AV $\left(\sigma_{3}=196,1 \mathrm{kPa}\right)$ - Cinemático com Duas Superfícies Modificado do IC.

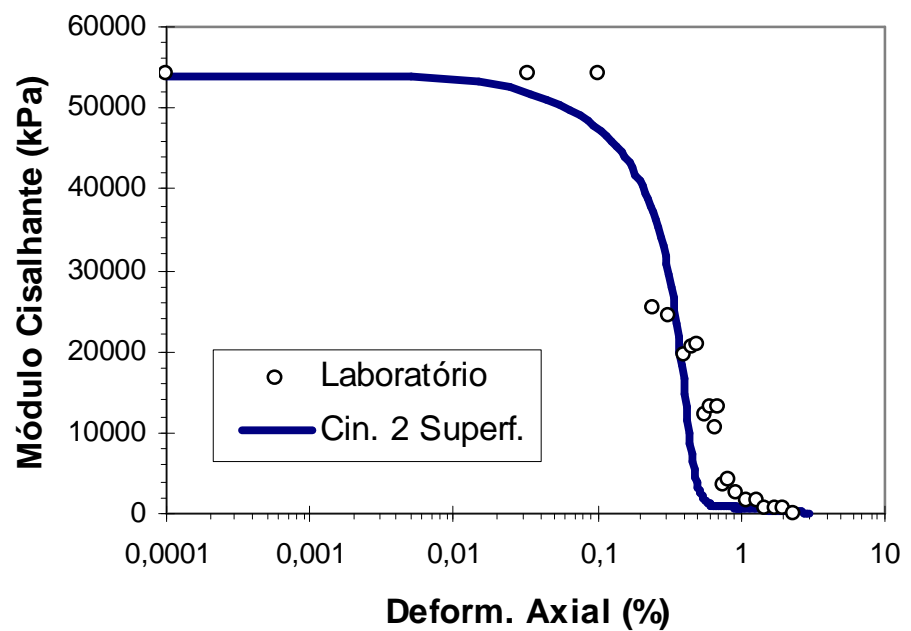

Figura 58 Variação do módulo de rigidez cisalhante conseguida com a reprodução numérica do ensaio triaxial acima - AV - Cinemático com Duas Superfícies Modificado do IC. 
Tensão Vertical (kPa)

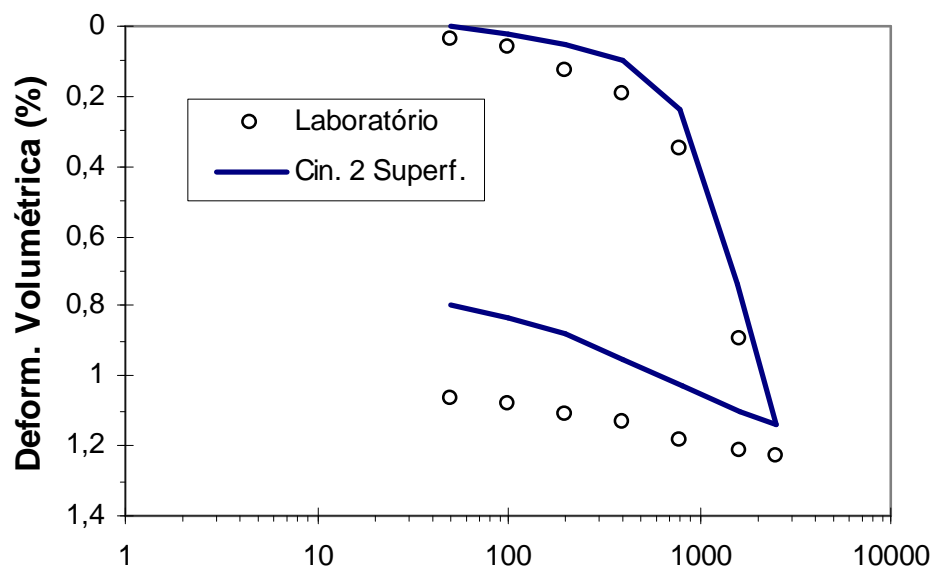

Figura 59 Reprodução numérica do ensaio edométrico - AV - Cinemático com Duas Superfícies Modificado do IC.

O bom desempenho do Cinemático com Duas Superfícies Modificado na reprodução da degradação da rigidez cisalhante, evidenciado nas Figuras 52, 55 e 58, confirma a grande capacidade anunciada deste modelo de representar o comportamento pré-ruptura de materiais sobreadensados, como são as argilas em estudo.

A adequada reprodução dos ensaios edométricos pelo Cinemático com Duas Superfícies, bem como pelo Cam-Clay Modificado, comprova que tais modelos constitutivos são capazes de considerar rigidezes distintas para situações de carregamento e descarregamento. Segundo França (2006), a representação dos peculiares deslocamentos verticais em profundidade observados na cobertura do Túnel Paraíso está justamente associada a análises adotando modelos constitutivos com tais características.

Da mesma maneira como o Cam-Clay Modificado, o Cinemático com Duas Superfícies indicou uma deformação volumétrica baixíssima para a Argila Variegada, consequiência, também, do baixo valor do parâmetro $\kappa$ deste material. Ainda com relação à Argila Variegada, é preciso salientar que se tem ciência que este material sofre solicitações em condições não drenadas durante a escavação, e que a realização de análises em condições drenadas, como são as análises da escavação do Túnel Paraíso desenvolvidas neste trabalho, utilizando parâmetros de um ensaio triaxial drenado deste material, podem levar a uma incorreta representação do comportamento deste estrato. O fato da camada de Argila Variegada envolver apenas a parte inferior do túnel pode, no entanto, reduzir eventuais prejuízos associados a esta não adequada representação do seu comportamento. 


\subsection{MODELOS NUMÉRICOS CONSTRUÍDOS}

O modelo numérico desenvolvido para as análises tridimensionais da escavação do Túnel Paraíso (Figura 60) envolve uma malha de elementos finitos compreendendo 14175 elementos de sólido, munidos com vinte nós, utilizados na representação do meio contínuo, e 2016 elementos de casca, com oito nós, empregados na representação da estrutura de suporte (concreto projetado) e do pavimento existente à superfície. Sua seção transversal foi inicialmente concebida no AutoCAD, procurando concentrar elementos no entorno da abertura, e posteriormente estendida (na direção do eixo z) no ICFEP. As principais características do modelo são enumeradas a seguir:

- escavação simulada através do método passo-a-passo, sob condições drenadas e com reprodução exata da parcialização em calota e bancada realizada em obra (ver Figura 61);

- malha tridimensional representando apenas metade do problema, em razão da simetria, com 50m de largura, $22 \mathrm{~m}$ de altura e $116,8 \mathrm{~m}$ de profundidade. Com tais dimensões foi possível manter a fronteira vertical lateral direita e a fronteira vertical do fundo afastadas de uma distância correspondente a quatro diâmetros respectivamente da borda do túnel e da face do último avanço;

- discretização da malha na longitudinal (direção do eixo z) acompanhando o comprimento do paço de avanço $(1,6 \mathrm{~m})$, até a posição situada a dois diâmetros além do último passo. Desta posição até a fronteira vertical do fundo, aumentou-se gradualmente a dimensão dos elementos na longitudinal;

- estratificação baseada no perfil geotécnico do local (apresentado no capítulo 3): nos primeiros 7m, Argila Porosa 1; de 7 a 12m, Argila Porosa 2; e a partir de 12m, Argila Variegada (até a profundidade igual a $22 \mathrm{~m}$, limite inferior da malha, coincidente com o início de uma formação supostamente indeformável). O nível d'água foi posicionado a $12 \mathrm{~m}$ de profundidade; 
- definição do estado de tensão inicial, considerado geostático, adotando os valores de peso específico natural $(\not)$ dos materiais apresentados na Tabela 1 e os coeficientes de empuxo em repouso $\left(K_{0}\right)$ sugeridos por Parreira (1991): $K_{0}$ igual a 0,58 para as Argilas Porosas 1 e 2, e $K_{0}$ igual a 0,84 para Argila Variegada;

- restrição dos deslocamentos horizontais normais nas fronteiras verticais (laterais, do início e do fundo) e dos deslocamentos em todas as direções na fronteira horizontal inferior;

- emprego de elementos de casca com $20 \mathrm{~cm}$ de espessura (comportamento elástico linear) para representação do concreto projetado, sendo que no momento da aplicação, tanto na calota quanto na bancada (arco invertido), possuíam módulo de rigidez igual a 3GPa, valor alterado para 10GPa após um incremento;

- para representação do pavimento, utilização de elementos de casca com $40 \mathrm{~cm}$ de espessura (valor aproximado da espessura do pavimento da Rua do Paraíso), com comportamento elástico linear e módulo de rigidez igual $1 \mathrm{GPa}$ (somente aos esforços axiais);

O modelo numérico para as análises bidimensionais do Túnel Paraíso representa uma seção transversal do modelo numérico tridimensional (ao invés de elementos de sólido têm-se 225 elementos no plano x-y, munidos com oito nós, e, em substituição às cascas, são introduzidos 32 elementos de barra), sendo a escavação simulada através de redução gradual da tensão in situ no contorno do túnel. 

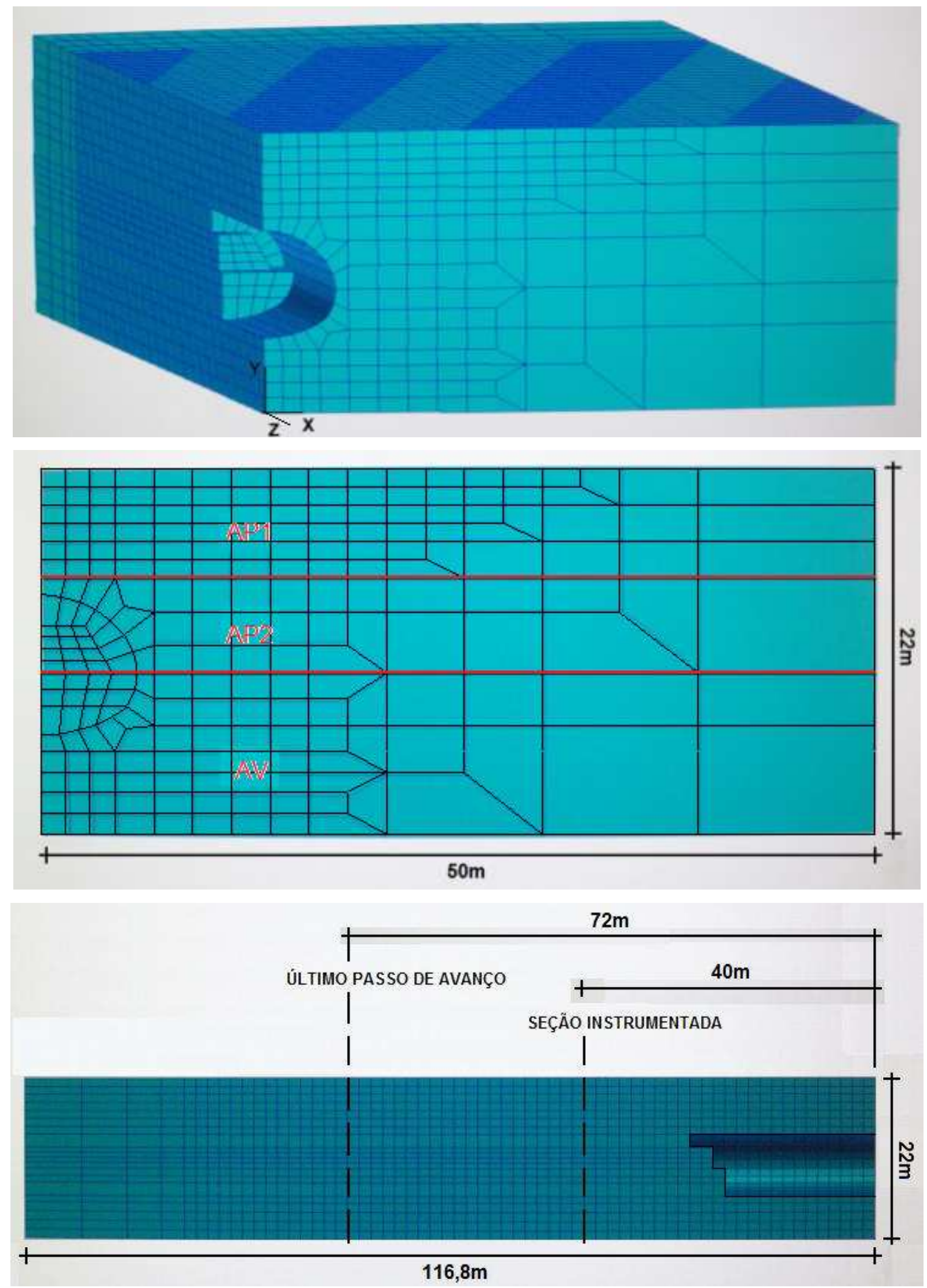

Figura 60 De cima para baixo: malha 3D vista em perspectiva (situação representa um passo de avanço intermediário); seção transversal da malha; seção longitudinal. 


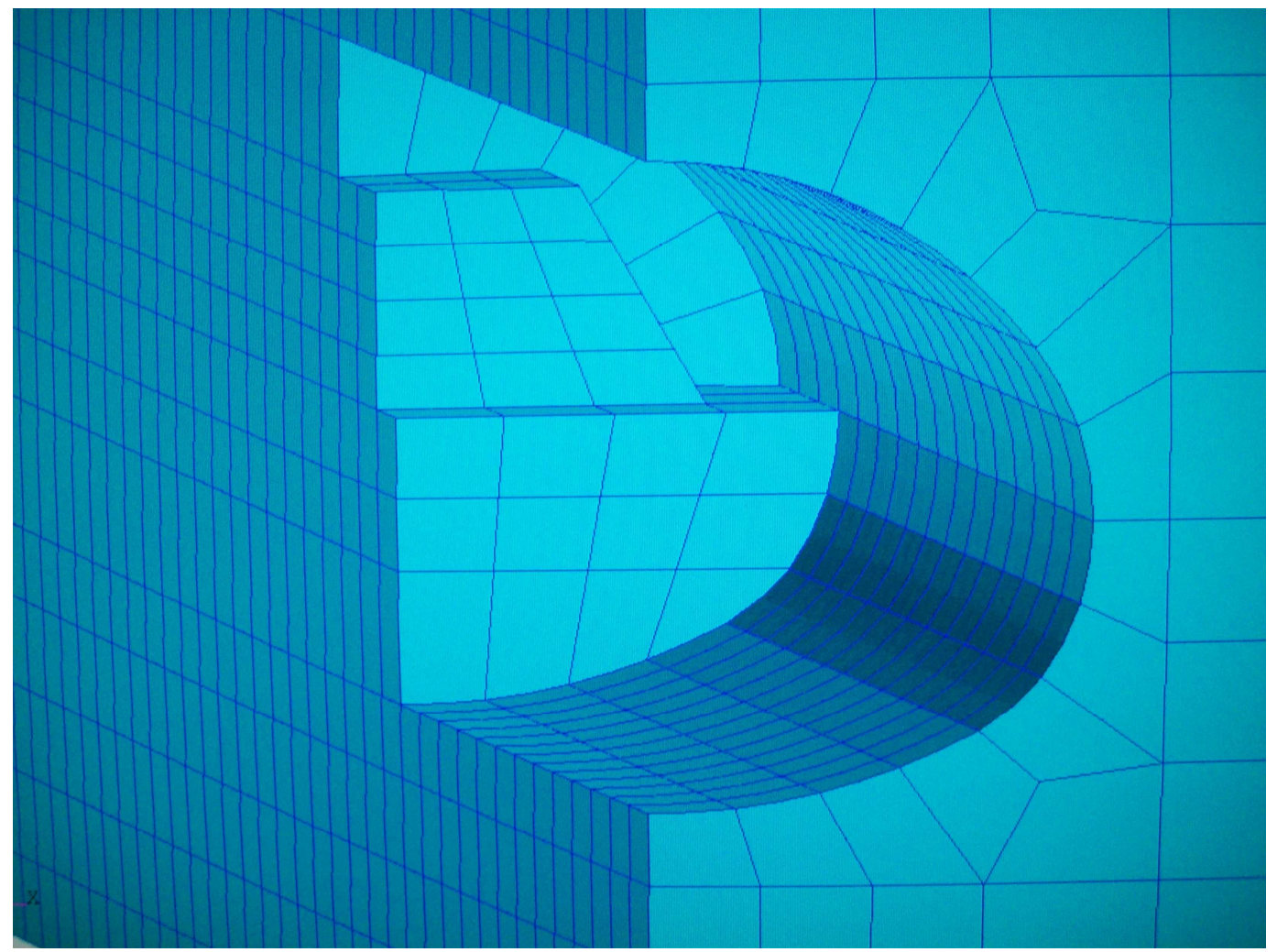

Figura 61 Detalhe da parcialização reproduzida.

\subsection{RESULTADOS}

Esta seção é destinada à apresentação dos resultados conseguidos com as análises bi e tridimensionais da escavação do Túnel Paraíso. A começar pelas análises tridimensionais com o modelo elasto perfeitamente plástico, são apresentadas nas Figuras 62 a 66 as previsões de deslocamentos conseguidas tanto com a adoção de valores de ângulo de dilatância igual a zero (Mohr-Coloumb 1), quanto com a experiência de adoção de valores de ângulo de dilatância negativos (Mohr-Coloumb 2). 
Distância do eixo do túnel (m)

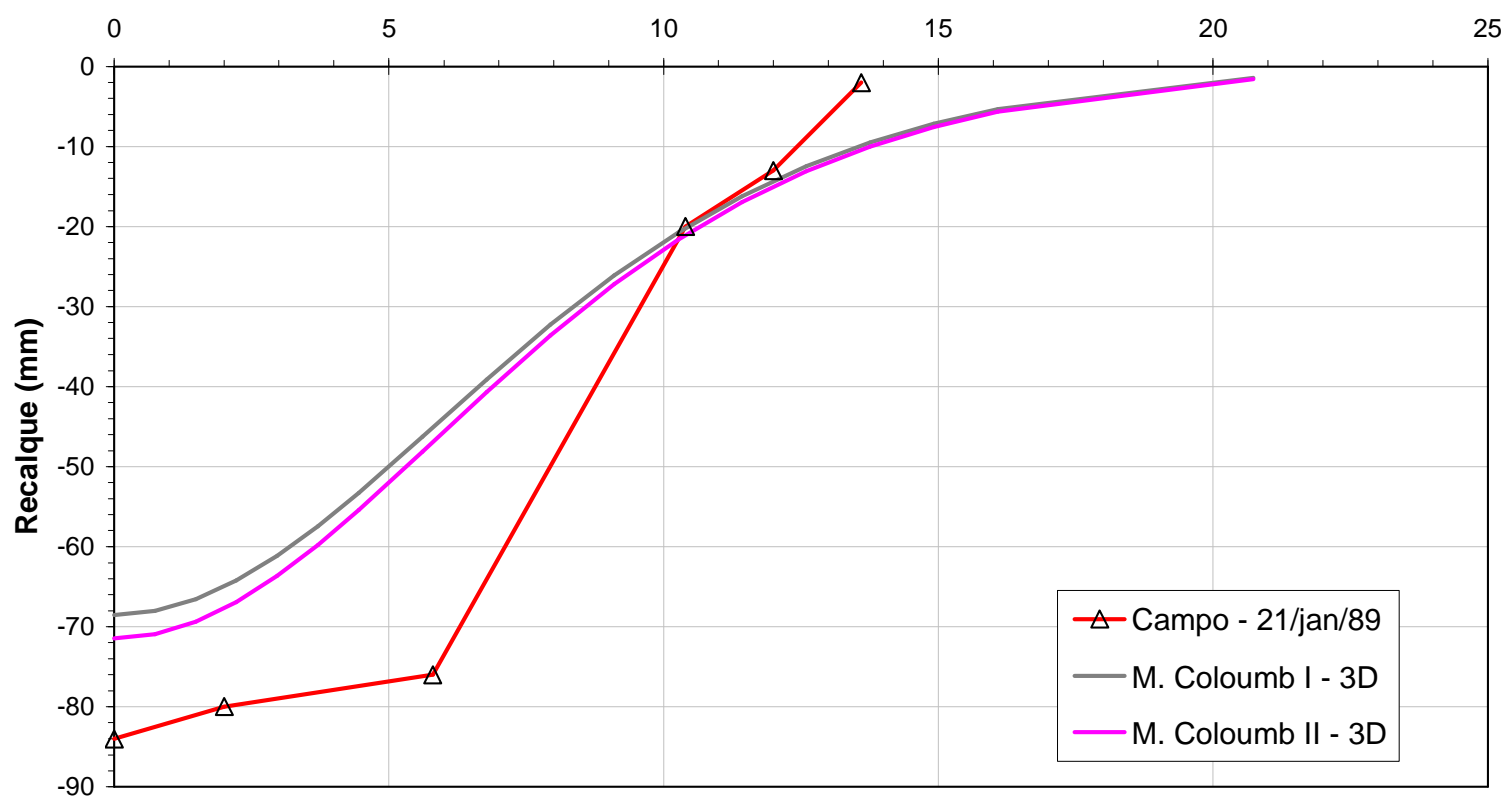

Figura 62 Bacias de recalques superficiais - análises numéricas 3D x campo.

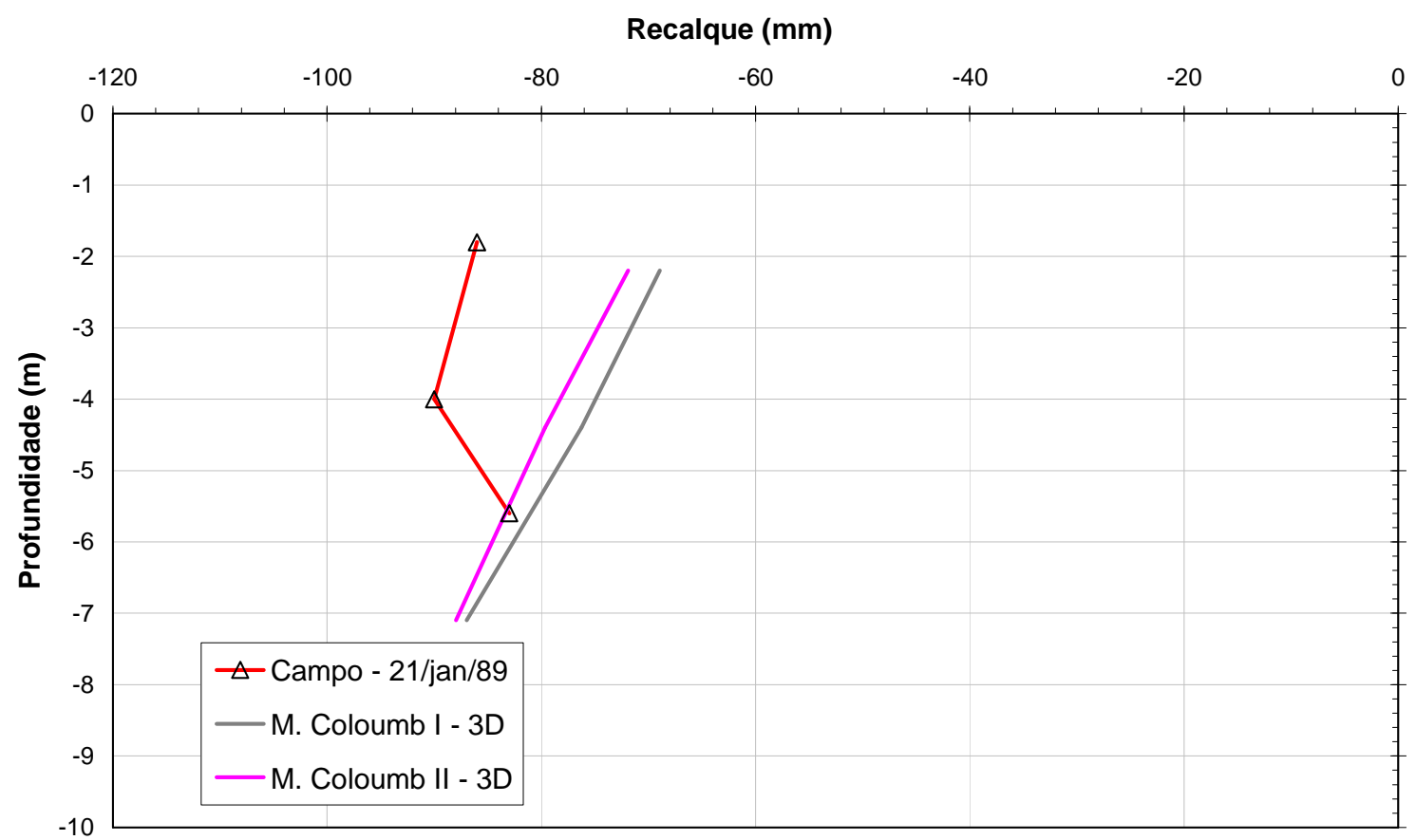

Figura 63 Recalques em profundidade - extensômetros magnéticos a 1m do eixo do túnel análises numéricas 3D x campo. 
Recalque (mm)

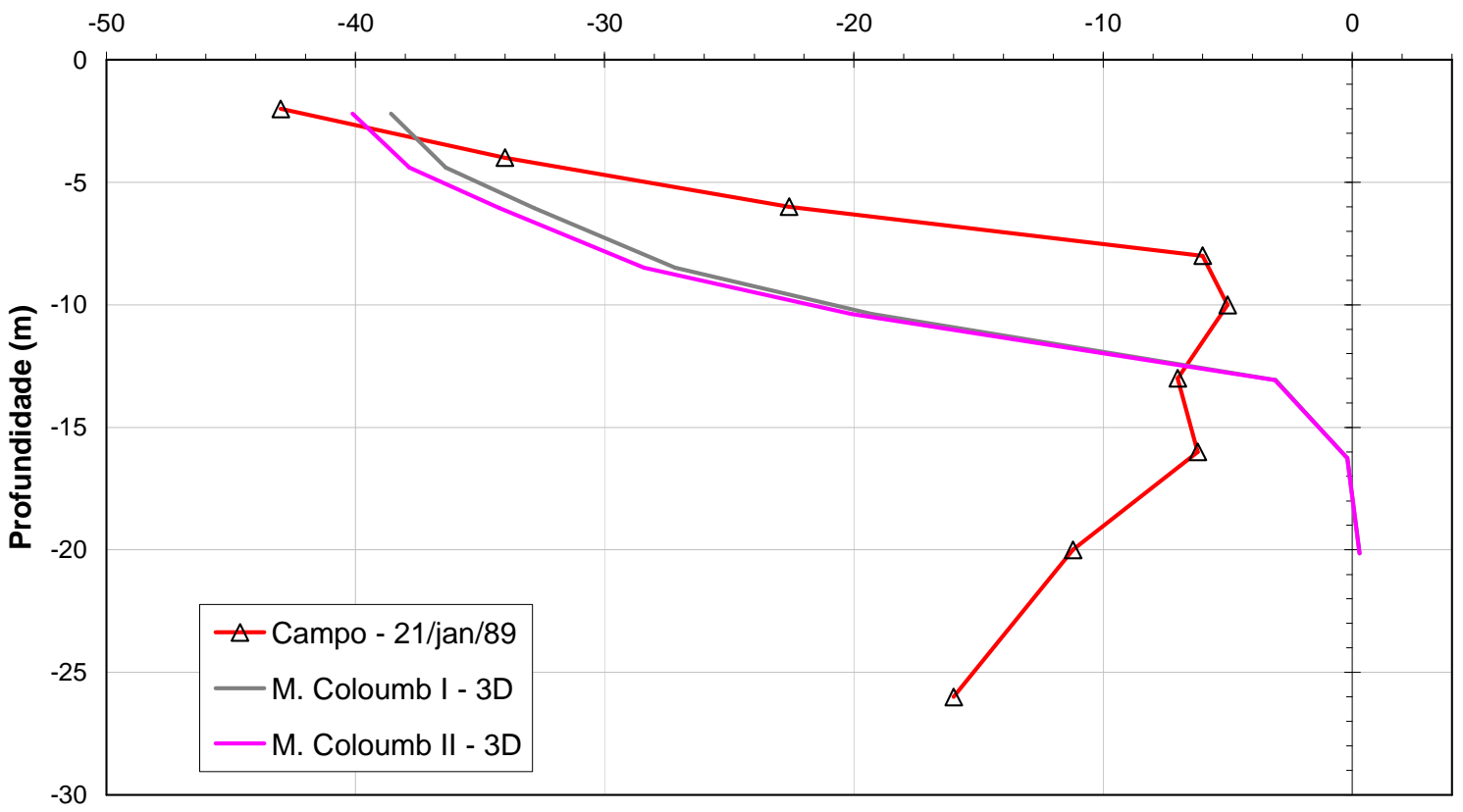

Figura 64 Recalques em profundidade - extensômetros magnéticos a $6 \mathrm{~m}$ do eixo do túnel análises numéricas 3D x campo.

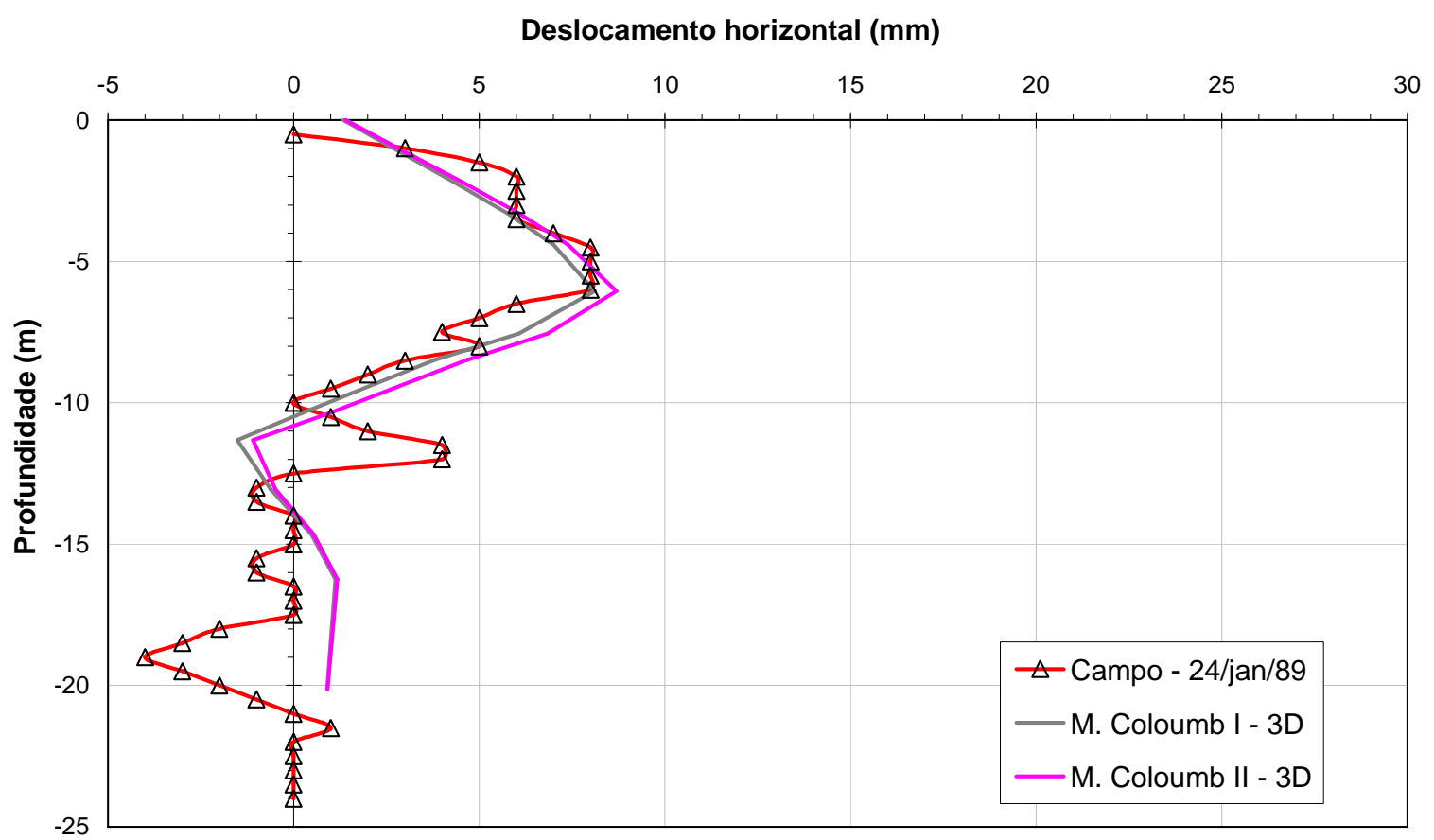

Figura 65 Deslocamentos horizontais - inclinômetro a $6 \mathrm{~m}$ do eixo do túnel - análises numéricas 3D x campo. 


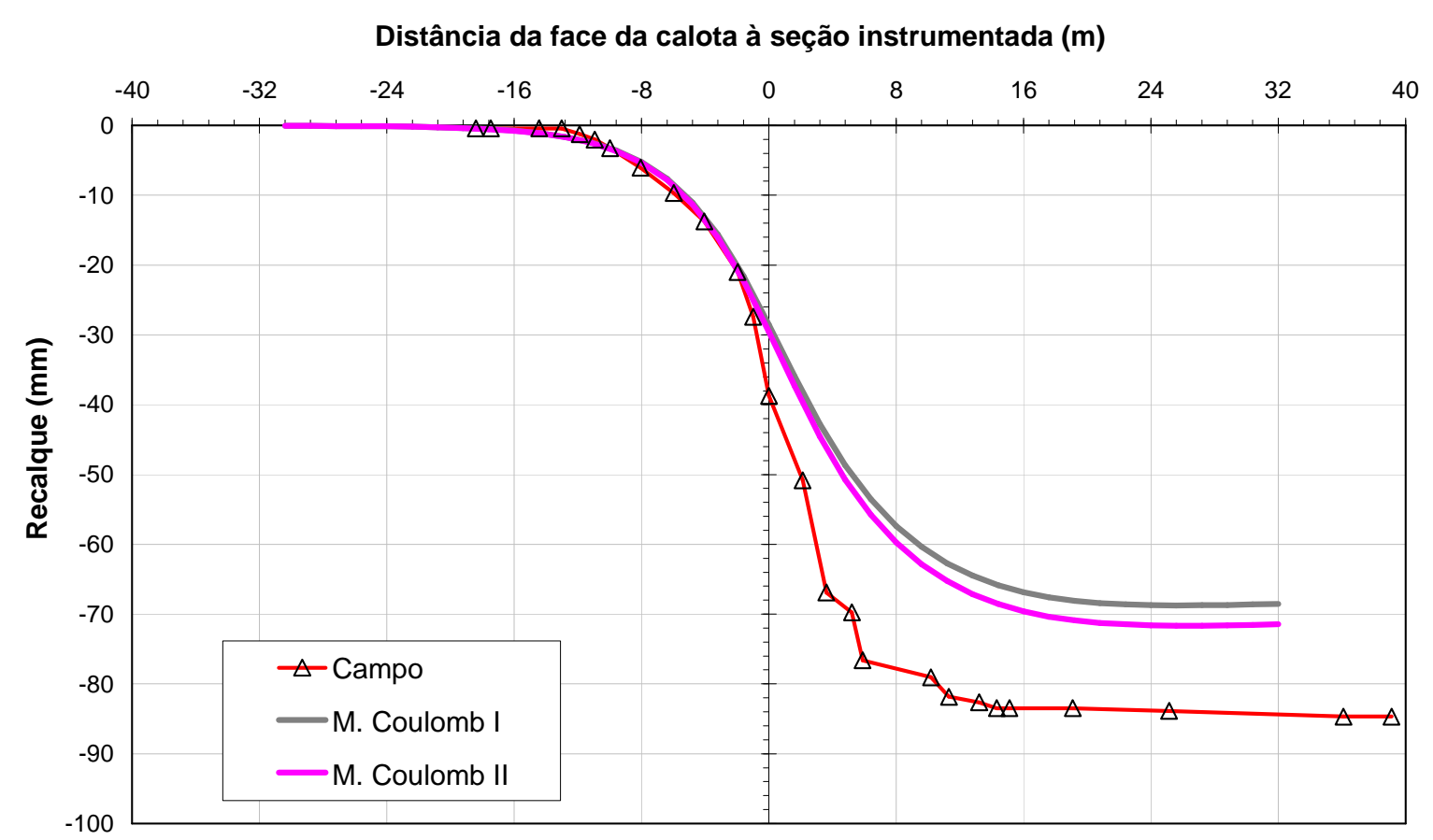

Figura 66 Recalques à superfície conforme avança a escavação - placa de recalque superficial alinhada com o eixo do túnel - análises numéricas 3D x campo.

Os resultados conseguidos com o modelo elasto perfeitamente plástico são em geral de razoável concordância com os dados de instrumentação, com destaque às previsões de deslocamentos horizontais, que podem ser consideradas praticamente coincidentes com as informações de campo até a profundidade igual a 10m (Figura 65). A experiência da adoção de valores de ângulo de dilatância negativos (análise Mohr-Coloumb 2), que melhor representou as deformações volumétricas dos materiais durante a etapa de reprodução de ensaios, mostrou-se positiva também para análise da escavação do túnel, uma vez que os deslocamentos conseguidos com ela foram um pouco maiores e mais próximos dos observados que os obtidos com a adoção de ângulos de dilatância igual a zero (análise MohrColoumb 1). Os deslocamentos verticais em profundidade na cobertura do túnel previstos por este modelo (Figura 63), apesar de próximos aos observados em campo, são de tendência oposta a eles, isto é, crescentes com a profundidade. Uma observação cuidadosa da Figura 66 evidencia que o modelo elasto perfeitamente plástico reproduz muito bem os recalques superficiais no plano da seção instrumentada até a chegada da face da calota à posição -1,6m. A partir do momento que a face da calota está na eminência de atingir a seção instrumentada (posição $0 \mathrm{~m}$ ), as previsões de recalques realizadas pelo modelo imediatamente se restringem, se afastando dos dados de campo, o que parece ser efeito de uma rigidez inicial elevada da 
estrutura de suporte do modelo numérico, já que é neste momento, com aproximação e passagem da frente pela seção instrumentada, que a influência desta estrutura tende a se manifestar. Talvez o valor de $3 \mathrm{GPa}$ adotado para a rigidez inicial do concreto projetado seja ainda elevado (como sugere Sousa (1998), que utiliza 0,6GPa) e tenha inibido os deslocamentos verticais na seção instrumentada do modelo numérico quando da passagem da frente de escavação pelo trecho situado entre as posições -1,6m e 4,8m (esta última associada ao momento do fechamento da estrutura de suporte no plano da seção instrumentada), gerando uma defasagem entre estes deslocamentos e os valores observados em campo que praticamente se mantém até o final da escavação.

As previsões de deslocamentos conseguidas com a análise tridimensional adotando o modelo Cam-Clay Modificado são apresentadas nas Figuras 67 a 71. 
Distância do eixo do túnel (m)

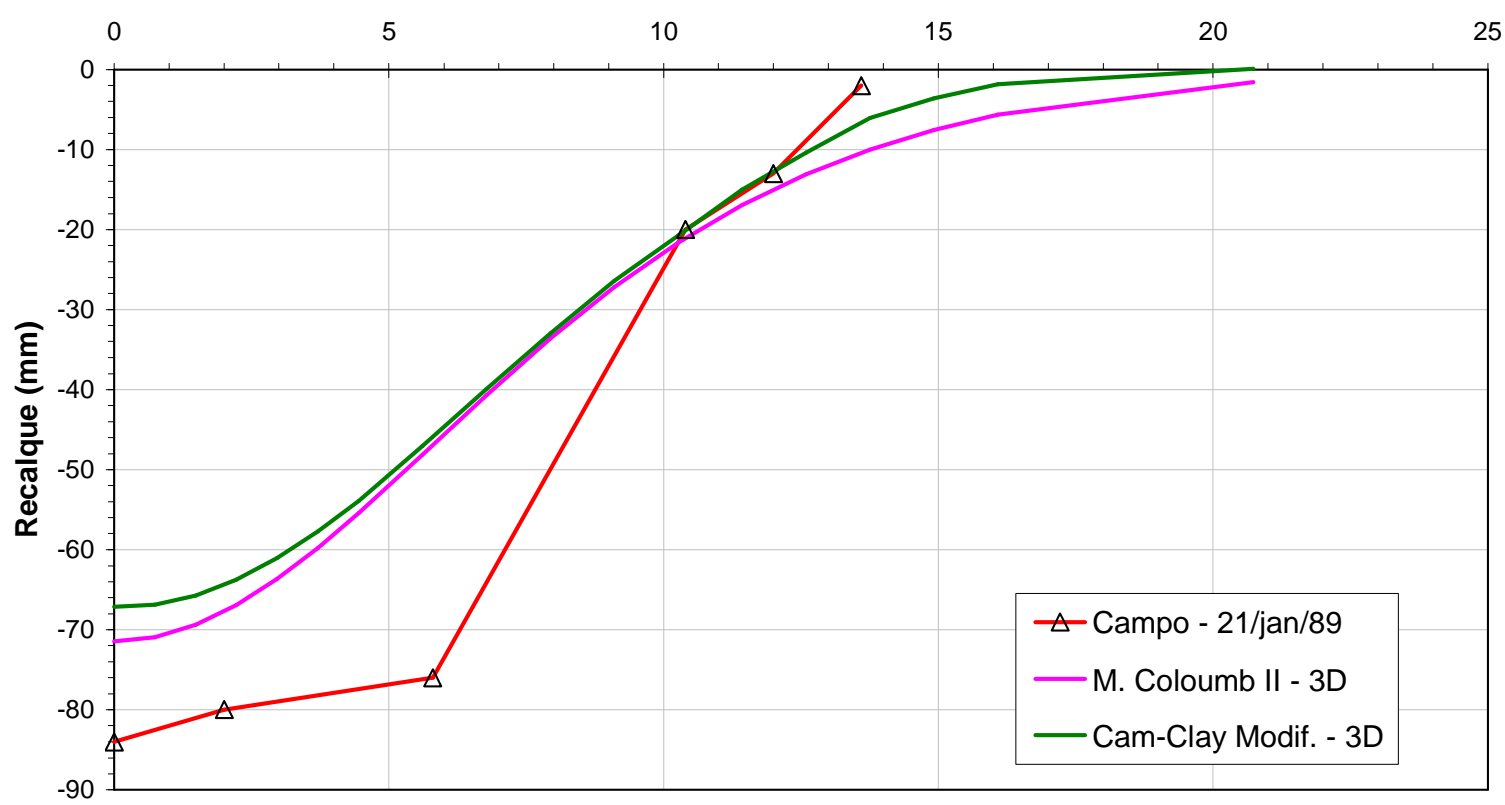

Figura 67 Bacias de recalques superficiais - análises numéricas 3D x campo.

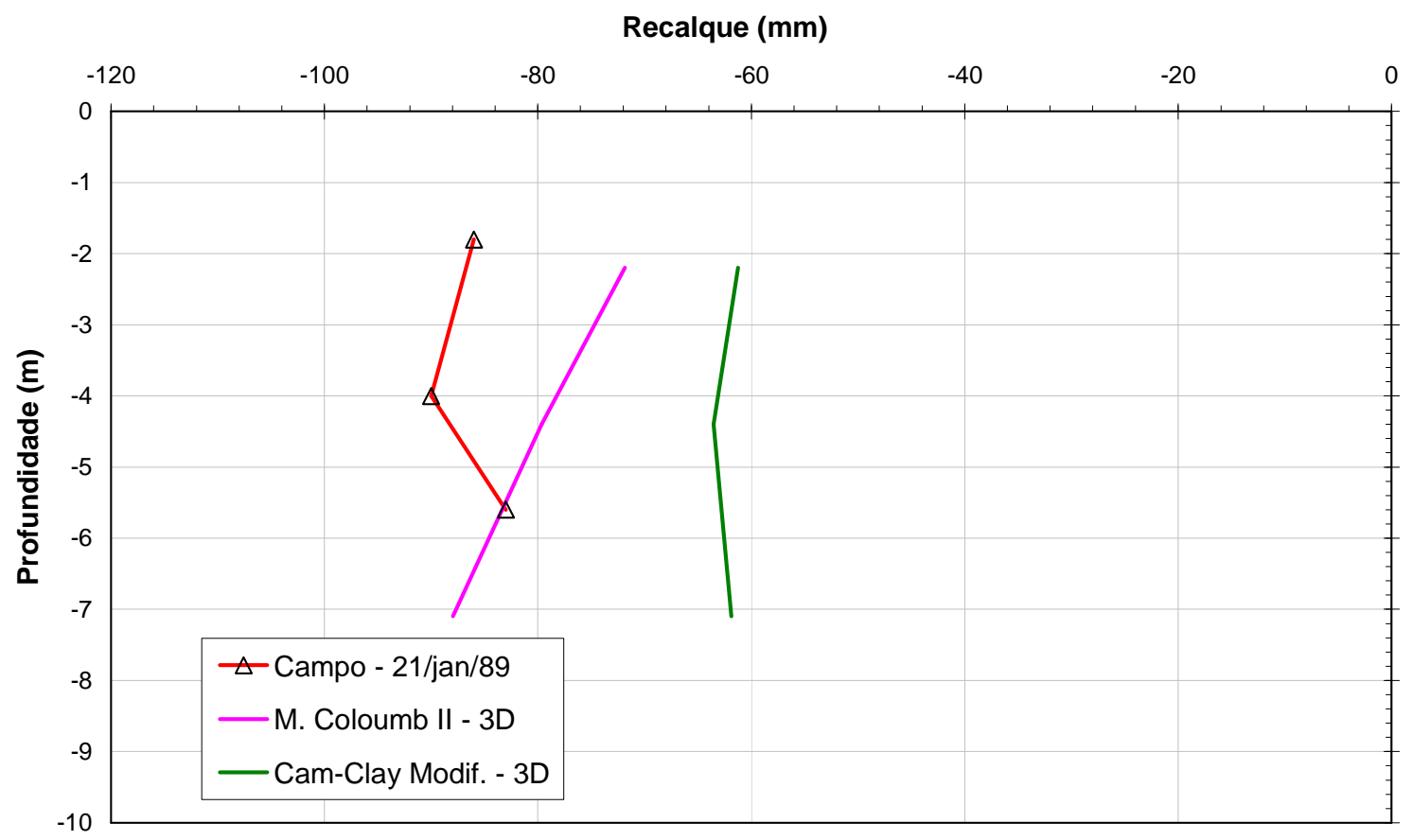

Figura 68 Recalques em profundidade - extensômetros magnéticos a 1m do eixo do túnel análises numéricas 3D x campo. 


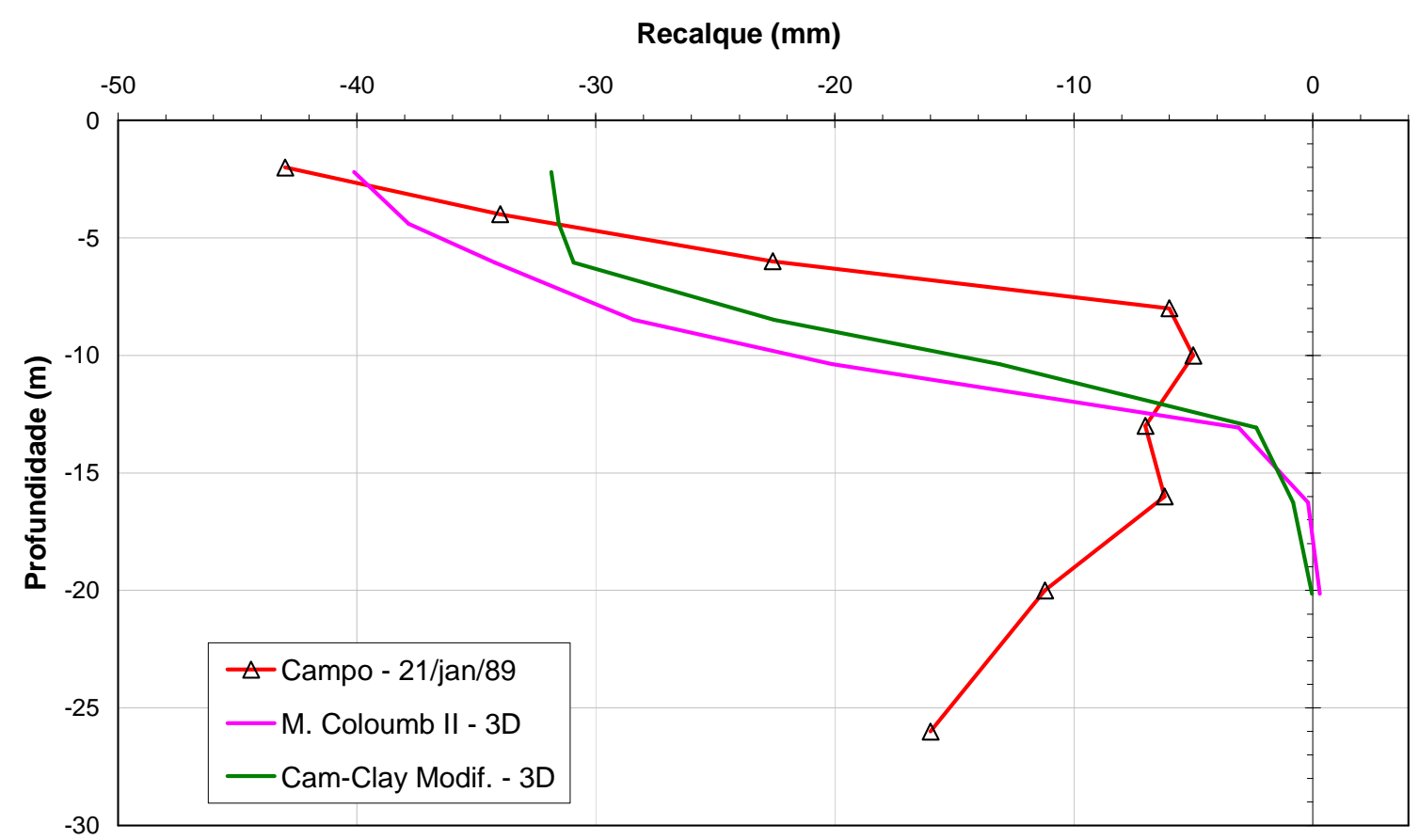

Figura 69 Recalques em profundidade - extensômetros magnéticos a $6 \mathrm{~m}$ do eixo do túnel análises numéricas 3D x campo.

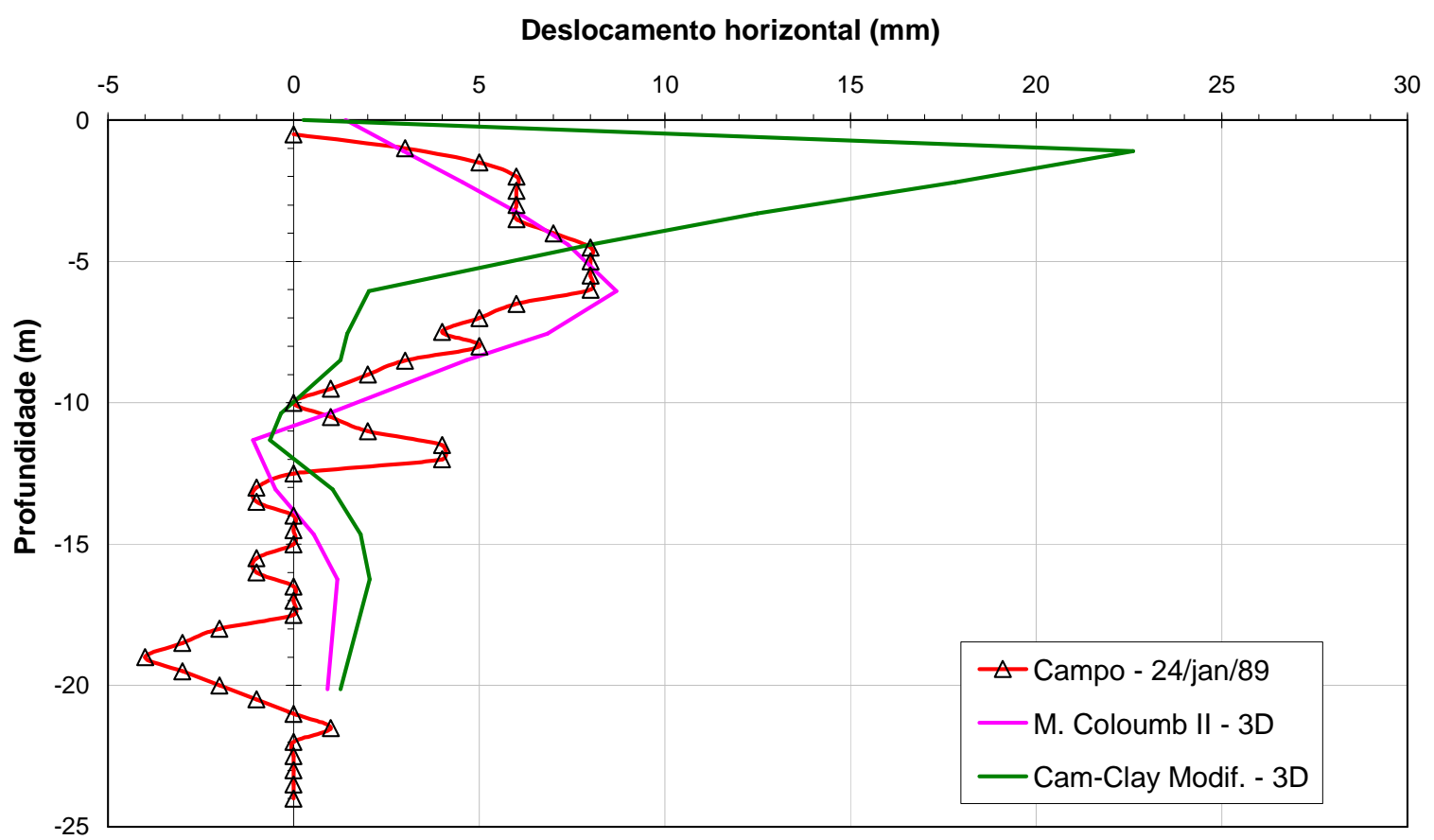

Figura 70 Deslocamentos horizontais - inclinômetro a $6 \mathrm{~m}$ do eixo do túnel - análises numéricas 3D x campo. 


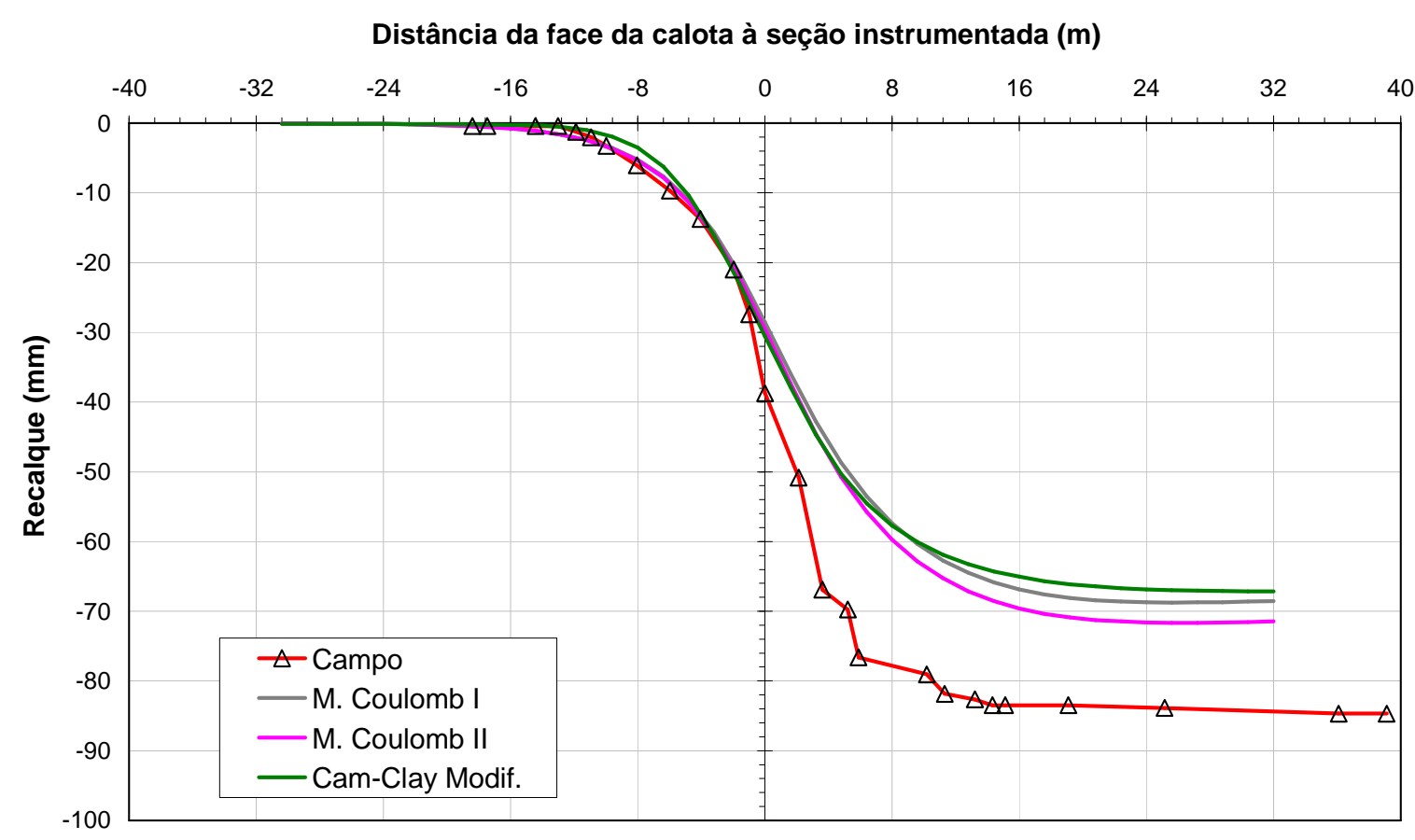

Figura 71 Recalques à superfície conforme avança a escavação - placa de recalque superficial alinhada com o eixo do túnel - análises numéricas 3D x campo.

Os resultados conseguidos com o Cam-Clay Modificado não são melhores que os das análises com o modelo elasto perfeitamente plástico, com destaque para os deslocamentos horizontais (Figura 70), que destoam bastante dos dados de campo até a profundidade igual a $5 \mathrm{~m}$, comportamento semelhante ao observado nas análises bidimensionais de Silva (2008) adotando este mesmo modelo constitutivo (Figura 2). Os deslocamentos verticais em profundidade na cobertura do túnel (Figura 68), apesar de um pouco afastados dos observados em campo, são, assim como eles, decrescentes com a profundidade a partir de aproximadamente $4 \mathrm{~m}$ abaixo da superfície do terreno. Pode-se afirmar, então, que a análise tridimensional com o Cam-Clay Modificado, modelo capaz de considerar rigidezes distintas para situações de carregamento e descarregamento, conseguiu representar a tendência peculiar dos deslocamentos em profundidade observados na cobertura do Túnel Paraíso. Com relação aos recalques superficiais no plano da seção instrumentada conforme avança a escavação (Figura 71), é possível sustentar a mesma hipótese a respeito do efeito da rigidez inicial elevada da estrutura de suporte do modelo numérico na inibição dos deslocamentos verticais. Uma observação ainda mais cuidadosa da Figura 71 evidencia que os recalques superficiais obtidos pelas três análises realizadas (Mohr-Coloumb 1, Mohr-Coloumb 2 e Cam-Clay 
Modificado) são praticamente coincidentes entre si até a chegada da face da calota à posição 4,8m (momento em que a estrutura de suporte está sendo fechada justamente no plano da seção instrumentada, na posição $0 \mathrm{~m}$ ), sendo que a partir daí, com a estrutura de suporte (fechada) apoiada tubularmente em um berço de Argila Variegada (comprimindo-a), cada perfil de recalque superficial adquire um rumo diferente: o da análise Mohr-Coloumb 2, que proporcionou maiores deformações volumétricas para Argila Variegada durante a reprodução do seu ensaio triaxial, é o mais profundo dos perfis, sendo seguido, nesta ordem, pelo perfil da análise Mohr-Coloumb 1 e pelo perfil da análise com o Cam-Clay Modificado, que é o menos profundo, já que o Cam-Clay Modificado é o modelo que indicou menores deformações volumétricas para a Argila Variegada durante a reprodução do seu ensaio triaxial.

As Figuras 73, 74 e 75 apresentam as tensões registradas respectivamente nos pontos A, B e C da seção instrumentada do modelo numérico (ver Figura 72) com o avanço da escavação.

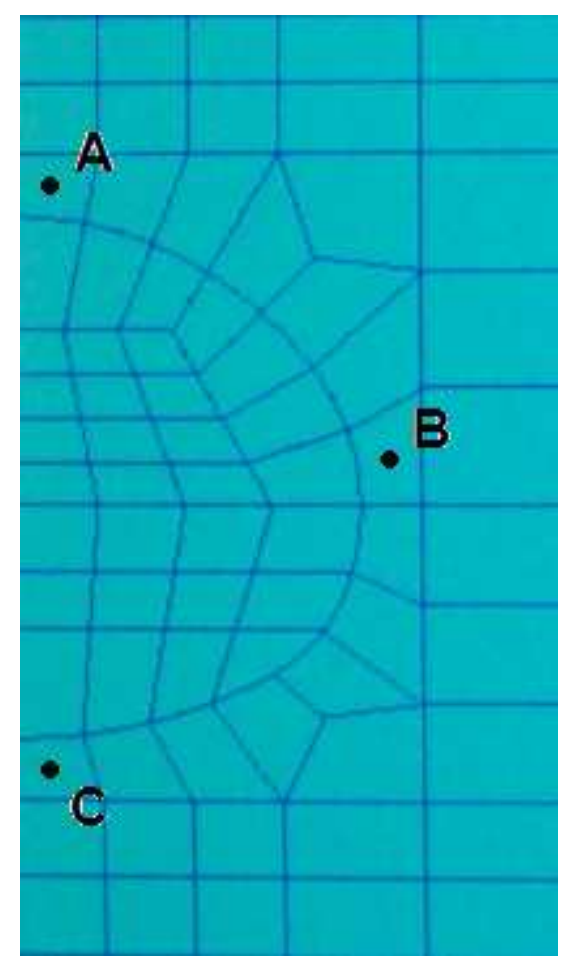

Figura 72 Pontos no plano da seção instrumentada do modelo numérico cujas tensões foram monitoradas. 
Distância da face da calota à seção instrumentada (m)
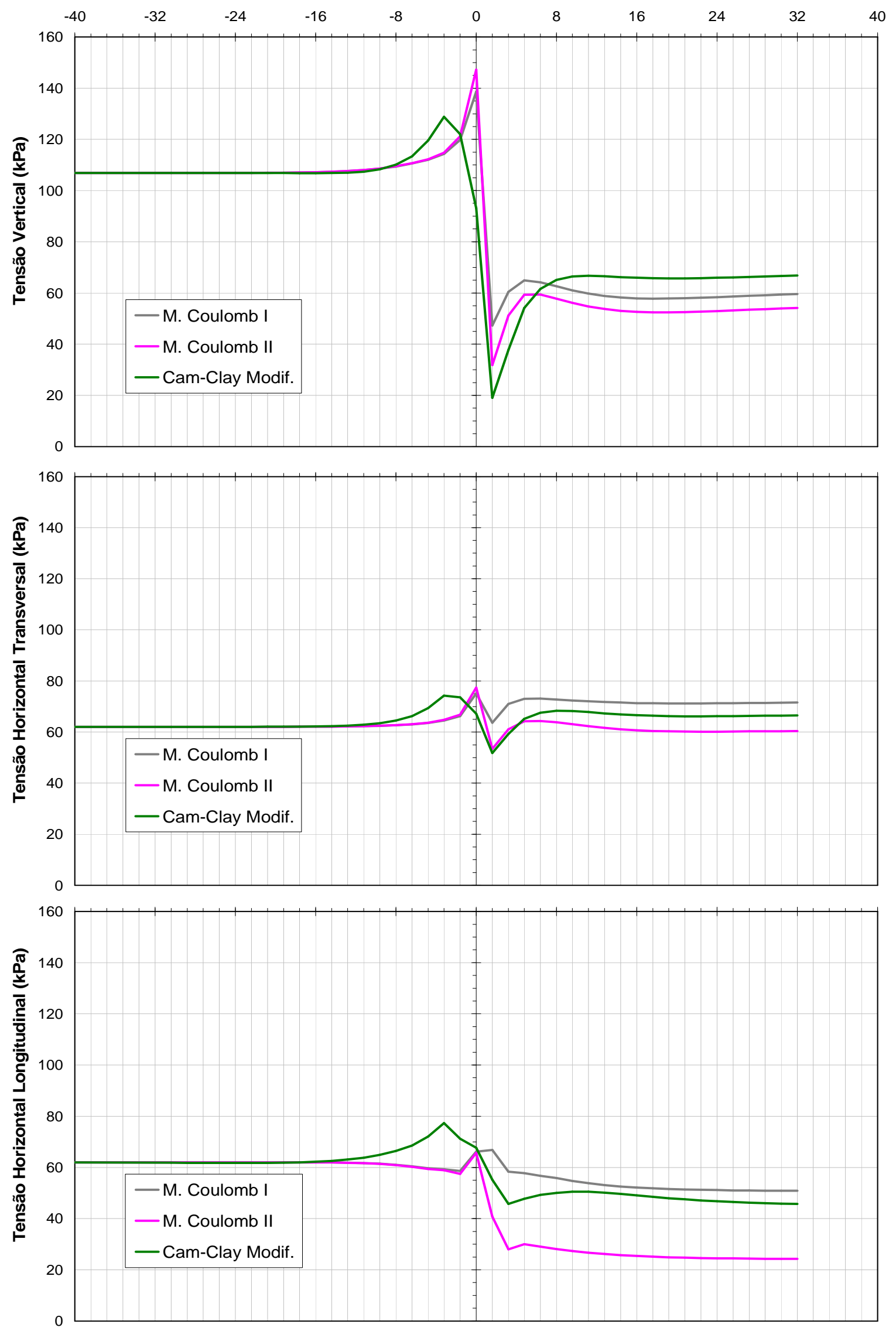

Figura 73 Tensões acima do túnel (ponto A). 

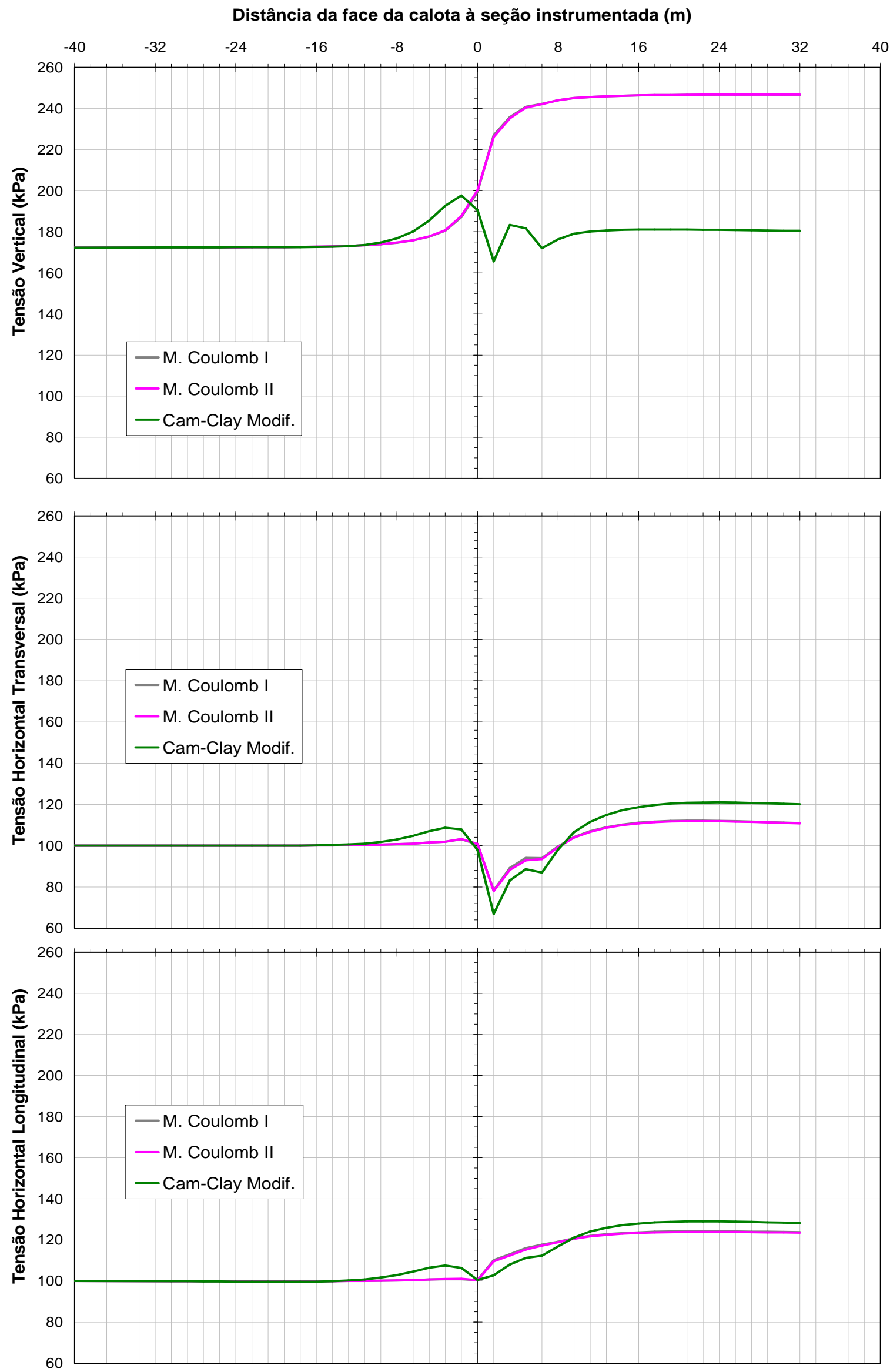

Figura 74 Tensões na lateral do túnel (ponto B). 
Distância da face da calota à seção instrumentada (m)
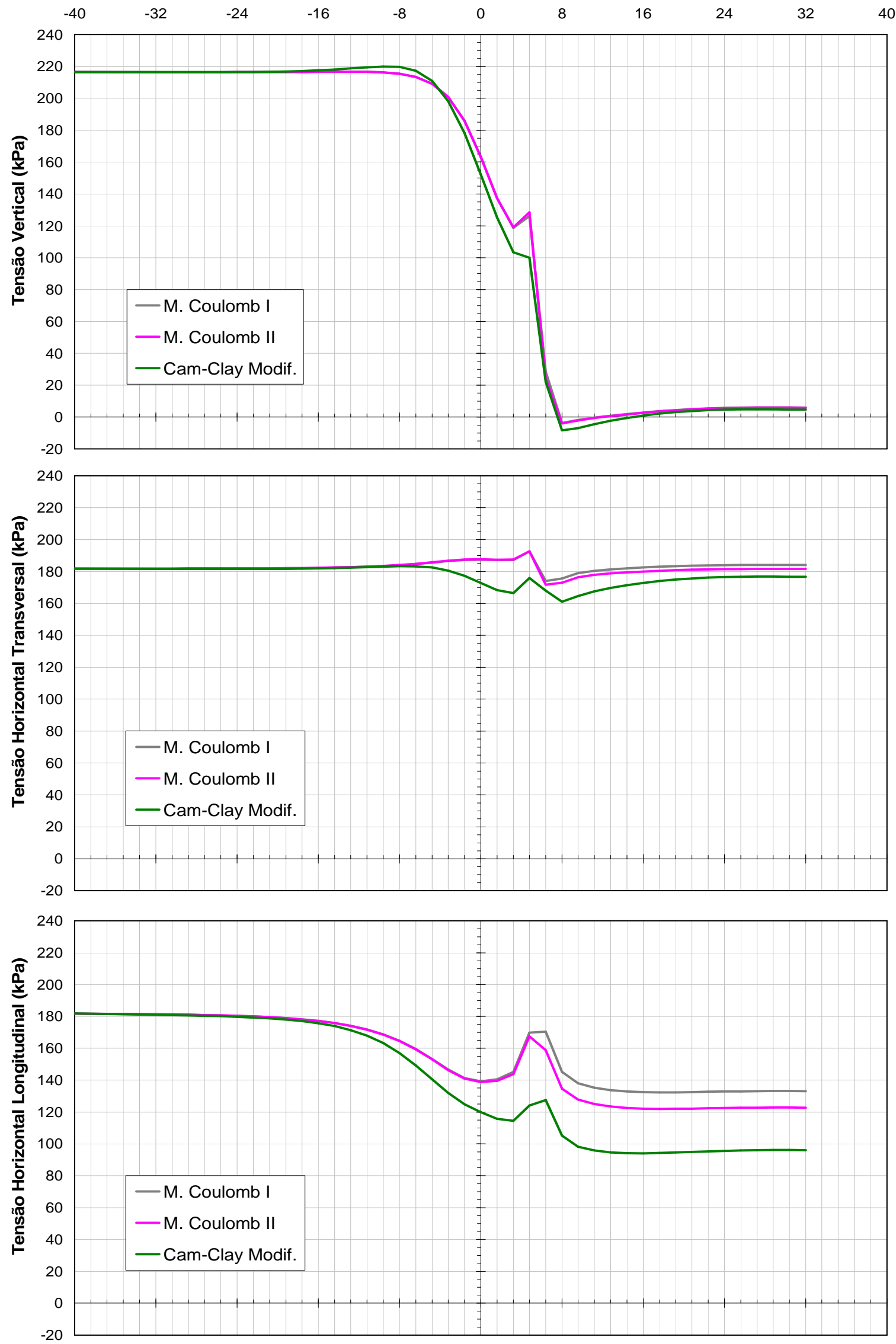

Figura 75 Tensões abaixo do túnel (ponto C). 
A observação conjunta do desenvolvimento das tensões nos pontos A, B e C e da evolução dos recalques superficiais da Figura 71 permite delimitar uma zona de influência da frente de escavação equivalente a quatro diâmetros (dois diâmetros adiante e dois diâmetros atrás da frente), uma vez que variações de tensões e/ou deslocamentos são registrados na seção instrumentada do modelo a partir do momento que a frente está a cerca de dois diâmetros dela (se aproximando), até a frente, após ter atravessado a seção, estar outros dois diâmetros afastada dela.

Para cada ponto monitorado, as análises realizadas indicaram tensões razoavelmente próximas umas das outras, com exceção da tensão vertical no ponto B (lateral do túnel, Figura 74), que nas análises com o elasto perfeitamente plástico apresentou uma tendência de ascensão com a passagem da frente pela seção instrumentada, função do arqueamento transversal, enquanto que na análise com o Cam-Clay Modificado, apresentou uma pequena queda. Talvez nesta última análise, o arqueamento longitudinal tenha sido mais importante que o transversal, o que resultou neste alívio da tensão vertical na lateral do túnel no momento da passagem da frente pela seção instrumentada.

Vale destacar o abrupto descarregamento (redução considerável da tensão vertical) na cobertura do túnel (bem junto ao eixo, no ponto A) ocorrido com a passagem da frente pela seção instrumentada, acompanhado de pequena queda e, em seguida, leve retomada das tensões horizontais transversais e longitudinais (Figura 73).

Foi realizada uma análise adicional com o Cam-Clay Modificado, desta vez bidimensional, adotando perda de volume de solo equivalente à obtida com a análise tridimensional (calculada a partir da bacia de recalques superficiais desta análise). As previsões de deslocamentos conseguidas são apresentadas nas Figuras 76 a 79. 
Distância do eixo do túnel (m)

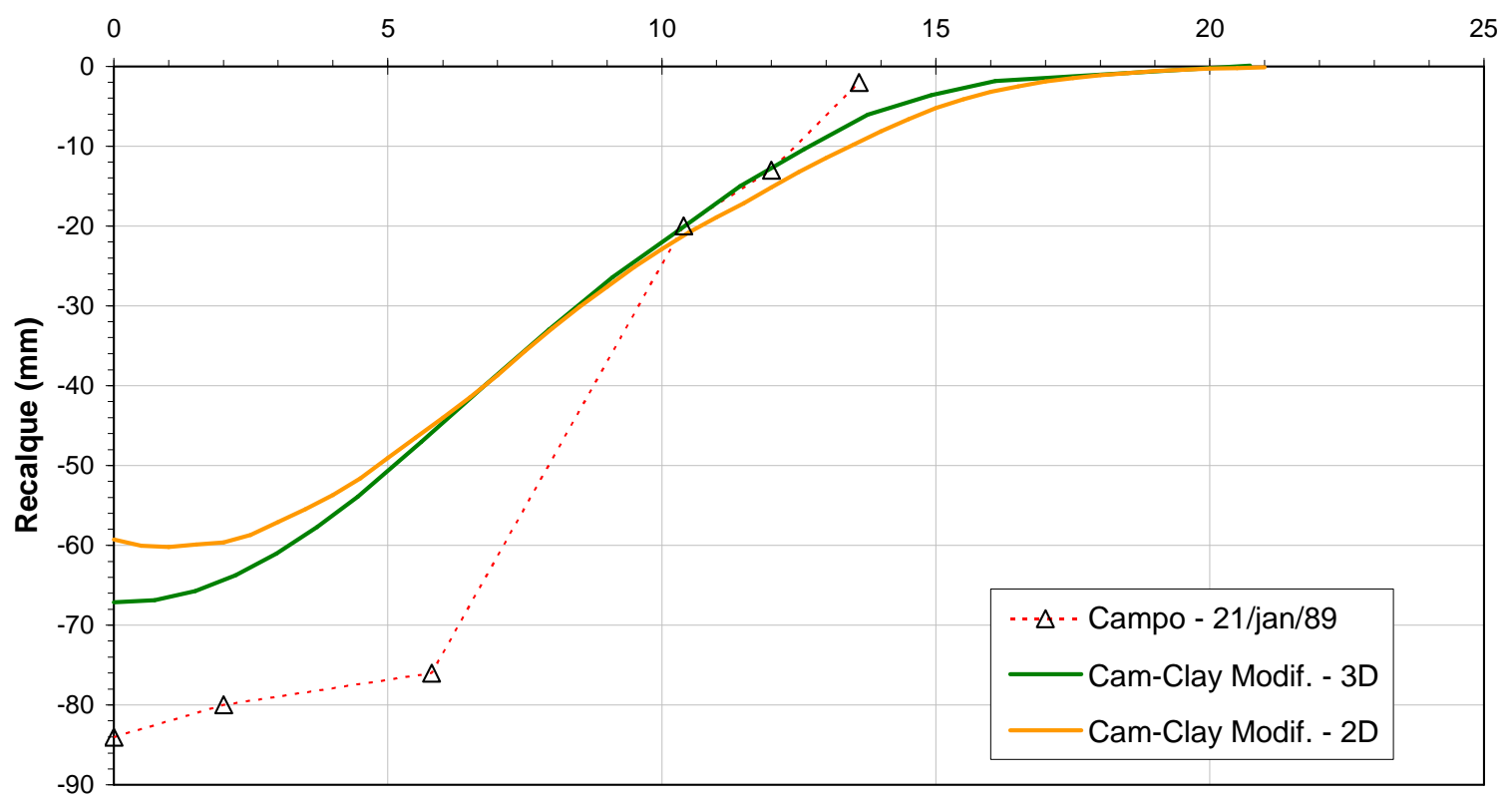

Figura 76 Bacias de recalques superficiais - análise 2D x análise 3D.

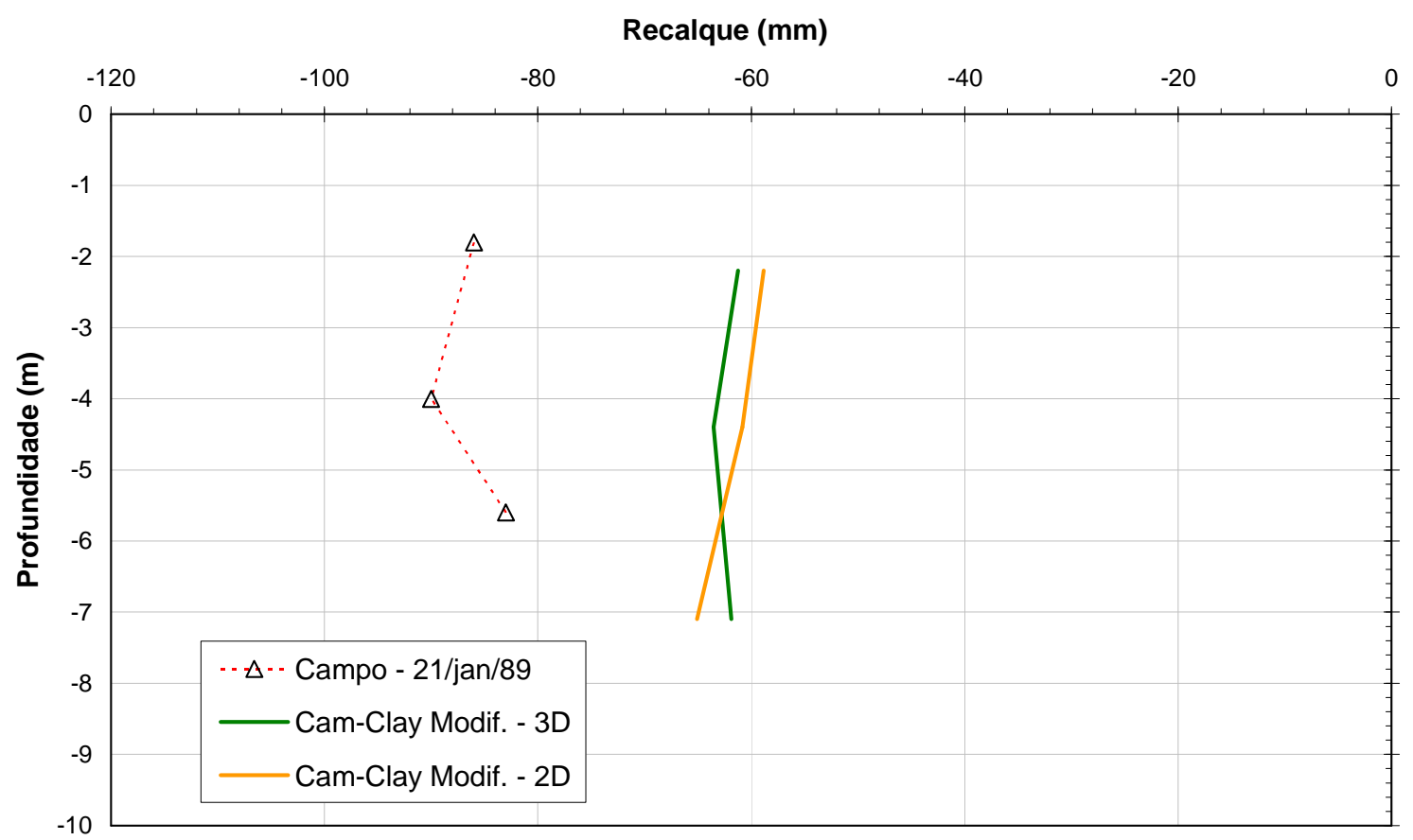

Figura 77 Recalques em profundidade - extensômetros magnéticos a $1 \mathrm{~m}$ do eixo do túnel análise 2D $\mathrm{x}$ análise 3D. 


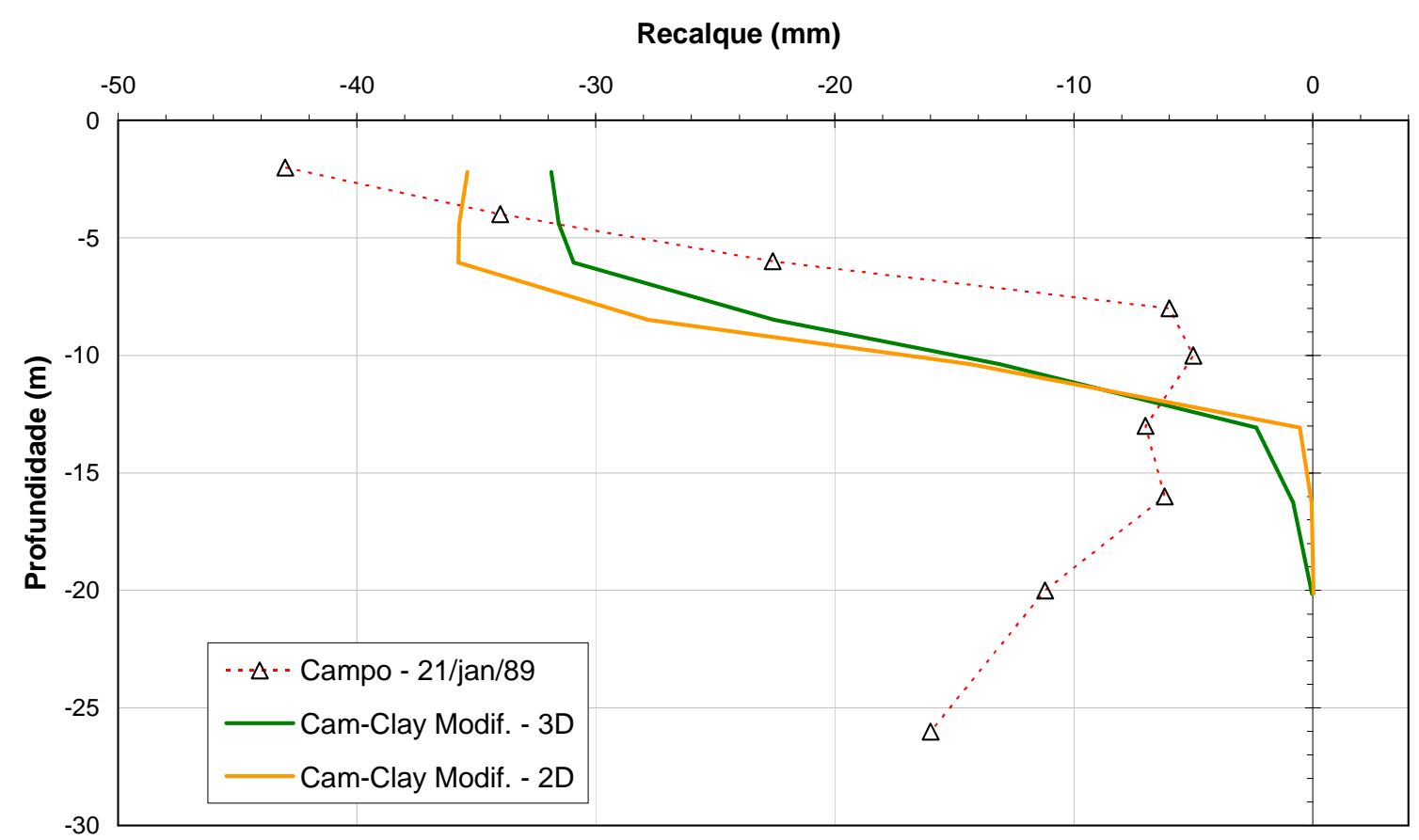

Figura 78 Recalques em profundidade - extensômetros magnéticos a $6 \mathrm{~m}$ do eixo do túnel análise 2D $\mathrm{x}$ análise 3D.

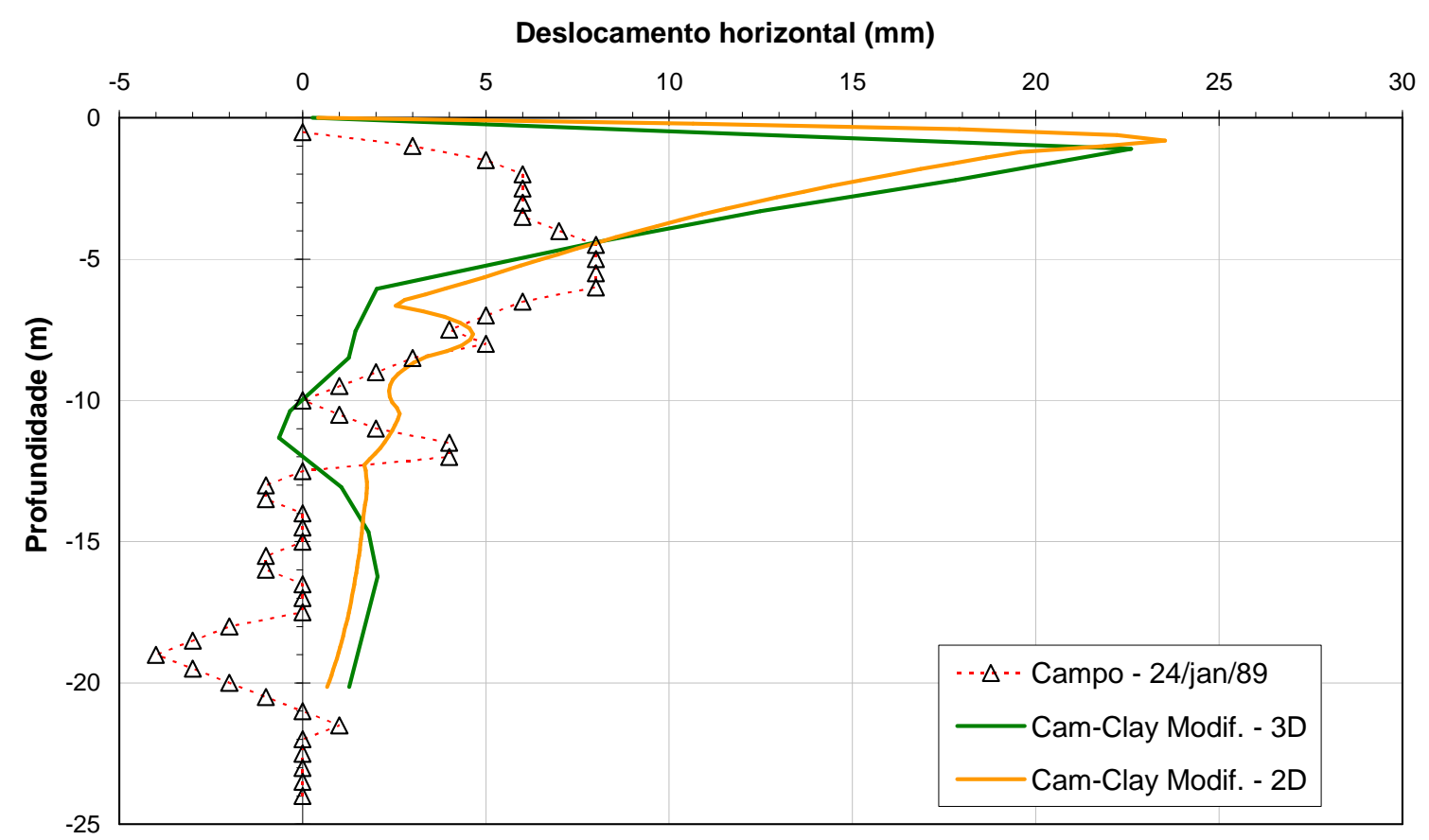

Figura 79 Deslocamentos horizontais - inclinômetro a $6 \mathrm{~m}$ do eixo do túnel - análise 2D x análise 3D. 
Os resultados conseguidos com a análise bidimensional do Cam-Clay Modificado são bem próximos aos da análise tridimensional adotando este mesmo modelo, o que sugere uma pequena influência da compressão por arqueamento longitudinal (fenômeno inexistente na análise 2D) nos deslocamentos do maciço em geral. Talvez o único impacto da não consideração deste fator na análise bidimensional seja sobre seus deslocamentos verticais em profundidade na cobertura do túnel (Figura 77), que embora próximos aos da análise 3D e aos observados em campo, são de tendência oposta a eles, sendo continuamente crescentes com a profundidade. Os deslocamentos horizontais previstos são também destoantes dos observados até a profundidade igual a $5 \mathrm{~m}$ (Figura 79).

Por fim, são apresentadas nas Figuras 80 a 83 as previsões de deslocamentos conseguidas com a análise do Cinemático com Duas Superfícies Modificado do Imperial College, bidimensional, adotando perda de volume de solo igual à perda de volume de solo real ao fim da escavação (calculada a partir da bacia de recalques superficiais fornecida pela instrumentação de campo).

Distância do eixo do túnel (m)

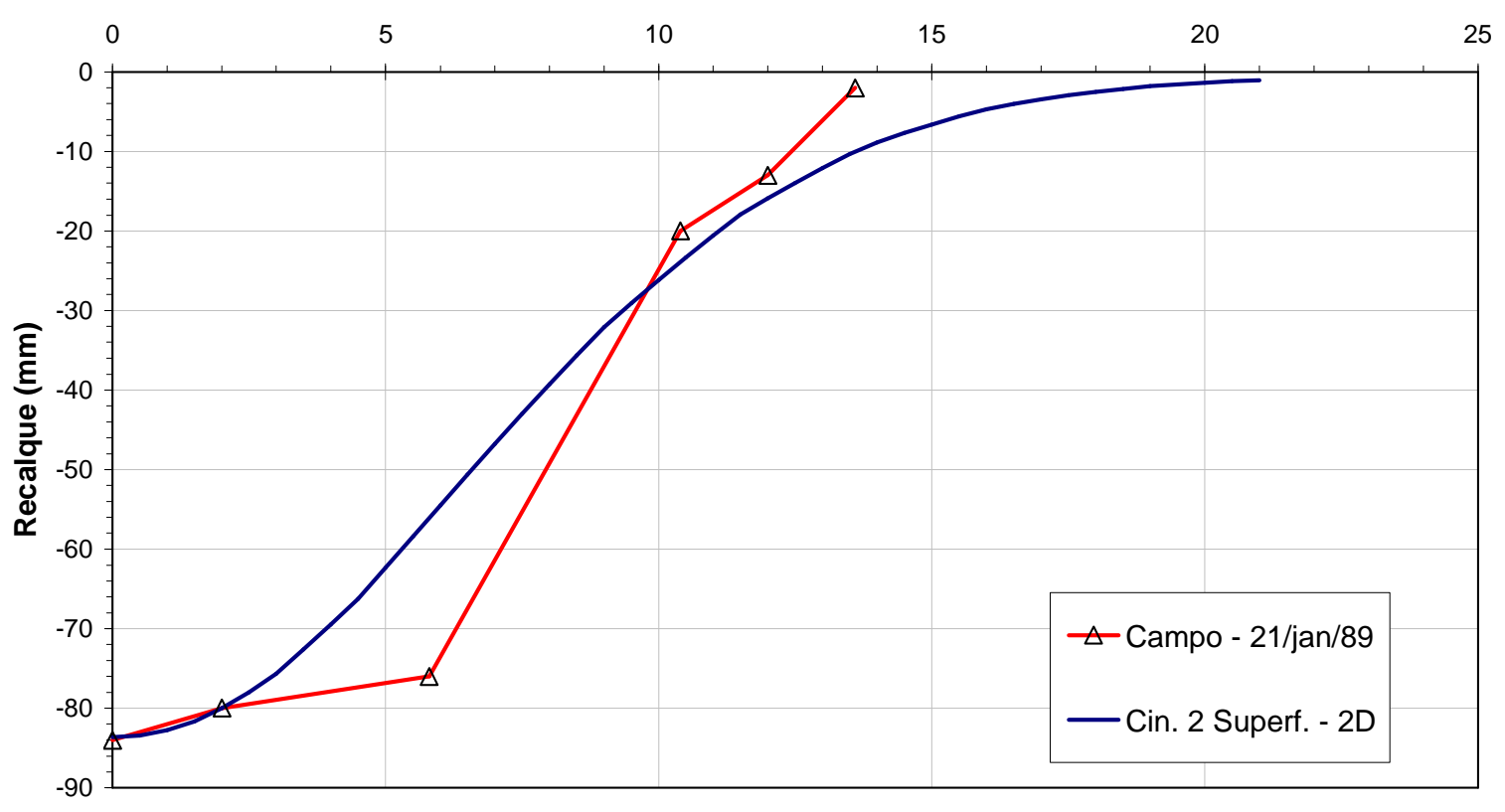

Figura 80 Bacias de recalques superficiais - análise numérica 2D x campo. 


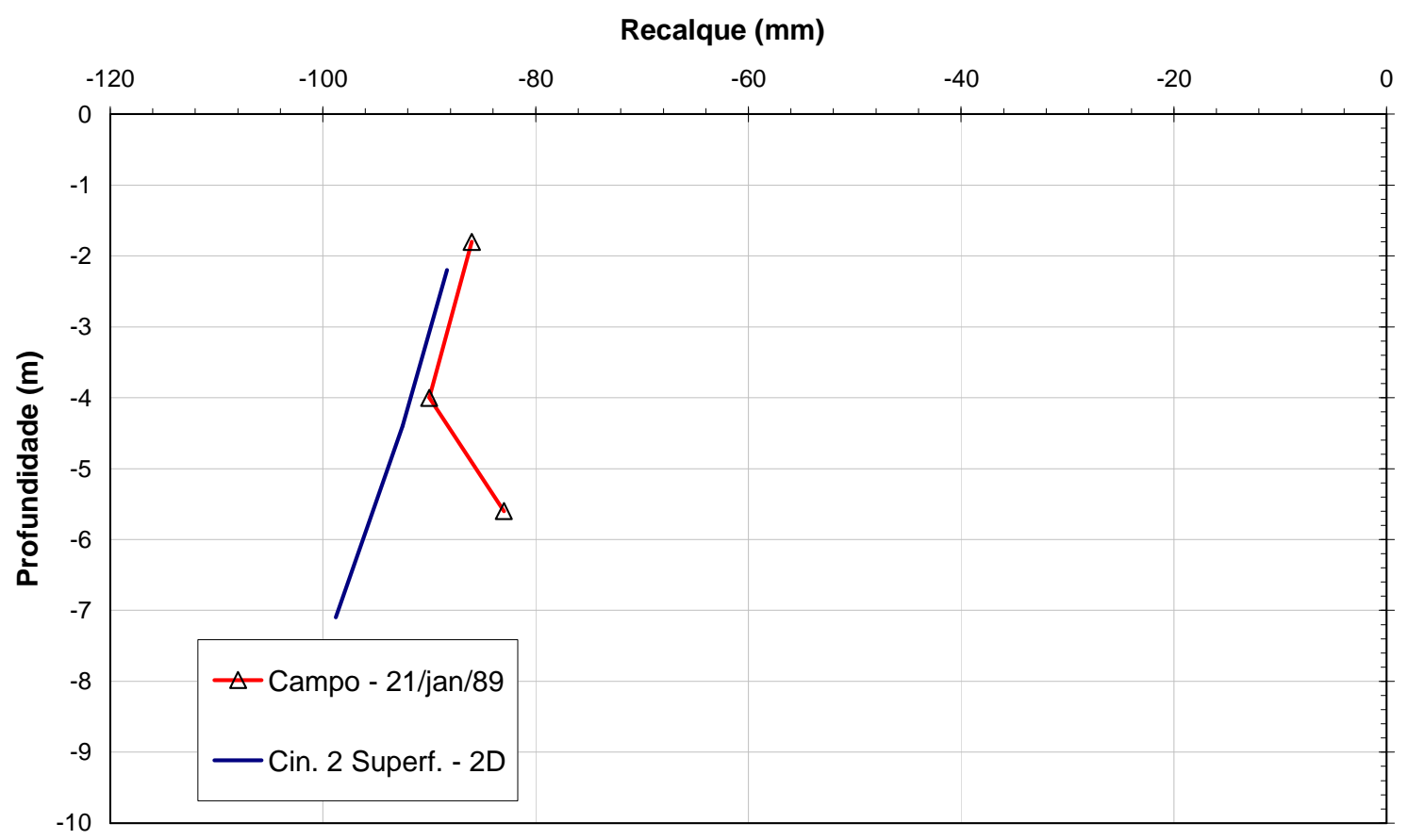

Figura 81 Recalques em profundidade - extensômetros magnéticos a 1m do eixo do túnel análise numérica $2 \mathrm{D}$ x campo.

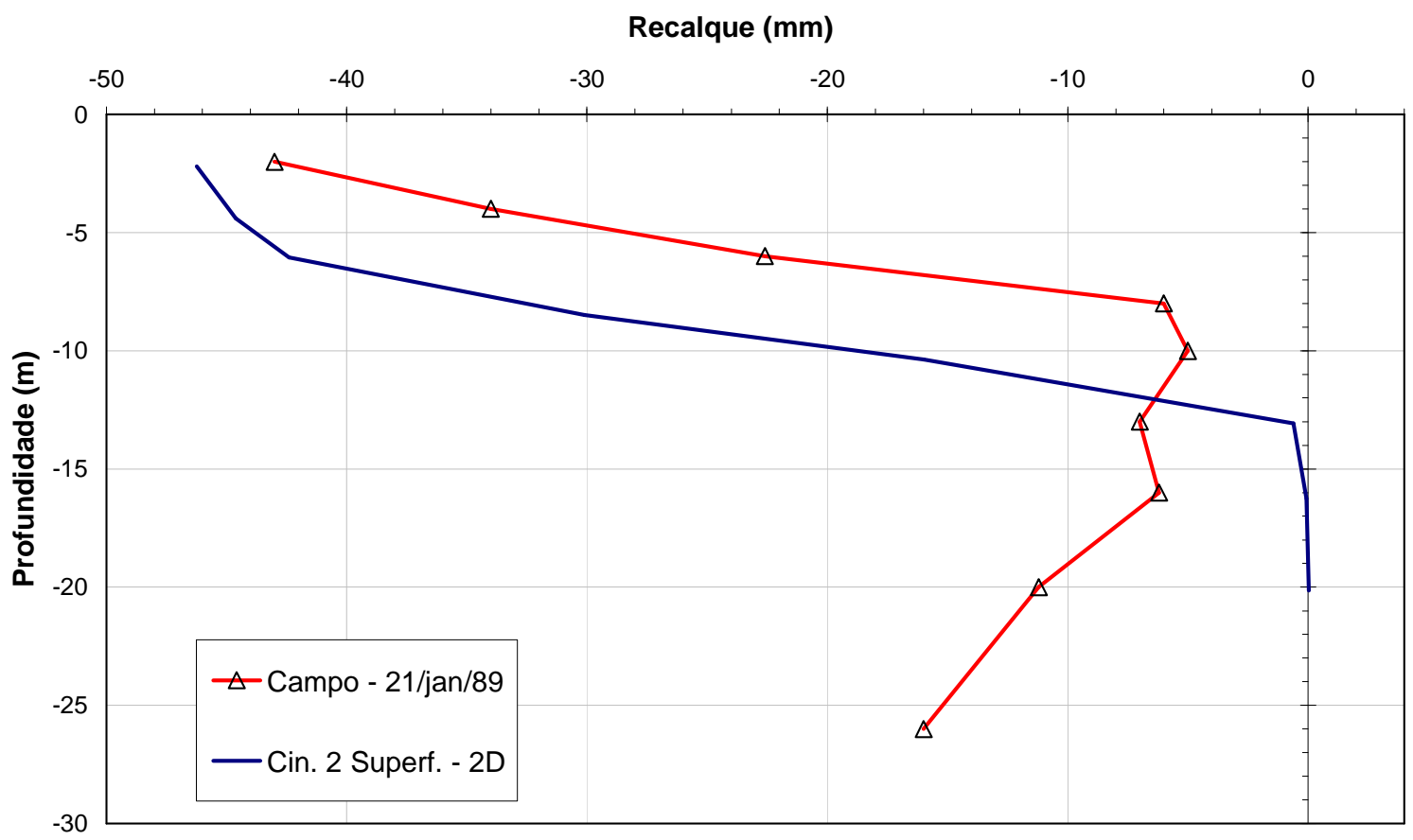

Figura 82 Recalques em profundidade - extensômetros magnéticos a 6m do eixo do túnel análise numérica 2D x campo. 


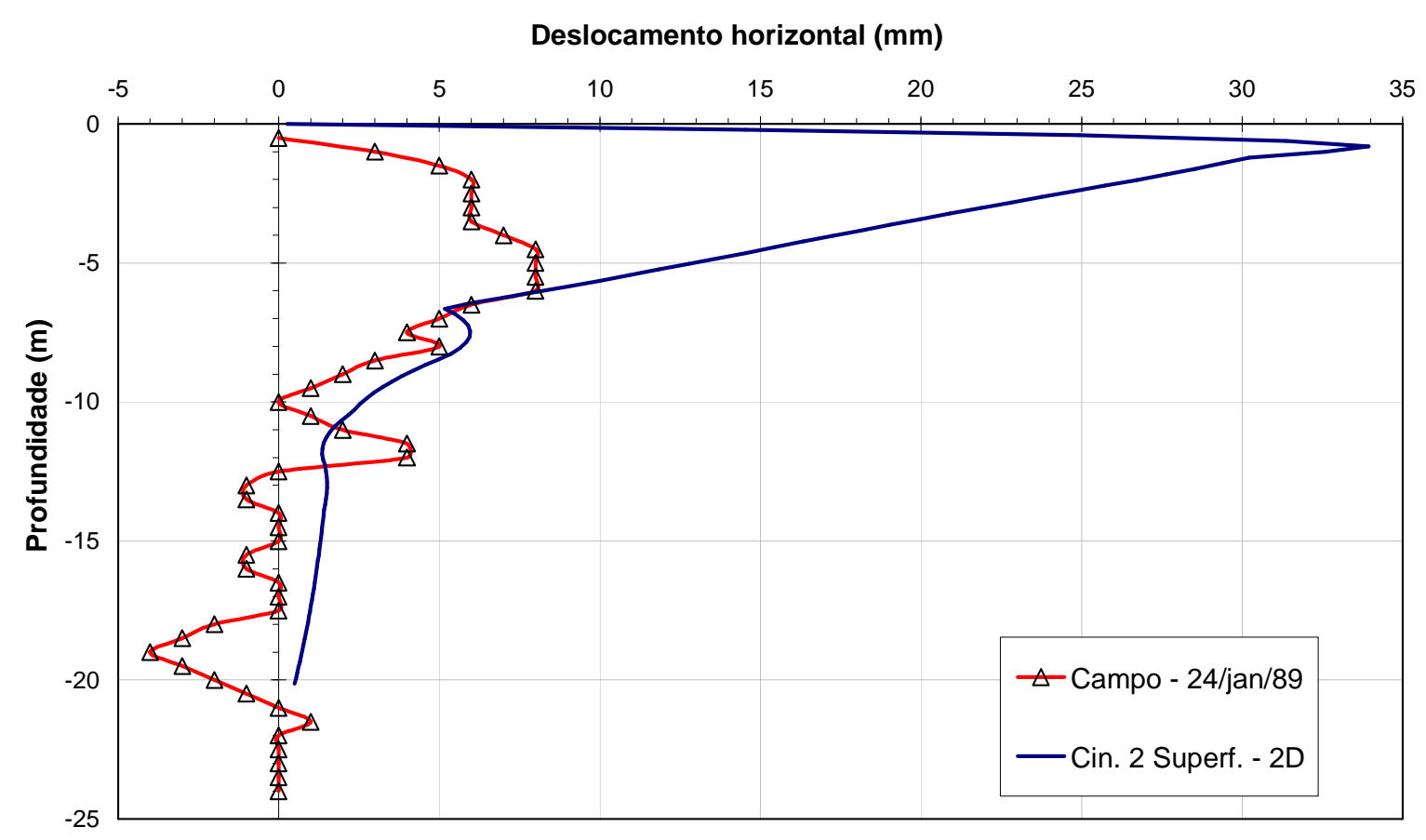

Figura 83 Deslocamentos horizontais - inclinômetro a $6 \mathrm{~m}$ do eixo do túnel - análise numérica $2 \mathrm{D}$ x campo.

Os resultados conseguidos com o Cinemático com Duas Superfícies Modificado acompanham bem os dados de instrumentação, com exceção dos deslocamentos horizontais, que destoam bastante dos observados em campo até a profundidade igual a $5 \mathrm{~m}$ (Figura 83), assim como ocorrido nas análises adotando o Cam-Clay Modificado. Os deslocamentos verticais em profundidade na cobertura do túnel previstos pelo modelo (Figura 81), embora continuamente crescentes com a profundidade, são praticamente coincidentes com os observados em campo até a profundidade igual a $4 \mathrm{~m}$. O recalque superficial máximo obtido coincidiu com o fornecido pela instrumentação, sendo a bacia em si de razoável concordância com a observada em campo (Figura 80). Fica claro, pelo apresentado acima, que uma vez conhecida a perda de volume de solo ao fim da escavação, é possível obter muito bons resultados em termos de deslocamentos verticais realizando uma análise bidimensional com o modelo Cinemático com Duas Superfícies Modificado do Imperial College. 


\section{CONSIDERAÇÕES FINAIS}

O presente trabalho de pesquisa trouxe à luz alguns estudos envolvendo modelagem numérica de escavações que representam o estado da arte em análise por elementos finitos aplicada a maciços escavados por túneis. Complementarmente, realizou modelagem numérica própria, subsidiada pela revisão dos estudos acima citados, bi e tridimensional, aplicada ao Túnel Paraíso do Metrô de São Paulo. A busca por uma ferramenta de análise tridimensional com maiores opções de modelos constitutivos levou ao período de experiência no Imperial College de Londres, onde houve contato com o ICFEP, um consagrado e abrangente programa de elementos finitos.

No ICFEP, realizou-se, primeiramente, etapa de reprodução de ensaios a fim de obtenção de parâmetros, importante para dar credibilidade às análises subseqüentes e por destacar a habilidade (ou limitação) de cada modelo constitutivo na representação do comportamento dos materiais. Em seguida, foram desenvolvidos os modelos numéricos com os quais se realizariam as análises bi e tridimensionais da escavação, adotando os modelos constitutivos elasto perfeitamente plástico, Cam-Clay Modificado e Cinemático com Duas Superfícies Modificado. Os resultados obtidos com tais análises, embora não coincidentes com os dados de instrumentação de campo (até pela impossibilidade da realização de ajustes posteriores nos modelos numéricos, em razão do tempo limitado), representaram bem o comportamento geral do maciço.

Ao fim desta pesquisa, é possível destacar alguns pontos principais:

- bom desempenho das análises tridimensionais adotando o modelo elasto perfeitamente plástico com critério de ruptura de Mohr-Coloumb na representação dos deslocamentos induzidos pela escavação, especialmente da análise que considerou valores de ângulo de dilatância negativos (associados a uma melhor reprodução dos ensaios triaxiais);

- representação da tendência peculiar dos deslocamentos em profundidade na cobertura do túnel por parte da análise tridimensional adotando o Cam-Clay Modificado. As análises 2D realizadas, apesar de adotarem modelos com capacidade de considerar rigidezes distintas para 
as situações de carregamento e descarregamento (Cam-Clay Modificado e Cinemático com Duas Superfícies Modificado), não conseguem reproduzir tal tendência, uma vez que não contemplam pré-compressão por arqueamento longitudinal;

- desempenho ruim dos modelos baseados no estado crítico na previsão dos deslocamentos horizontais, independente do tipo de análise realizada (se bi ou tridimensional);

- muito bom desempenho da análise bidimensional adotando o Cinemático com Duas Superfícies Modificado na previsão dos deslocamentos verticais, atrelado, no entanto, ao conhecimento prévio da perda de volume de solo ao final da escavação;

- hipótese do efeito da elevada rigidez inicial da estrutura de suporte do modelo numérico: o valor adotado para a rigidez inicial do concreto projetado, igual a $3 \mathrm{GPa}$ (aproximadamente a média entre 0,6 e 5GPa, valores utilizados respectivamente por Sousa (1998) e França (2006)), seria ainda alto e, por isto, houve restrição de deslocamentos verticais no maciço.

\subsection{SUGESTÕES PARA TRABALHOS FUTUROS}

Para trabalhos de pesquisa futuros, é possível apontar alguns temas interessantes relacionados à modelagem numérica de escavações de túneis:

- análise por elementos finitos aplicada a escavações com tuneladoras, visto que a demanda por este método construtivo, reconhecidamente mais veloz e com maior controle da perda de volume de solo, deve aumentar no país, em razão da necessidade de se expandir a infraestrutura nacional em curto prazo (visto a realização de eventos como a Copa do Mundo e os Jogos Olímpicos respectivamente em 2014 e 2016);

- modelagem numérica de escavações considerando as estruturas existentes na superfície, a fim de que se avalie a influência da rigidez destas estruturas nos deslocamentos induzidos pelo tunelamento; 
- com relação a escavações adotando processo construtivo baseado no NATM, análise numérica tridimensional considerando um realístico aumento da rigidez do concreto projetado a partir do momento em que ele é instalado (aumento gradual, partindo de valores bem baixos, associado à variável tempo e ao avanço da escavação), visto que os modelos numéricos 3D que adotam valores de rigidez médios ou que realizam variação simplificada da rigidez desta estrutura de suporte (como faz o modelo desenvolvido neste trabalho) podem subestimar, independente do modelo constitutivo empregado, os deslocamentos induzidos pela escavação;

- modelagem numérica investigando o impacto de novas escavações sobre túneis existentes vizinhos, fazendo uso de dados de monitoramentos eventualmente realizados em túneis existentes quando da escavação de um novo trecho nas proximidades;

- desenvolvimento de um programa de elementos finitos voltado à análise de obras geotécnicas, ainda que simples, mas que possa servir de base e ser implementado por estudos posteriores;

- por fim, recomenda-se uma maior exploração do caso do Túnel Paraíso, através da realização de análises por elementos finitos adotando outros modelos constitutivos e numéricos, sempre precedidas por etapa de reprodução dos ensaios disponíveis. 


\section{REFERÊNCIAS BIBLIOGRÁFICAS}

AL-TABBAA, A. (1987). Permeability and Stress-Strain Response of Speswhite Kaolin. $\mathrm{PhD}$ Thesis, University of Cambridge, Cambridge, UK.

CECÍLIO JR., M.O. (2009). Estudo do Comportamento de Um Túnel em Solo Residual de Gnaisse por Meio de Ensaios Triaxiais com Controle de Trajetória de Tensões. Dissertação de Mestrado, Escola Politécnica da Universidade de São Paulo, 204p.

FRANÇA, P.T. (2006). Estudo do Comportamento de Túneis. Análise Numérica Tridimensional com Modelos Elasto-Plásticos. Dissertação de Mestrado, Escola Politécnica da Universidade de São Paulo, 185p.

FRANZIUS, J.N.; POTTS D.M. (2005). Influence of the Mesh Geometry on ThreeDimensional Finite-Element Analysis of Tunnel Excavation. International Journal of Geomechanics, Vol. 5, No. 3, p.256-266.

GRAMMATIKOPOULOU, A. (2004). Development, Implementation and Application of Kinematic Hardening Models for Overconsolidated Clays. PhD Thesis, Imperial College, University of London, London, UK.

GRAMMATIKOPOULOU, A.; ZDRAVKOVIC, L.; POTTS, D.M. (2008). The Influence of Previous Stress History and Stress Path Direction on the Surface Settlement Trough Induced by Tunnelling. Géotechnique, 58 (4) p.269-281.

KATZENBACH, R.; BRETH, H. (1981). Nonlinear 3D Analysis for NATM in Frankfurt Clay. Proc. $10^{\text {th }}$ Int. Conf. Soil Mechanics and Foundation Engineering, Vol. 1, Balkema, Rotterdam, p.315-318. 
MAIR, R.J.; TAYLOR, R.N.; BRACEGIRDLE, A. (1993). Subsurface Settlement Profiles Above Tunnels in Clays. Géotechnique, 43 (2) p.315-320.

MARQUES, F.E.R. (2006). Comportamento de Túneis Superficiais Escavados em Solos Porosos. O Caso do Metrô de Brasília/DF. Tese de Doutorado, Departamento de Engenharia Civil, Faculdade de Ciências e Tecnologia da Universidade de Coimbra, 462p.

MASSAD, F. (1974). Características Geotécnicas das Argilas Porosas Vermelhas de São Paulo. In Anais do V Congresso Brasileiro de Mecânica dos Solos, São Paulo, Vol. 2, p.131144.

PARREIRA, A.B. (1991). Análise de Túneis Rasos em Solo - O Túnel Mineiro Paraíso da Linha Paulista do Metropolitano da Cidade de São Paulo. Tese de Doutorado, Departamento de Engenharia Civil da PUC-Rio, Vol. 1 e 2, 298p.

POTTS, D.M.; ZDRAVKOVIC, L. (1999). Finite Element Analysis in Geotechnical Engineering: Theory, Thomas Telford, London.

ROSCOE, K.H.; BURLAND, J.B. (1968). On the Generalised Stress-Strain Behaviour of 'Wet' Clay. Engineering Plasticity, Cambridge University Press, pp.535-609.

SILVA, M.A.A.P. (2008). Simulações Numéricas para Escavações Subterrâneas. Dissertação de Mestrado, Instituto Tecnológico de Aeronáutica, São José dos Campos, 133p.

SOUSA, J.N.V.A. (1998). Túneis em Maciços Terrosos. Comportamento e Modelação Numérica. Tese de Doutorado, Universidade de Coimbra, 623p. 
SOUSA, J.N.V.A.; NEGRO, A.; MATOS FERNANDES, M., CARDOSO, A.S. (2011). Three-Dimensional Nonlinear Analyses of a Metro Tunnel in São Paulo Porous Clay, Brazil. Journal of Geotechnical and Geoenvironmental Engineering, Vol. 137, No. 4, p.376384. 